WORKING PAPER

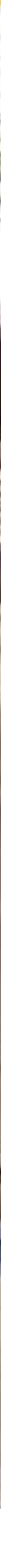

\title{
The bamboo production to consumption system in Cameroon
}

Verina Ingram

Julius Chupezi Tieguhong

Eric Maturin Nkamgnia

Jean Paul Eyebe

Mathew Ngawel 



\title{
The bamboo production to consumption system in Cameroon
}

\author{
Verina Ingram \\ Julius Chupezi Tieguhong \\ Eric Maturin Nkamgnia \\ Jean Paul Eyebe \\ Mathew Ngawel
}


Working Paper 50

(c) 2010 Center for International Forestry Research

All rights reserved

Photos: Verina Ingram, Julius Chupezi Tieguhong, Ilse Pelkmans, Martin Lieber, Katrin Ingram

Ingram, V., Tieguhong, J.C., Nkamgnia, E.M., Eyebe, J.P. and Ngawe, M. 2010 Bamboo production to consumption system, Cameroon. CIFOR, Bogor, Indonesia

\author{
CIFOR \\ Jl. CIFOR, Situ Gede \\ Bogor Barat 16115 \\ Indonesia \\ T +62 (251) 8622-622 \\ F +62 (251) 8622-100 \\ E cifor@cgiar.org
}

\title{
www.cifor.cgiar.org
}

Any views expressed in this publication are those of the authors. They do not necessarily represent the views of CIFOR, the authors' institutions or the financial sponsors of this publication.

This study was financed by the International Network for Bamboo and Rattan (INBAR) as part of a Common Fund for Commodities project 'Enhancing Opportunities for Market-Led Bamboo and Rattan-based Development in West and Central Africa'. A presentation of initial results was made at the International workshop in Yaoundé, Cameroon, 23-25 November 2009, organised by the (INBAR, the World Agroforestry Centre (ICRAF) and the Ministry of Forests and Wildlife of the government of Cameroon. 


\section{Contents}

INBAR's bamboo and rattan development programme vi

Abbreviations

Acknowledgements

Summary

viii

1. Introduction

Objectives

Rationale for the study

Background to Cameroon

Review of bamboo sector in Cameroon

$\begin{array}{ll}\text { Markets } & 15\end{array}$

2. Methodology $r$

$\begin{array}{ll}\text { Definition of the Production to Consumption System } & 19\end{array}$

$\begin{array}{lr}\text { Study areas } & 19\end{array}$

$\begin{array}{lr}\text { Data collection parameters } & 20\end{array}$

$\begin{array}{ll}\text { Sampling techniques } & 21\end{array}$

\begin{tabular}{lr}
3. & Results \\
\hline
\end{tabular}

$\begin{array}{lr}\text { Overview of the PCS } & 23\end{array}$

$\begin{array}{lr}\text { Actors } & 23\end{array}$

$\begin{array}{lr}\text { Location of production and consumption zones } & 24\end{array}$

$\begin{array}{lr}\text { Trade circuits } & 24\end{array}$

$\begin{array}{lr}\text { Processing } & 24\end{array}$

$\begin{array}{lr}\text { Stakeholders } & 30\end{array}$

$\begin{array}{lr}\text { Actors in the PCS } & 33\end{array}$

$\begin{array}{lr}\text { Bamboo harvesters } & 33\end{array}$

$\begin{array}{ll}\text { Description of the bamboo harvest system } & 33\end{array}$

$\begin{array}{lr}\text { Processors } & 38\end{array}$

$\begin{array}{lr}\text { Bamboo traders } & 45\end{array}$

$\begin{array}{lr}\text { Consumers } & 50\end{array}$

4. Development of the bamboo sector in Cameroon $\quad 51$

Problems, constraints and opportunities in the bamboo sector $\quad 51$

5. Policy and institutional framework for the bamboo sector 55

$\begin{array}{lr}\text { Policy environment } & 55\end{array}$

$\begin{array}{ll}\text { Regulations } & 55\end{array}$

$\begin{array}{ll}\text { Customary rules } & 55\end{array}$

$\begin{array}{ll}\text { Institutional and administrative framework } & 57\end{array}$

6. Development opportunities and ways forward $\quad 59$

$\begin{array}{lr}\text { Developing the Cameroon bamboo sector } & 59\end{array}$

$\begin{array}{lr}\text { Recommendations } & 59\end{array}$

$\begin{array}{ll}\text { References } & 63\end{array}$

$\begin{array}{lr}\text { Appendices } & 67\end{array}$

$\begin{array}{ll}\text { Appendix 1. List of actor and stakeholder interviews } & 67\end{array}$

$\begin{array}{ll}\text { Appendix 2. Questionnaires } & 71\end{array}$

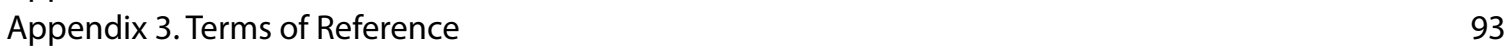




\section{Tables}

1. Cameroon Human Development Indices 3

2. Cameroon forest key figures $\quad 4$

3. Bamboo species in Cameroon 6

4. World bamboo and rattan export and imports $\quad 16$

5. Bamboo PCS actors interviewed $\quad 21$

6. Geographic location of bamboo production, processing and consumption in Cameroon 26

\begin{tabular}{ll}
7. & Education level of harvesters \\
\hline
\end{tabular}

8. Socio-economic profile of harvesters $\quad 36$

9. Ownership status of bamboo stands per region $\quad 36$

$\begin{array}{ll}\text { 10. Types of harvesters associations and objectives } & 37\end{array}$

\begin{tabular}{ll} 
11. & Quantity of stems harvested per year and species \\
\hline 12. & 38
\end{tabular}

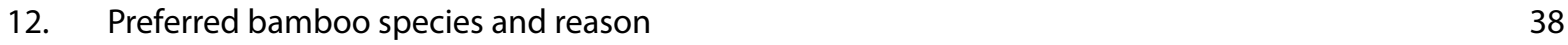

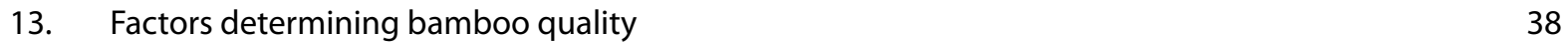

$\begin{array}{lr}\text { 14. Income sources for bamboo harvesters } & 40\end{array}$

15. Harvesters' expenditure $\quad 40$

16. Distribution of bamboo processors by region 40

17. Income generation sources for bamboo processors 41

18. Processors' associations $\quad 42$

19. Objectives of processors associations $\quad 42$

20. Derived/expected benefit from associations $\quad 42$

21. Bamboo products and species $\quad 43$

22. Price determinants for processed bamboo 443

23. Processors' annual sources of household income 43

24. Income from different bamboo products 43

25. Processors' expenditures $\quad 44$

26. Processors raw material costs $\quad 44$

27. Processors' equipment costs $\quad 44$

28. Processors' miscellaneous costs $\quad 44$

29. Processors' household expenses $\quad 46$

30. Traders associations in Cameroon $\quad 46$

31. Objectives of traders associations $\quad 46$

32. Proportion of traders and bamboo products 4

33. $\quad$ Bamboo products and markets $\quad 48$

$\begin{array}{lr}\text { 34. Product price determinants } & 48\end{array}$

35. Traders' preferred species and reasons $\quad 48$

36. Trader's income sources $\quad 48$

37. Expenses incurred by bamboo traders $\quad 49$

38. Uses of bamboo per region $\quad 49$

39. Quality comparison of bamboo vs. other products 50

40. Consumer ranking of potentially interesting bamboo products 50

41. Problems faced by bamboo processors $\quad 52$

42. Problems and practical solutions $\quad 52$

43. Legal and regulatory issues and recommendations $\quad 56$ 


\title{
Figures
}

1. Raphia mambilenses or Indian bamboo 5

2. Stratification of Kilum ljum forest, NW Cameroon 10

3. Yushina alpina groves in Kilum ljum forest, Northwest 10

4. Bambusa vulgaris $r 11$

5. Yushaniaalpina $r$

6. Oxytenanthera abyssinica $r$

7. Ochlandra travancorica $r$

8. Bambusa vulgaris vitatta 12

9. Oxytenanthera abyssinica $\quad 13$

11. Bambusa vulgaris 13

10. Yushania alpina 13

12. Global bamboo and rattan export and import market shares 1989-2007 17

13. Bamboo market trader Yushina alpina storage 'jars', Oku, Northwest 17

14. Bamboo (Bambusa vulgaris), Korup, Southwest 19

15. Map of main bamboo harvesting areas in Cameroon $\quad 20$

16. The bamboo PCS in Cameroon $\quad 23$

17. Bamboo (Bambusa vulgaris), Yaoundé-Edea road 24

18. Major bamboo production zones in Cameroon $\quad 25$

19. Major bamboo production zones in the Northwest region $\quad 25$

$\begin{array}{lr}\text { 20. Major trade circuits } & 30\end{array}$

21. Bamboo herb drying rack, Babungo, Northwest $\quad 30$

22. Bamboo processing in Cameroon $\quad 31$

23. Bamboo and mud wall, Oku, Northwest $\quad 31$

24. Traditional bamboo spear, Oku, Northwest $\quad 31$

25. Bamboo clad restaurant and furniture, Buea, Southwest 32

27. Frequency of bamboo product types/uses in Cameroon 32

28. Bamboo based paper making process, Oku, Northwest 32

26. Bamboo and rattan chairs, Douala, Littoral $\quad 32$

29. Stakeholders in the bamboo PCS Cameroon $\quad 33$

30. Sources of income for bamboo harvesters $\quad 35$

31. Stated profession of bamboo harvesters $\quad 35$

\begin{tabular}{ll} 
32. & Land ownership status \\
\hline
\end{tabular}

33. Samples of bamboo species found in Cameroon $\quad 38$

34. Determinants of quantity of bamboo harvested $\quad 39$

35. Motivation to enter bamboo processing 41

36. Bamboo and rattan processor craftsmen, Yaoundé 4

37. Bamboo traders' major income sources $\quad 47$

38. Minor income sources for bamboo traders $\quad 47$

39. Roadside bamboo furniture marketing, near Mbalmayo 50

40. Problems faced by bamboo harvesters $r$

41. Constraints faced by traders $\quad 53$

42. Solutions to problems faced by traders $\quad 53$

43. Development opportunities proposed by actors $\quad 59$

\section{Exchange rates}

\author{
At September $2009 \quad 1.00$ Euro $=655.957$ CFAF $/ \quad 1$ CFAF $=0.00152449$ EUR \\ 1.00 USD $=441.192 \mathrm{CFAF} / \quad 1 \mathrm{CFAF}=0.00226658 \mathrm{USD}$
}




\section{INBAR's bamboo and rattan development programme}

This study is part of the INBAR and World Agroforestry Centre project 'Enhancing opportunities for market-led bamboo-based development in West and Central Africa' from 2008-2009, financed by the Common Fund for Commodities. The project produced studies of the bamboo Production to Consumption Systems in Ghana and Togo, Cameroon, Nigeria and Sierra Leone. The findings were presented at a regional workshop in Yaoundé, 23-25 November 2009, to develop national and regional actionable recommendations for market-led, bamboo-based development in the region.

The application of bamboo and rattan in enhancing the economic and ecological wellbeing of resourcedependent communities in Asia has been extensive. Systematic studies of the potential of bamboo and rattan, previous and current uses, and the social, cultural and political perspectives of these resources have been invaluable in promoting their development through innovative and sustainable use. The International Network for Bamboo and Rattan (INBAR) plays a pivotal role in advancing the bamboo and rattan sector and has facilitated and coordinated research (including action-research) on biodiversity and genetic conservation, production systems, processing and utilisation and socio-economic and policy, while promoting capacity building at the national level. A number of rural development programs are being implemented in the region. INBAR has also been instrumental in promoting technology transfer and information exchange between network partners. The replicability of the successful commoditisation of bamboo and rattan in South and Southeast Asia, Latin America and Africa is yet to be assessed, despite the immense interest from the private sector, non-governmental organisations and government institutions in using bamboo and rattan to fuel rural development in the region. The dearth of information has been one of the main constraints on developing systematic and sustainable development programmes in this sector.

To do this, INBAR has commissioned national studies from selected countries in Africa and Central and South America. These national studies provide a thorough review of the current state and future potential of the bamboo and rattan sectors in each country. Certain standard indicators are documented to allow regional comparisons while other information will be country- specific. The national studies will help the experts decide the priority areas for study at local, national and regional levels. This in turn will help INBAR clearly define its role within these countries as a facilitator and coordinator.

INBAR has developed an outline for these national studies, to which this study conforms. The outline serves two purposes. Firstly, it is meant to facilitate the data collection process and, secondly, it should assist in formulating case study reports. The framework also guarantees that comparable information is provided in each national study. Information covered includes: general information on the country (geographical, topographical, climate, demography, political, environmental); the bamboo and rattan sector (biodiversity, production, utilisation, socio-economics, marketing, legislation); the institutional capacity at the national and local level; previous, ongoing and upcoming research and development interventions in the bamboo and rattan sector; and, finally, conclusions and recommendations.

After defining priority areas, case studies are undertaken in a number of carefully chosen, highly representative, locations within the country to collect raw data on all aspects of the present state of the bamboo and/or rattan sectors. The case studies investigate the Production to Consumption System; this involves the entire chain of activities, from the production of raw materials (including the input market, where one exists) through the various stages of intermediate sales and processing, to the consumer of the final product. The system includes the technologies used to process the material as well as the social, political and economic environments in which these processes operate.

After the raw data has been collected, it is analysed and classified into two focus areas: constraints and opportunities. Potential options to address the constraints or take advantage of the opportunities and thereby promote development are identified, and development plan formulated. This plan can then be developed into an action-research project, which is actually a micro- or mini-level rural development project. It effectively can be a trial project, and is intended both to test whether the interventions suggested by the study are appropriate and to obtain feedback from the local population on all aspects of 
the programme. The methodology and development options (interventions) of these projects would be finalised at a stakeholders meeting in the country before to the project starts.

If an impact analysis study at the end of the actionresearch project indicates that the project is successful, and the community agrees, this would then form the basis for developing similar programs that could be expanded in scope and applied in similar situations throughout the region or nation. In this way we go in a short time from a fully tested, small-scale trial project to multiple projects with considerable impact. At the national or regional level, these programmes could attract investment from donors interested in poverty alleviation and rural development. 


\title{
Abbreviations
}

\author{
ANAFOR \\ National Office of Reforestation \\ CIFOR \\ CFC \\ Center for International Forestry Research \\ CFAF \\ FAO \\ Common Commodity Fund \\ African Financial Community Franc (Franc de la Communauté Financière Africaine) \\ ICRAF \\ INBAR \\ MINADER \\ MinFoF \\ Food and Agriculture Organization of the United Nations \\ World Agroforestry Centre \\ International Network for Bamboo and Rattan \\ MINPME \\ Ministry of Agriculture and Rural Development \\ Ministry of Forestry and Wildlife \\ Ministry of Small and Medium Enterprises \\ MOCAP \\ NTFP \\ Mount Cameroon Prunus africana Harvesting Company \\ PCS \\ Non-timber forest products \\ REDD \\ production to consumption system \\ TTRECED \\ Reduced emissions from deforestation and degradation \\ Technical Training and Research Centre for Development
}




\section{Acknowledgements}

Many people and organisations contributed to this report by providing literature, insightful discussions and comments. From CIFOR, we thank Terry Sunderland, Jolien Schure, Patrice Levang, Nick Hogarth, Abdon Awono and CIFOR Associate Manuel Ruiz-Pérez for reviewing the final report. We are also grateful to ANAFOR, particularly Désiré Tole; the Ministry of Forests and Wildlife, especially Paul Wamba; Ousseynou Ndoye at the FAO, Tropenbos International, MOCAP, Ferrudjal, and especially the bamboo enterprises, village chiefs, individual bamboo collectors, processors, traders and consumers who participated in this study. Many thanks also to INBAR for entrusting us with this study, and especially to Andrew Bennett and Micheal Kwakar for their support. We are grateful to the photographers for making available their photographs and their assistance in the field.

This study was financed by INBAR as part of a Common Fund for Commodities project "Enhancing Opportunities for Market-Led Bamboo and Rattan-based Development in West and Central Africa'. 


\section{Summary}

Few data are currently available about bamboo production, processing and consumption in Cameroon. Baseline information is, however, critical to inform policymakers and practitioners, and guide decision-making on how to manage the development and implementation of interventions in the bamboo 'chain' from harvest though production, transformation, marketing and consumption of bamboo-based products. Therefore, as part of the International Network for Bamboo and Rattan's (INBAR) efforts to promote research, technology transfer, exchange of information and capacity building in the bamboo sector globally and in the framework of the "Enhancing opportunities for market-led bamboo-based development in West and Central Africa program', CIFOR conducted a Production to Consumption System (PCS) study of bamboo in Cameroon between September 2009 and February 2010.

This study reviewed the current state of Cameroon's bamboo sector and the potential for development, taking a market-led perspective. The methodology involved first conducting a literature review and gathering general information on the country (geographical, topographical, climate, demography, political, environmental); the bamboo sector (biodiversity, production, utilisation, socioeconomics, marketing, legislation); national and local institutional capacity; and, previous, ongoing and upcoming bamboo research and development interventions. To that end, 112 stakeholders were interviewed to verify the literature, understand the bamboo market chain and identify the main production areas and markets. Interviews were conducted with 149 harvesters, processors, traders and consumers in five regions (West, Northwest, Southwest, Littoral and Centre) of Cameroon. These data were entered into a statistical package and analysed. Additional data was collected in the East and Adamaoua regions and preliminary species identification was undertaken.

The study results indicate that although Cameroon has two bamboo species indigenous to Africa (the alpine bamboo Yushina alpina and savannah bamboo Oxytenanthera abyssinica), largely introduced, exotic varieties are used, particularly 'Chinese bamboo' (Bambusa vulgaris). These species were most probably introduced during colonial times around watercourses and settlements. The exception is the mountain forests of the Northwest, where an estimated 500 $\mathrm{km}^{2}$ of Yushina alpina forest exists, which is used in 12 different ways, mainly locally around Oku, Belo and Fundong.

The PCS market chain consists of four types of stakeholders, with active actors being largely individual or micro and small enterprises of owners, collectors and harvesters; processer craftspersons; traders and retailers; and, consumers. Regulatory, support and control actors, such as local and central government ministries, are currently passive actors, although some traditional councils and chiefs are regulating use locally. The Ministry of Small and Medium Enterprises is stimulating small-scale crafts organisations, albeit not specific to bamboo. There appear to be no active actors with technical skills on processing or bamboo agroforestry in Cameroon. Also absent are development or support organisations.

Bamboo across the country is harvested and used directly by $77 \%$ of harvesters as well as being traded. Harvesters are typically middle-aged, married family men, originating from the collection area. They harvest using basic tools, dry the raw material outside or under roof eaves and sell bamboo year-round to local markets, from home or at collection points - with a low level of direct sales to urban markets. Harvest trips, which usually entail head-portering the poles, vary from a few hours to a full day. A small proportion of high volume 'professional' producers collect up to 6000 stems a year, but most harvesters operate at a small-scale and collect around 500 stems a year, earning on average 236208 CFAF but varying from 1625 to more than 2 million CFAF. Mainly exotic bamboo, locally known as Indian or Chinese, 'large green' (Bambusa vulgaris) or 'large yellow' (Bambusa vulgaris vitatta) is collected. Quality is judged by maturity (related to size and colour) and resistance to rot and insects (both while growing and once harvested). Most is sold to processors, for agriculture and to traders, with only $15 \%$ of harvesters processing the bamboo themselves. Bamboo harvest is often a secondary activity, alongside farming, although a quarter of the harvesters interviewed consider bamboo to be their major source of income. Although harvesters' families are often involved in collection, harvesters usually work as individuals; only $13 \%$ belong to a bamboo-related organisation. Access and control differs across regions, with the Northwest and West regions most traditionally regulated. Most bamboo, however, is freely available, and is an 'open access' resource: one-third is either owned or permission is needed for harvest, and in $33 \%$ of these cases, payment is required 
to traditional or village authorities. The majority (57\%) of bamboo harvested is naturally regenerating; only $6 \%$ has been planted and $27 \%$ is a combination of natural generation and planting.

Processors are largely married men, schooled to primary level, on average aged around 36, and who have worked on average for 11 years in the sector. Craftsmen work mainly individually or with apprentices, with one-third being members of enterprises, associations or groups. They tend to source locally, specialise in bamboo crafts and also sell locally and on an informal, small-scale, typically earning a total income of around 150829 CFAF a year. Most use Bambusa vulgaris to construct a range of products, chiefly furniture. These are sold mostly from the roadside or the workshop.

Bamboo traders include middlemen (17\%), wholesalers $(5 \%)$, retailers of unprocessed bamboo $(78 \%)$, and retailers $(92 \%)$ or wholesalers $(8 \%)$ of processed products. Most traders sell unprocessed bamboo poles (56\%); the remainder are processed into furniture and artefacts. A typical trader is a married, middle-aged male with primary schooling, native to the area of commerce with an average household size of five people. Bamboo sales are the major occupation for $32 \%$ of traders interviewed, and all traders have other income sources from trade and agriculture, and $20 \%$ also from crafts. Two-thirds of traders work individually or with family support. One-third are members of an association, mainly specialised in bamboo and rattan crafts. Sales are largely to local clients (77\%), mostly from roadside sales points with on-the-spot, largely negotiated prices. Prices reflect demand, quantity of raw material used and product quality. Average annual revenues from bamboo amount to 709000 CFAF, with a large range from 300 000 to more than 1.2 million CFAF.
Bamboo is consumed across Cameroon and is sold both unprocessed and after going through a series of basic primary and secondary processing activities. The result is at least 14 major product types with more than 43 different actual products. The majority of bamboo is used in construction (50\%), furniture (30\%), agriculture (22\%), tools and utensils (21\%) and fuel $(12 \%)$. It is largely perceived as cheap, in comparison to other materials for equivalent products, but at the same time, produces high quality goods and consumers are open to more and different bamboo-based products.

The policy and regulatory framework around bamboo is largely absent. In the Northwest, West and parts of Adamaoua, local customary rules govern harvest and access. Revisions proposed to the current 1994 Forest Law need to be carefully considered concerning the classification of bamboo (currently neither timber nor a 'special forestry product'); its status, given the smallscale, local trade and high domestic consumption; and, low level of threat given the mainly exotic species used in trade. For Alpine bamboo, sustainable use and forest degradation may be an issue of concern requiring further research. Institutional coordination and concerted support is lacking for the sector.

Problems and constraints include injuries and insect bites, particularly for harvesters. All actors mentioned low demand, storage and product deterioration, lack of knowledge and skills to process and produce better quality and a wider range of products, coupled with the need for improved equipment. This could help address problems of low profits and low prices. Marketing, consumer awareness raising, training, organisation of the market and actors, and sustainable management were also named as opportunities. The growing membership of craftsmen and producer groups is also an encouraging sign of collective action and advocacy within and for the sector. 



\section{Introduction}

Bamboo resources have been known and promoted to enhance the economic and ecological wellbeing of resource dependent communities in Asia. The same effort is recently and gradually being made in Africa, facilitated by the International Network for Bamboo and Rattan (INBAR). INBAR is at the centre of efforts to promote research (on production systems, processing, utilisation and socio-economic impacts), technology transfer (on processing techniques) and exchange of information and capacity building in the bamboo sector globally. This study forms part of INBAR's efforts to develop the bamboo sector in Africa and the Central African subregion in particular, in partnership with the Center for International Forestry Research (CIFOR) and local partners. Given the paucity of information in the bamboo sector in the Central African subregion, a major drive for this research was to provide baseline information that can help guide the development and implementation of relevant development interventions. This in-depth review of the current state and future potential of the bamboo sector in Cameroon has used standard indicators and a common reporting format that permits regional comparisons.

\section{Objectives}

The study's main objective is to conduct and analyse the Production to Consumption System (PCS) of Cameroon's bamboo sector and identify potential development interventions to improve local livelihoods. The specific objectives are:

- To provide detailed information on the types of raw material and products, quantity and quality of bamboo resources, and their production and marketing.

- To examine and report on the sustainability of current management and harvesting practices.

- To examine and report on the primary and secondary processing practices and technologies undertaken.

- To document existing infrastructures, bodies and processes for transportation and commercialisation of bamboo products in Cameroon.

- To provide a typology of stakeholders involved at all levels of the PCS, from farmers to consumers of the final products, and the benefits they derive.

- To review the existing policy environment, rules, regulations and their effectiveness.

- To identify constraints and opportunities for livelihood development of small holders and microenterprises, and develop practical recommendations for improving the bamboo sector.

\section{Rationale for the study}

Forests in Central Africa and Cameroon in particular are facing an annual deforestation rate of about $1 \%$. One of the main drivers is logging for timber and other construction materials. This imposes pressure on forest resources if not properly managed. Pressure on the use of timber products may be reduced by increasing the use of bamboo, rattan and coconut shelves in furnituremaking, a major use of wood raw materials in Cameroon (CRAC/GTZ-MINEF 1999). Planted bamboo can reach maturity in three years and can subsequently be harvested every two years for up to 120 years (Cuddeford 2007). This requires modest investment in planting in order to provide regular revenue. Bamboo fibres are said to be 10 times stronger than wood fibres for construction and bamboo is far lighter and easy to carry than wood (Cuddeford 2007). The social, economic and ecological impacts of the bamboo resource at the local and national level are unknown, however, bamboo has been long regarded as one of the neglected Non-Timber Forest Products (NTFPs) in Central Africa (Tabot-Tabot 2006), despite it being an easily domesticated, renewable resource with annual yields, readily accessible to rural people, and with potential to fuel rural development an aspect long recognised in Asia (Belcher 1998, Marsh and Smith 2006, Ruiz Perez et al. 2009).

The role bamboo could play in sustaining local livelihoods has not been documented, despite its daily usage for producing handicrafts and household items, supporting agriculture, for local transmission posts, and many other uses. Bamboo's widespread usage implies that those who cannot produce themselves buy from those who can supply the resource, leading to a market situation of buying and selling bamboo-related products. This market and the main actors and beneficiaries remain poorly described in Cameroon. Thus, the need for a bamboo PCS study was deemed necessary to define the producers and products, the processors and products processed, the traders and products traded, and the consumers and products consumed - as well as identifying the possible constraints and opportunities in each link in the value chain.

\section{Background to Cameroon}

The Republic of Cameroon is located in Central Africa and covers a total land area of $466326 \mathrm{~km}^{2}$. It is bordered to the east by the Central African Republic $(797 \mathrm{~km})$, northeast by Chad $(1094 \mathrm{~km})$, west and northwest by Nigeria $(1690 \mathrm{~km})$ and south by the 
Republic of Congo $(523 \mathrm{~km})$, Equatorial Guinea (189 $\mathrm{km})$ and Gabon $(298 \mathrm{~km})$. The country lies between latitudes $2^{\circ}$ and $13^{\circ} \mathrm{N}$ (about $1200 \mathrm{~km}$ ) and longitudes $8^{\circ} 30^{\prime}$ and $16^{\circ} 10^{\prime} \mathrm{E}$ (Jonkers and Foahom 2004).

\section{Climate, vegetation and topography}

Cameroon has a tropical climate along the coast, becoming semi-arid, hotter and drier in the north. The country can be divided into four geographic regions on climate and topographic criteria. The southern zone, roughly between $2^{\circ}$ and $6^{\circ} \mathrm{N}$, has a four-season climate, rainfall over $1500 \mathrm{~mm}$ and two dry months. The Congo-Guinean forest zone has closed evergreen or semi-deciduous rainforest, forming an almost unbroken blanket in the south and splitting into islands north of the fourth parallel; it corresponds to the 'humid' and 'low and medium-altitude sub-humid' eco-floristic zones. The coastal zone is a $200 \mathrm{~km}$-wide strip along the sea in which oceanic influences predominate. The single dry season is not very marked, and rainfall decreases from $4000 \mathrm{~mm}$ on the coast up to a maximum 10000 $\mathrm{mm}$ at Debunscha near Mt Cameroon, to 2500 to 3000 $\mathrm{mm}$ some $50 \mathrm{~km}$ inland (Edea) and $2000 \mathrm{~mm}$ along the border of the humid lowland forest zone. It corresponds to the 'low- medium altitude very humid' eco-floristic zone, with an evergreen forest whose vegetation differs from the evergreen forest further inland. The coastal and southern zones make up Letouzey's (1985) 'CongoGuinean' floristic region. The northern zone has a drier Sudano-Sahelian climate with annual rainfall between $500 \mathrm{~mm}$ and $1000 \mathrm{~mm}$. The mountainous Cameroon Highlands zone is found along the volcanic chain from Mt Cameroon though the Northwest to Adamaoua and includes unique Afromontane forests above $2000 \mathrm{~m}$, and rainfall between 1500 to $2600 \mathrm{~mm}$ varying with relief and altitude. The average temperature in the south is $25^{\circ} \mathrm{C}, 21^{\circ} \mathrm{C}$ on mountain ranges and plateau and $32^{\circ} \mathrm{C}$ in the drier north (Jonkers and Foahom 2009). The northern slope of the Adamaoua plateau is a clear boundary within the Soudanian zone.

Cameroon's terrain is diverse, with plains in the north and the southwest, the Adamawa plateau in the centre and high mountains in the west. The highest point is Mt Cameroon ( $4095 \mathrm{~m}$ ) in the Southwest region and the lowest is sea level. For most part the country lies between 200 and $800 \mathrm{~m}$ above sea level. Lake Chad is in the far north and straddles the border with Chad. Three major rivers flow into the Atlantic: the Wouri, the Nyong and the Sanaga, which is formed from the confluence of the Lom (which flows from the northwest) and the Noun (which flows from the east). The Dja arises in the east and flows out of the country into Congo in the east. The Bénoué River flows north to Nigeria through Lagdo reservoir. Cameroon has bauxite, iron ore and petroleum resources.

\section{Demography}

Cameroon's population was estimated at 19.4 million as of 1 January 2010, a projection derived from the Population and Housing Census of November 2005. This is based on an estimated annual growth rate of $2.6 \%$. A little over half $(50.5 \%)$ of the population is female, and $43.6 \%$ of the population is less than 15 years old (Government of Cameroon 2010). The urban population is increasing with $52 \%$ now living in urban areas, up from $48.9 \%$ in 2000 . The average population density is 35.2 inhabitants per $\mathrm{km}^{2}$ (FAO 2007), but varies considerably per region, from less than five people per $\mathrm{km}^{2}$ in some savannah and moist forest regions, rising to $90-100$ people per $\mathrm{km}^{2}$ in parts of the west. Three-quarters of the male population and $52 \%$ of the female population over 15 years old are literate. The male/female ratio for the population is 1.01. The main ethnic groups are the Cameroon highlanders (31\%) and the Equatorial Bantu (19\%), Kirdi (11\%) Fulani (10\%), the Northwestern Bantu (8\%) and the Eastern Nigritic (7\%) (Neba 1999, CIA 2009). There are more than 250 linguistic groups with strong cultural identities associated with the ecological zones where they live. The Bantus are the dominant farming populations in the humid forest zone while marginalised indigenous groups include the pygmies (Aka, Baka, Bakola and others) (Topa et al. 2009). About $25 \%$ of the population adheres to traditional religion (indigenous beliefs); about 22\% is Muslim; the remaining majority is Christian (Jonkers and Foahom 2009). The official languages are English and French, with the latter dominating while the former is confined to the former British colony in the Northwest and Southwest regions.

\section{Governance}

Cameroon is a republic with a constitution and a legal system based on French civil law. Politically Cameroon divided into 10 administrative regions. Throughout Cameroon, political parties and associations have been superimposed on traditional structures. In the last two decades administrative functions have been decentralised, devolving power but not always corresponding financial budgets to local councils and communities (Topa et al. 2009).

\section{Socio-economics}

The GDP per capita is US\$651 and real growth rate is $4.8 \%$ (FAO 2007), however $40 \%$ of the population lives under the poverty line. Agriculture accounts for $44 \%$ of GDP, industry for $16 \%$ and service industries for the remaining $40 \%$ (CIA 2009). Seventy per cent of the working population is employed in the agricultural sector. Cameroon is classified as a mediumincome country, with a Human Development Index of 0.532 in 2008 (UNDP 2009) but many development 
Table 1. Cameroon Human Development Indices

\begin{tabular}{lr}
\hline Indicator & Cameroon \\
\hline Literacy rate & $67.9 \%$ \\
Life expectancy at birth & 50.8 \\
Gross Domestic Product (GDP) per capita 2005 (purchasing power parity US\$) & 2.299 \\
Human Development Index 1995-2005 & Increase \\
Population living below: & $17.1 \%$ \\
$\quad$ - US\$1/day & $50.6 \%$ \\
- US\$2/day & $40.2 \%$ \\
$\quad$ - National poverty line & 6.3 \\
Births per woman & $33 \%$ \\
Population undernourished 1990/92 & $26 \%$ \\
Population undernourished 2002/04 & $5.4 \%$ \\
HIV prevalence (15-49 age group) 2009 & 138 \\
Cell phone subscribers (per 1000 people) & 25.4 \\
Net Official Development Assistance per capita (US\$) & $4.0 \%$ \\
Net Official Development Assistance as \% GDP 1990 & $2.5 \%$ \\
Net Official Development Assistance as \% GDP 2005 & 2.4 \\
TI corruption perception index & 144 \\
\hline Overall HDI rank (out of 177 countries) & \\
\hline
\end{tabular}

Sources: United Nations 2007, 2009, United Nations 2008, World Bank 2009, Transparency International 2008

challenges remain (see Table 1). Because of its relative political stability, timber and oil resources and favourable agricultural conditions, Cameroon has one of the bestendowed, functioning primary commodity economies in sub-Saharan Africa.

\section{Infrastructure}

Cameroon has $34300 \mathrm{~km}$ of roads of which $4288 \mathrm{~km}$ are paved. Plans to upgrade and connect Cameroon to the African international highway system are ongoing, with routes to Equatorial Guinea and Gabon in the south, and Central African Republic to the east completed, but not to Nigeria in the west. There is $1104 \mathrm{~km}$ of onemetre gauge railway with the main line leading from Douala on the coast through the capital Yaoundé and up to Ngaoundéré in the nation's centre. There are 11 airports with paved runways but only three (Douala, Yaoundé and Maroua) served with regular flights, and 39 with unpaved runways. There are about $2090 \mathrm{~km}$ of waterways, with the main ports of Douala, Limbe and Kribi on the Atlantic coast and Garoua on the river in the north, which handles exports to Nigeria. Cameroon is dependent on hydropower for $97.5 \%$ of its power. The fixed telephone system that was previously largely only available to business and government has been transformed in the last five years by mobile networks that cover the majority of towns and cities.

\section{Cameroon's forestry sector}

More than $47 \%$ of Cameroon's national territory is forested (de Wasseige et al. 2009). The forest is mainly closed tropical broad-leaved rainforest with three predominant types: lowland evergreen, lowland semi-deciduous, and montane. The closed forests are concentrated in the south and along the coast. Cameroon's dense forested zone covers 19.6 million ha, about $40 \%$ of the national territory, and is described as some of the most biologically diverse and most threatened forests (Topa et al. 2009, CBFP 2006, GFW 2005). Areas of mangroves are found in the Gulf of Guinea and Acacia savannah woodland occurs in the north. Cameroon has a modest area of plantation forest (Jonkers and Foahom 2009). While low by international standards, Cameroon has one of the highest Central African annual deforestation rates $(0.14 \%$ in the humid zone), and an annual net degradation rate of $0.01 \%$ (de Wasseige 2009). However, when including the savannah zone, it is below the African average of $1 \%$. The Government of Cameroon adopted a new forestry law in 1994, highlighting its strategies for making the forestry sector contribute to the nation's socio-economic development by involving local communities, NGOs, and economic operators, as well as international communities. The forest zoning plan in Cameroon now covers 14 million ha, with growing recognition of the customary rights and socio-economic welfare contributions of forests at local and national levels. The forest sector is Cameroon's largest employer outside the public sector, providing 13000 formal and 150000 informal jobs, and is the second largest source of export revenue after petroleum (29\% and 26\% of nonpetroleum exports in 2001 and 2004 respectively) (Topa et al. 2009). The total value of 
Table 2. Cameroon forest key figures

\begin{tabular}{lrc}
\hline Aspect & Figures & Date \\
\hline Forest cover as \% of total surface area & $59 \%$ & 2009 \\
Public forest ownership & $86 \%$ & 2005 \\
Industrial round wood production & 2.3 million m & 2006 \\
Formal forestry sector employment & $12-13000$ & 2006 \\
Contribution forestry sector to GDP & $6 \%$ & 2004 \\
Value of forest products exports & $\$ 488$ million & 2006 \\
\hline
\end{tabular}

Sources: de Wasseige et al. 2009, Fometé and Cerutti 2008, World Bank 2009

forest products in Cameroon for which some statistics exist - timber, charcoal, Gnetum spp., gum arabic and Prunus africana bark - is about US $\$ 870$ million, of which US\$120 million is from NTFPs (Ingram 2009). In 1994, Cameroon introduced a number of forest policy reforms, both regulatory and market-based, to support a more organised, transparent and sustainable system for accessing and using forest resources (Topa et al. 2009). Policy and development focused attention has increasingly been directed towards the value chains of NTFPs in the last decade.

In Cameroon, the State defines forestry sector policies, forest management regulations and grants logging rights. Cameroon's forests are governed by the 1994 Forestry Law and its 1995 Decree of Application. Another important legal regulation on forestry and wildlife was the implementation of the National Zoning Plan and guidelines. The National Zoning Plan is an indicative framework for land use in the southern forested area. It acts as a tool for the planning, orientation and exploitation of natural resources within the area (Jonkers and Foahom 2004). Cameroon's forest is divided into permanent and non-permanent forest domains as defined in Cameroon's 1994 Forest Law. The permanent domain consists of protected areas, Council Forests and Forest Management Units (FMUs) - concessions designated for sustainable timber production. Non-permanent forests are forests that used for uses other than timber exploitation, and include other forests, community forests and privately owned forests. In non-permanent forest areas, the legal framework for usage rights permits a non-exhaustive list of traditional activities, which includes felling trees for fuel wood or construction, lopping, chopping protected species, gathering dead wood, collecting 'secondary' forest products (raffia, rattan, palm products, bamboo, food products, etc), gathering, hunting, fishing, grazing, farming, etc. (Nguiffo, Kenfack, and Mballa 2009)

\section{Non-timber forest products}

The forests of Central Africa and Cameroon are rich in non-timber forest products (NTFPs), which have long been an important component in the livelihood strategies of forest-dwelling people, providing subsistence needs, employment and cash income (Arnold and Ruiz-Pérez 1998). A number of 'guesstimates' (Calibre Consultants and SSC University of Reading 2000) propose that between one-in-four to one-in-six of the world's poor depend directly or indirectly on forests for their livelihoods (World Bank 2002, FAO 2008). Timber and other forests products provide 350 million people living in or around tropical forests with $50 \%$ or more of their household needs and also directly provide $10 \%$ of jobs in developing countries (Ames 1998). In a region where forests cover $44.6 \%$ of the land area (FAO 2007), about $62 \%$ of the rural population depends on access to forests to meet their daily needs for subsistence, employment and cash income (Tieguhong et al. 2009, Tieguhong and Ndoye 2004 and 2006, Arnold and Ruiz-Perez 1998). Most Cameroonians, particularly the rural inhabitants, depend on NTFPs for subsistence and cash income. At the household level, forests directly provide about 8 million rural and poor Cameroonians with traditional medicines, food, domestic energy and construction materials (Topa et al. 2009). For example, the value of the NTFP forest sector from just five NTFPs chains from the heart of the Congo Basin in Cameroon and Democratic Republic of Congo (Honey, Gnetum spp., Irvingia spp., Dacryodes edulis and Prunus Africana) were found to have a combined annual value of at least US $\$ 45$ million, providing employment to 270000 people from forests to urban areas (Ingram 2009).

There has been increased interest in the collection and marketing of NTFPs as an instrument for sustainable rural development (Tieguhong and Ndoye 2004). One approach has been to work with rural communities and participants involved in the NTFP value chains (Tieguhong et al. 2009). In Cameroon, the main NTFPs extracted by forest-dwelling people are fuelwood; poles used for house construction; wild fruits such as Irvingia spp. and Ricinodendron heudelotii, both used as condiments; medicinal plants such as Prunus Africana, used for treating prostate enlargement; fruits and leaves for food, such as Dacryodes edulis, Gnetum africanum, and stimulant nuts Garcinia kola, Cola acuminate; rattans and Rhaphia spp. palms for construction (Sunderland et al. 2002); and, numerous animal species, collectively known as bushmeat (Tieguhong et al. 2009, Ingram 2009, Ndoye and 
Tieguhong 2004). However, the development of key NTFPs to constitute sustainable income generating forest-based enterprises has been hampered by inadequate political, economic, technical and legal arrangements. This is aggravated by the lack of statistics on the contribution of the various NTFPs to local, national and regional economies (Clark and Sunderland 2004, Tieguhong and Ndoye 2006). Many of the species recognised for their economic contributions to livelihoods and large scale trade are not sufficiently domesticated to ensure that supply is greater than market demand. This has led some wild species being classified as vulnerable and their international trade restricted to reduce the ecological pressures on wild populations. Examples are Prunus africana and Pericopsis elata. This is also relevant for bamboo and its products in both Cameroon and Central Africa, which according to Tabot-Tabot (2006) are a forgotten resource.

\section{Review of bamboo sector in Cameroon}

A literature review reveals remarkably little on bamboo in Cameroon. Dedicated journals such as the International Journal of Bamboo and Rattan and the Bamboo Journal have no data at all for Cameroon. The main botanic and ecology experts at the universities of Dschang and Buea, and the National Herbarium and Royal Botanic Gardens of Kew, do not know of any taxonomic or ecological study on bamboo in Cameroon, only for grasses in general (van der Zon 1992).

Therefore an extensive literature review was conducted, ranging across forestry, ecology, botany, socio-economics, culture and anthropology, to provide as much background data as possible to guide the second stage of the study - the stakeholder interviews and selection of sites for field work.

\section{Bamboo species in Cameroon}

A misunderstanding arises in Anglophone Cameroon due to 'bamboo' or 'raffia bamboo' being the common name for raffia poles and materials originating from Raphia palms, as shown in Figure 1. In pidgin 'Indian bamboo' is also used to denote Raphia and 'Chinese bamboo' is the term often used for bamboos of the Graminae family. This is even the case in areas such as Oku in the Northwest, where extensive stands of native bamboo are found. This classification can create widespread confusion during field work and even in the scientific literature (Gautier 1992) as to which plant species is actually being referred to. The species descriptions in Table 3 and Figures 1, 3, 4 and 5 serve as a field guide.

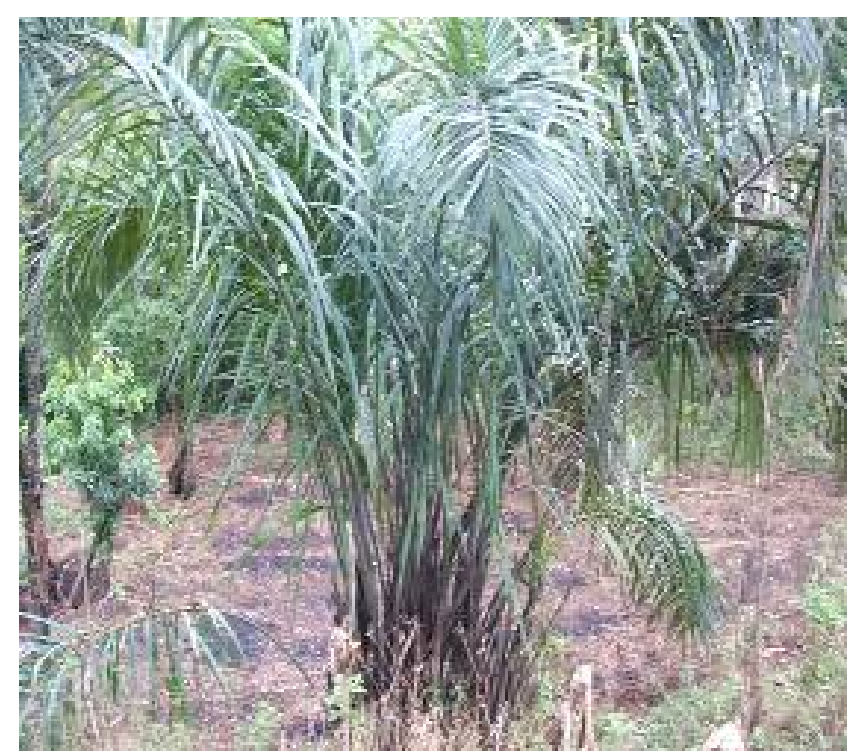

Figure 1. Raphia mambilenses or Indian bamboo

Compared to the Americas - which are collectively much richer in bamboo species than either continental Africa or Madagascar but have a lower diversity than the Asia-Pacific region, with approximately 430 species of New World woody bamboos - Africa is strikingly poorer in bamboo species, with the highest species richness found in northern Madagascar. Only Arundinaria occurs in both the Old and New Worlds. The highest potential species number recorded in South America was $35 / \mathrm{km}^{2}$, while the corresponding figure for Asia is $144 / \mathrm{per} \mathrm{km}^{2}$. Africa has only three known native bamboo species, two of which can be found in Cameroon (Table 3).

Bamboo species belong to the Graminae (grass) family. Grasses are one of the most important plant families of Cameroon with a very rich flora represented by 433 species, in 125 genera and 19 tribes. The dry savannas of the North region and the mountainous areas of central and western Cameroon contain extensive grass areas which are important for cattle and fauna in general. The montane highlands and Adamou uplands possess the richest grass species diversity, as open vegetation in Cameroon is often dominated by grasses. Specimens from these areas are well represented in plant collections, particularly in the National Herbarium Yaoundé, Limbe Botanic Garden, Royal Botanic Garden Kew, Natural History Museum Paris, University of Wales Bangor. Garoua Wildlife School for the vegetation of northern Cameroon, the Highlands area in the Bambui research station, and in Limbe Botanic Garden for grasses from Mt Cameroon. Grasses from the rainforest zone are poorly represented in collections because of the low importance many forest botanists attach to grasses; they generally look upwards instead of downwards and think of grasses as secondary species. 


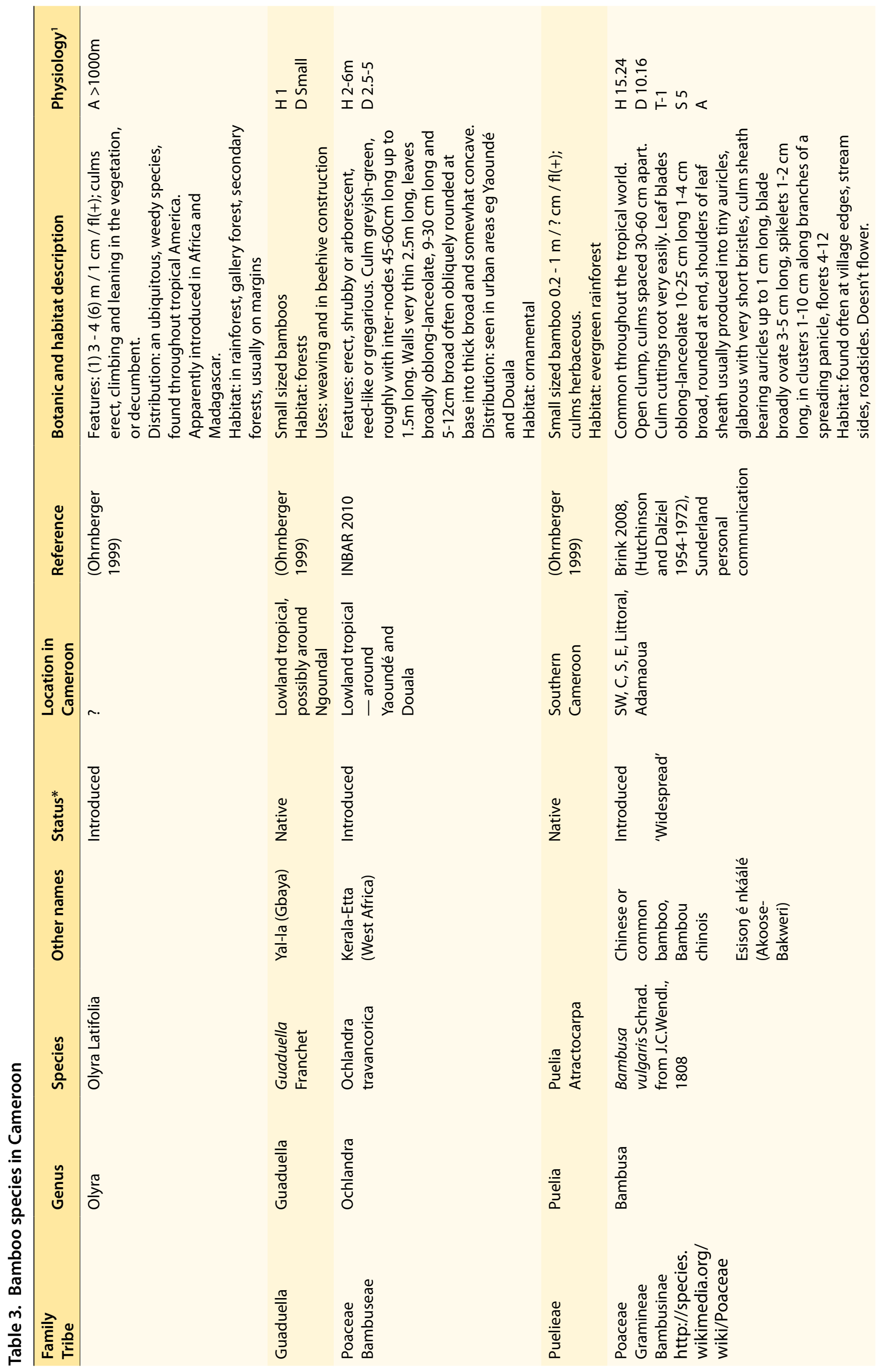




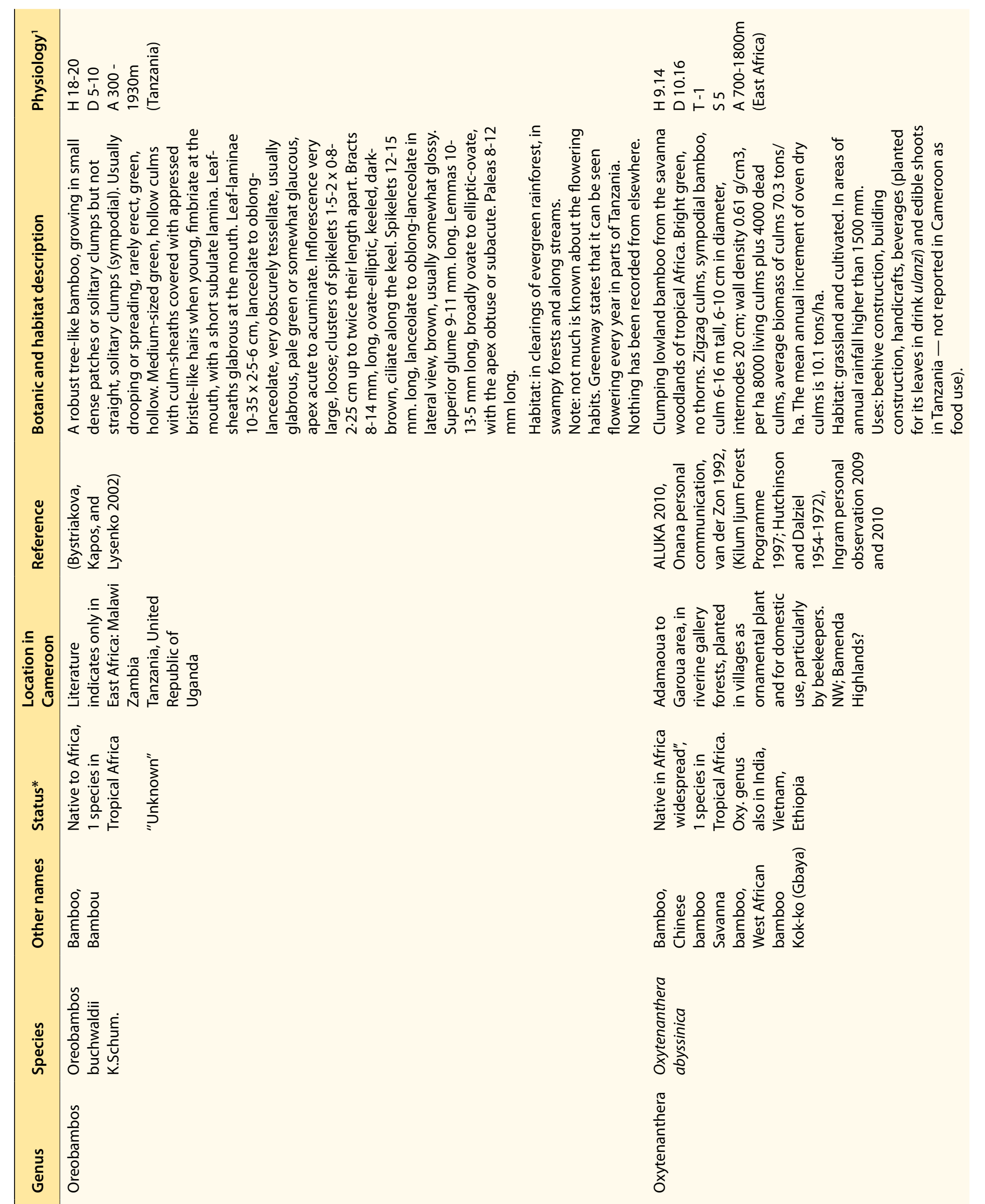




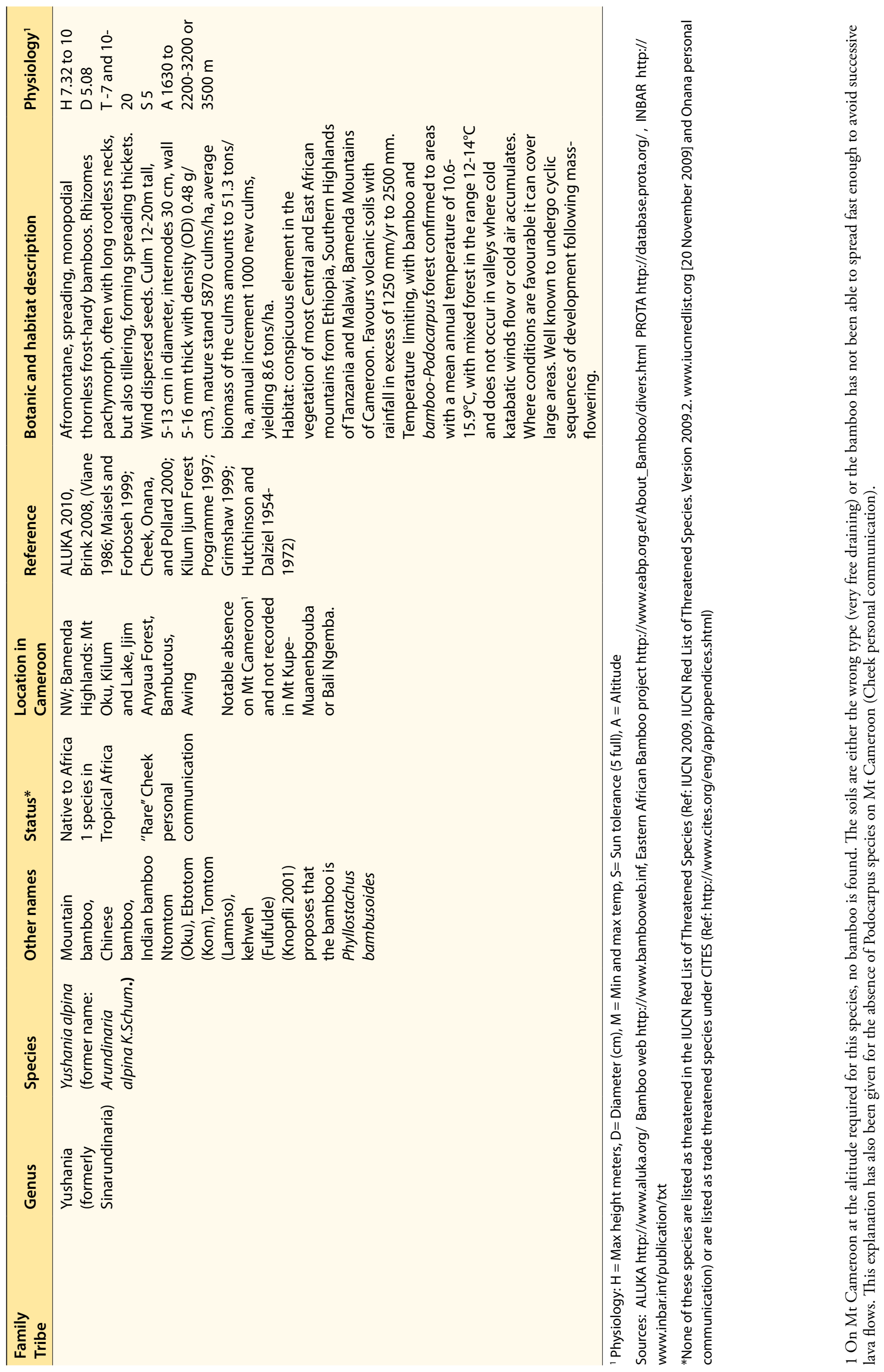


The tribe Paniceae, with several grain-providing species, occurs everywhere but is less dominating with a number of smaller bamboo-like groups that are shade-tolerant and occur in the rain forest. The southern limit of the vegetation zones, so obvious in the western Sahel, is hardly found in Cameroon where a more gradual vegetal transition is found along the Adamaoua plateau. Andropogon gayanus is a very clear indicator species here. Although the Extreme North region of Cameroon has recently suffered seriously from drought and the vegetation is degraded compared with a few decennia ago, no clear modification of the location of the vegetation zones is visible. Grasses are generally well adapted to fire, with seedling recruitment and regeneration seemingly little affected by wild fire. Frequent burning, as is commonly practised for agricultural land clearance and to provide new grazing pastures, causes grasses to dominate. When fires are prevented, vegetation tends to be dominated by woody species (van der Zon 1992).

No data about phenology and in particular flowering in Cameroon has been found. This is important given the characteristic of some bamboo species, where one massive flowering event causes all individuals to die. This can happen about once in every 100 years and has yet to occur in most of West and Central Africa. When it does, it could be catastrophic for the resource and livelihoods associated with it. In this respect, knowledge of which species is used where could be critical. Much of the bamboo used is non-indigenous Bambusa vulgaris and possibly other introduced species (Personal communications Sunderland, Cheek, Onana). However, in the Northwest, the montane species (formerly known as Arundinaria alpina and now Yushina alpina) is predominant, although Bambusa vulgaris has also been planted in the area. Oxytenanthera abyssinica is thought to be much less widely spread and used, but where it occurs in remote areas of Adamaoua, it is critical to livelihoods.

\section{Resource quantities}

Very little data on resource quantities exists in the literature. Although the mountain zone of bamboo in Kilum Ijum is documented (Cheek, Onana, and Pollard 2000; Maisels and Forboseh 1999), the surface area and biomass is not given. Based on maps and recent forest inventories (Foaham et al. 2009), approximately 2000 to 4000 ha of bamboo is estimated, out of the total area of forest of $200 \mathrm{~km}^{2}$ (Figure 2 and Figure 19). In the Northwest in general, Figure 20 provides a guide, although land use changes over the last 45 years have seen the bamboo in Awing and the Bamboutous Mountains diminish substantially. From these two maps an estimated 4000-5000 ha of bamboo is estimated to still exist in the Northwest. Data on bamboo resource availability in other parts of Cameroon is unavailable and was not part of the Terms of Reference for this study, presenting a major gap in knowledge and highlighting the need for at least a resource inventory of the major production zones, or a national inventory.

\section{Sustainability of current management and harvesting practices}

In Cameroon there are no guidelines or standards for sustainable harvesting of bamboo. A review of the literature revealed only one source on the sustainability and harvesting of African bamboo generally. In Uganda, where the shoots of the mountain bamboo (formerly Arundinaria alpina and now referred to as Yushina alpina) are eaten, it has been difficult to assess whether or not harvesting is at a sustainable level (ETFRN 2003). Threats to mountain species in heavily populated areas - typical for Alpine bamboo - are well known. Pressure occurs from firewood collection (for heating and cooking) which is a major contributor to forest degradation. Fires of human origin are common along forest edges in submontane areas and can cause substantial changes in forest structure. Hunting is also common and has a direct impact on faunal populations and an indirect impact on forest cover, as hunters regularly burn the vegetation at forest edges (and sometimes the forest itself) to ease access and to concentrate grazing animals in areas of young vegetation. Significant areas of montane cloud forests have also been converted to agriculture and plantations, especially in submontane areas in Africa, where agriculture is found as high as $2400 \mathrm{~m}$ in altitude and pastures as high as 2000-3000 m (Letouzey 1985, Doumenge et al. 1993), as is the case around $\mathrm{Mt}$ Oku. As both the forest type and threats are exactly the same in the Bamenda Highlands where Yushina alpina is also found (Parrott and Parrott. 1989; Abott et al. 2001; Whinconet 2005; Ingram and Jam 2008), it is anticipated that similar threats for this species are present in Cameroon, given its 'rare' status in the mountains of the northwest Cameroon highlands (Cheek, Onana, and Pollard 2000). An important factor will be the level of management. As the species is not regulated officially (see section on regulatory and customary rules), the customary rules governing harvest and actual practices are critical. Reports on forest management in the Kilum Ijum forest (Cunningham $e t$ al. 2002) indicate there has been, and still is, some level of control on harvesting. For the non-native Bambusa vulgaris no data was found on customary management.

Edouard et al. in Belcher (1998) note that intensively managed NTFP production systems may completely displace the natural vegetation within the management unit, as is frequently the case for bamboo. However, the impacts at the landscape or local level are less clear for some of the less intensively managed cases. In most cases, the ecological and biodiversity impacts have not been measured or even estimated and assessing impacts needs a clear baseline. Belcher (1998) also questions if 


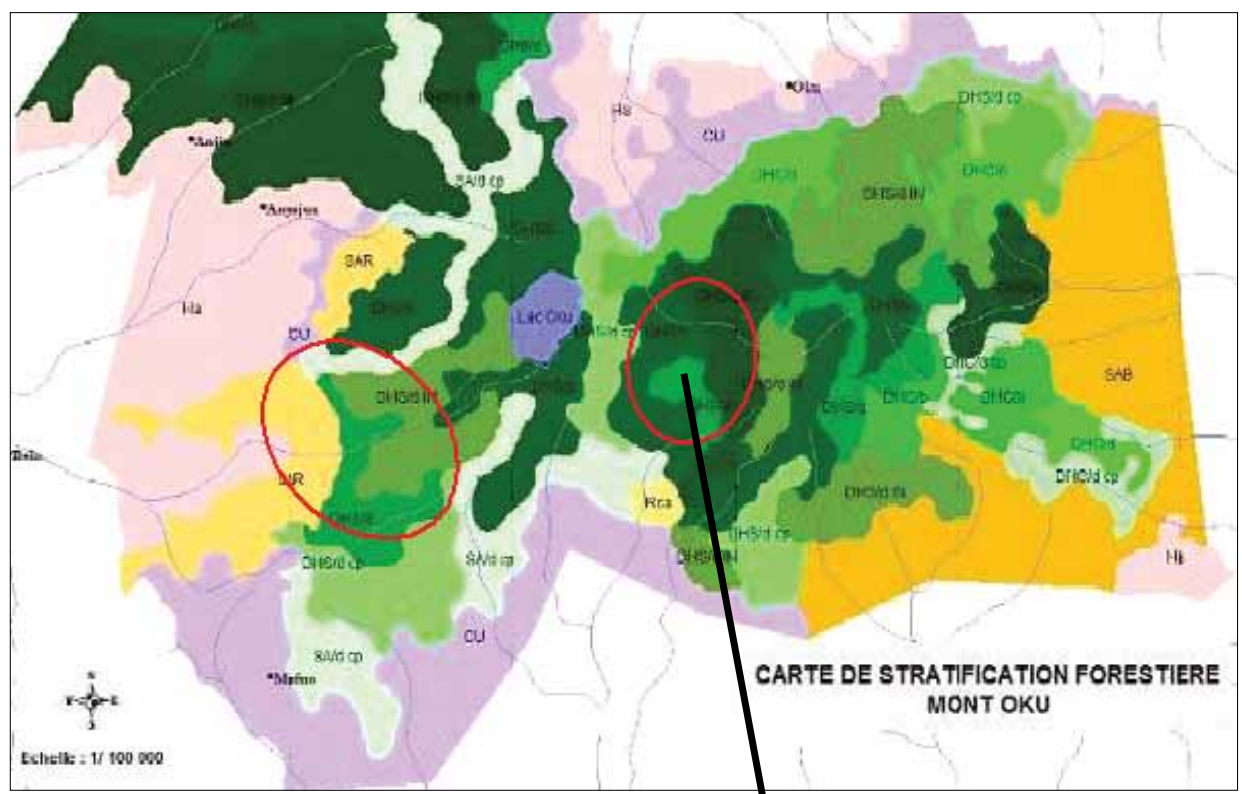

Figure 2. Stratification of Kilum ljum forest, NW Cameroon

Map source: Foaham et al. 2009

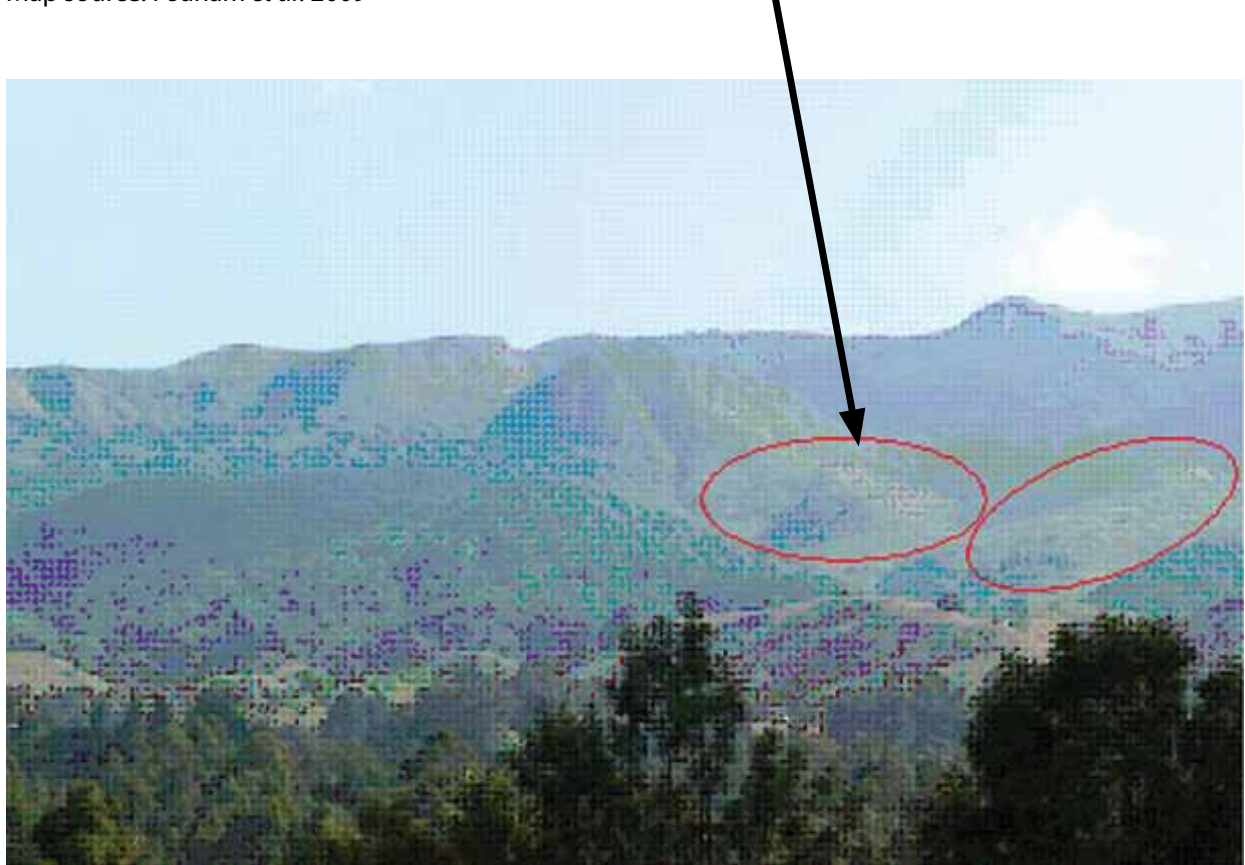

Figure 3. Yushina alpina groves in Kilum ljum forest, Northwest 

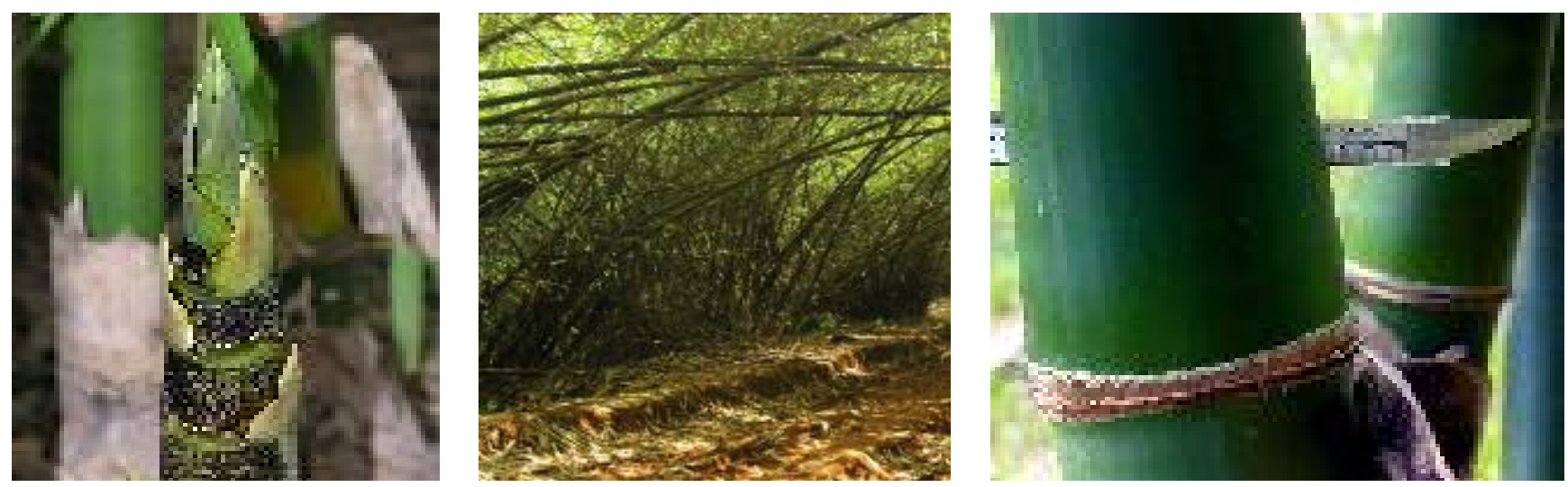

Figure 4. Bambusa vulgaris
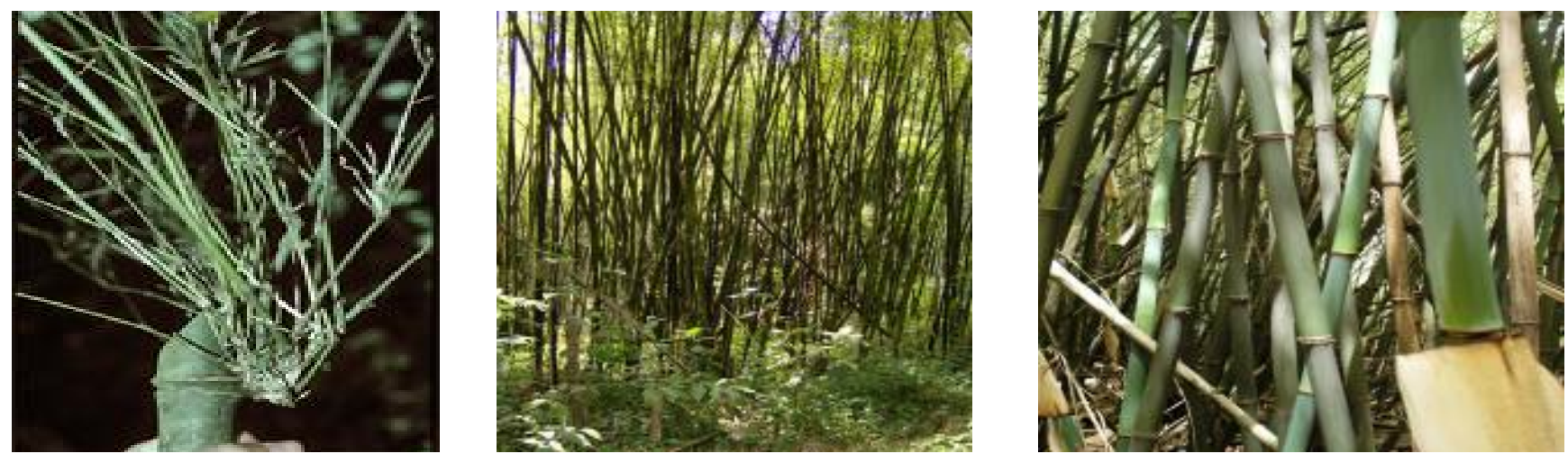

Figure 5. Yushania alpina
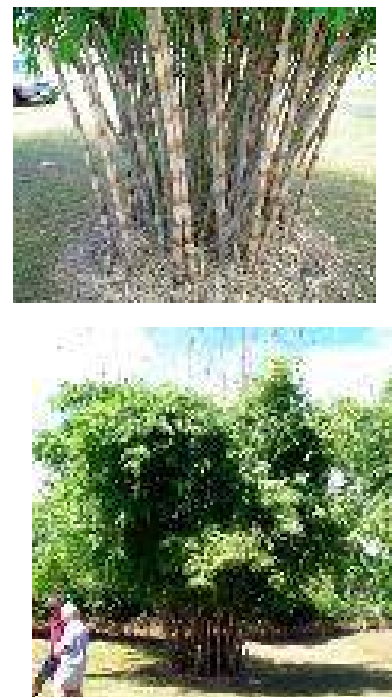
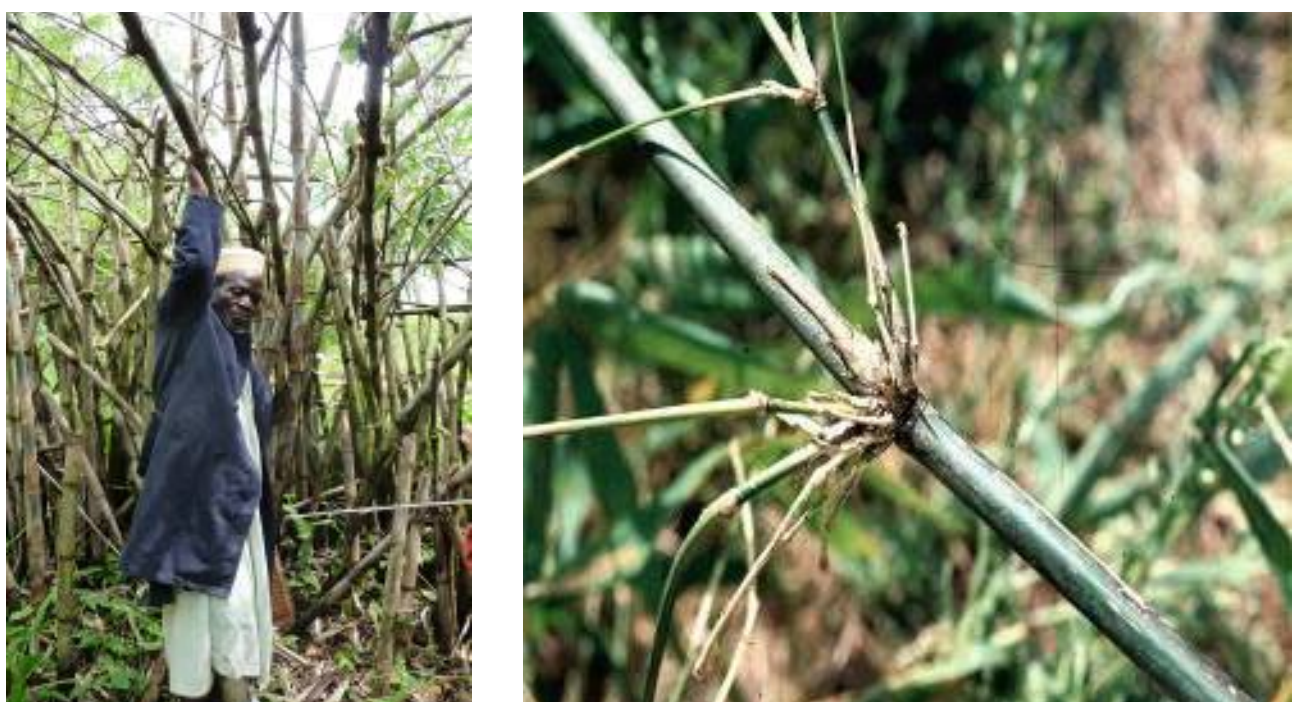

Figure 6. Oxytenanthera abyssinica 

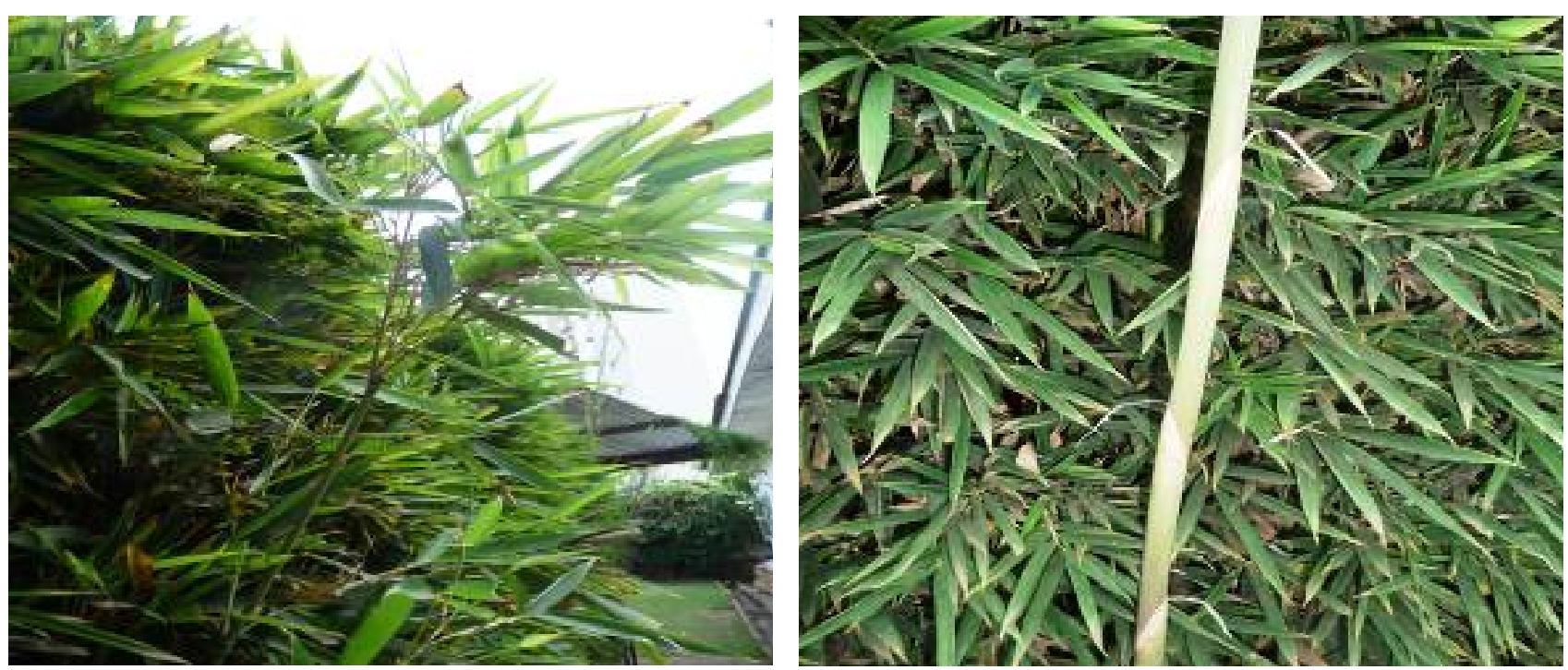

Figure 7. Ochlandra travancorica

Ochlandra travancorica Small diameter, 'green' bamboo

Mainly used ornamentally and for fencing, also for some crafts

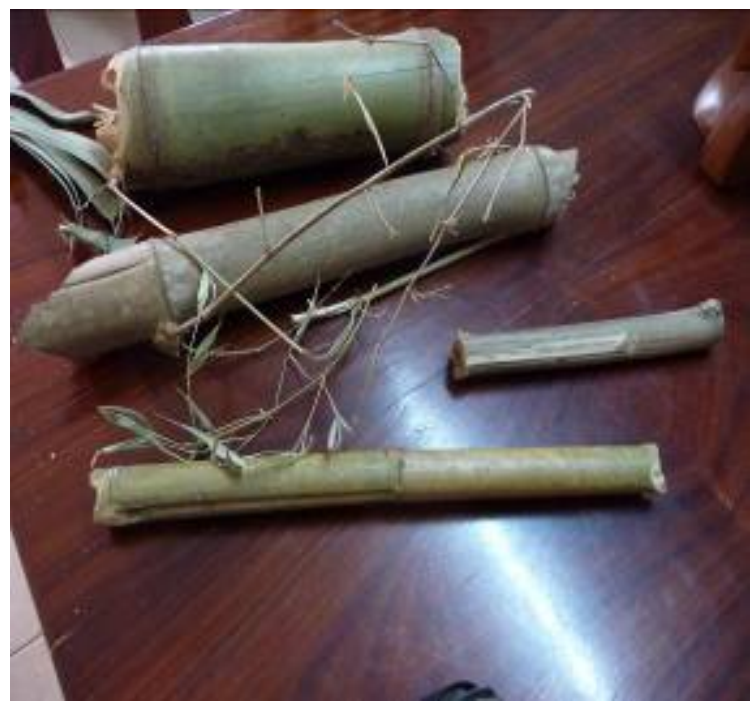

Top to bottom: Large green

(Bambusa vulgaris), Yellow (Bambusa

vulgaris vitatta), Small green

(Ochlandra travancorica), Small

yellow (unidentified)

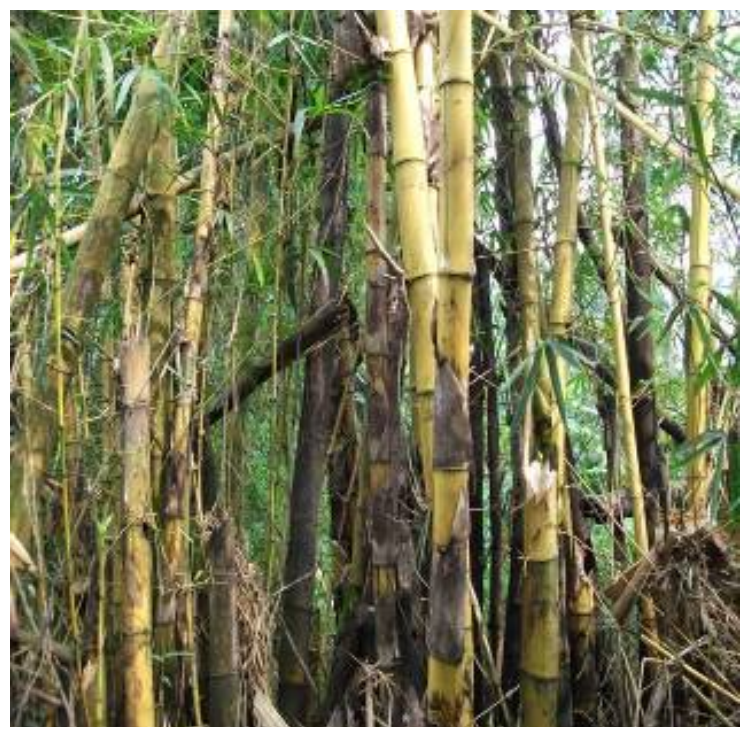

Figure 8. Bambusa vulgaris vitatta

Yellow bamboo

Bambusa vulgaris vitatta 


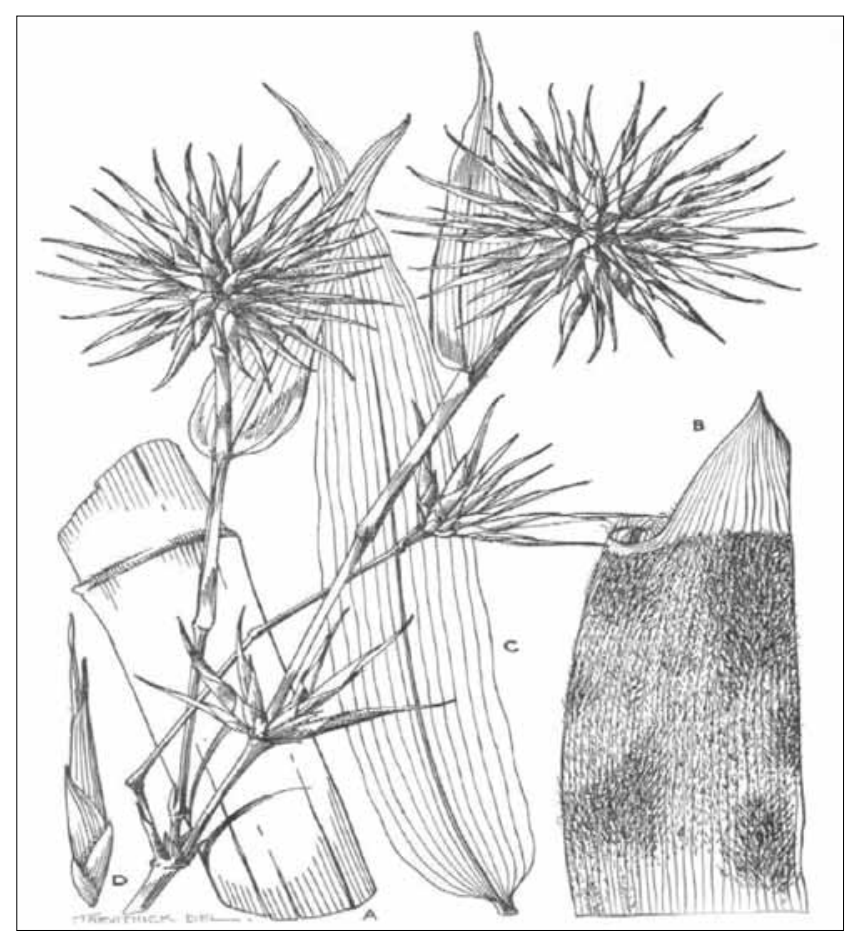

Figure 9. Oxytenanthera abyssinica

Source: Hutchinson and Dalziel 1954-1972

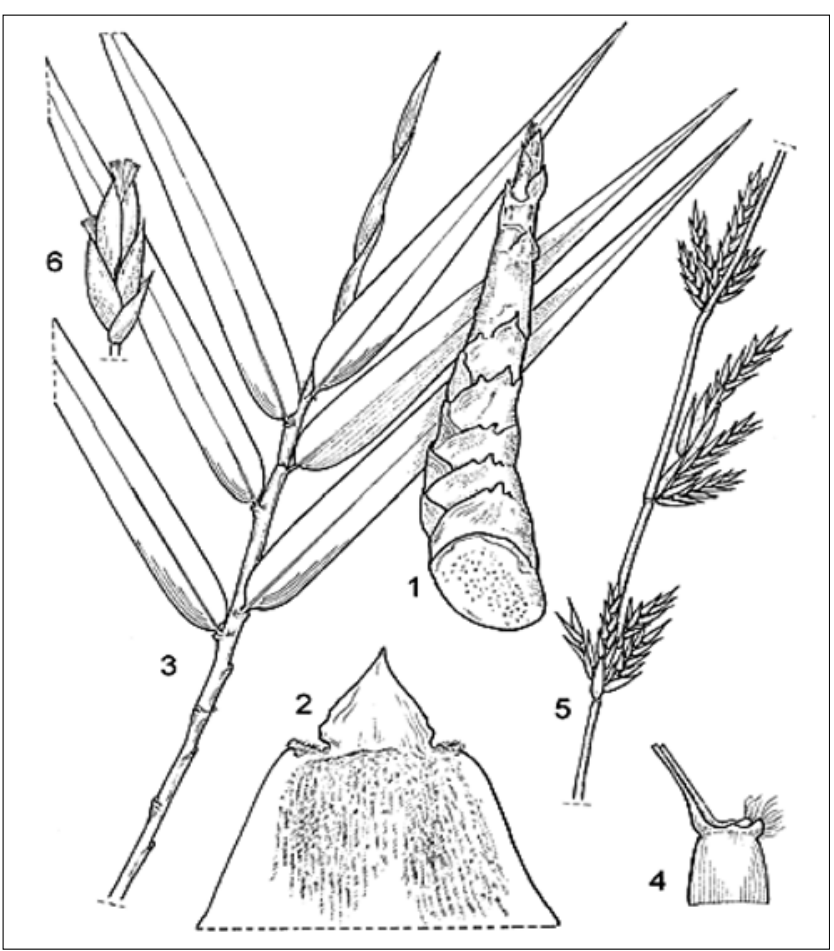

Figure 11. Bambusa vulgaris

Bambusa vulgaris: 1 . young shoot; 2 . stem leaf; 3. leafy branch; 4 . upper part of leaf sheath; 5. flowering branchlet; 6 . spikelet. Source: Brink 2008

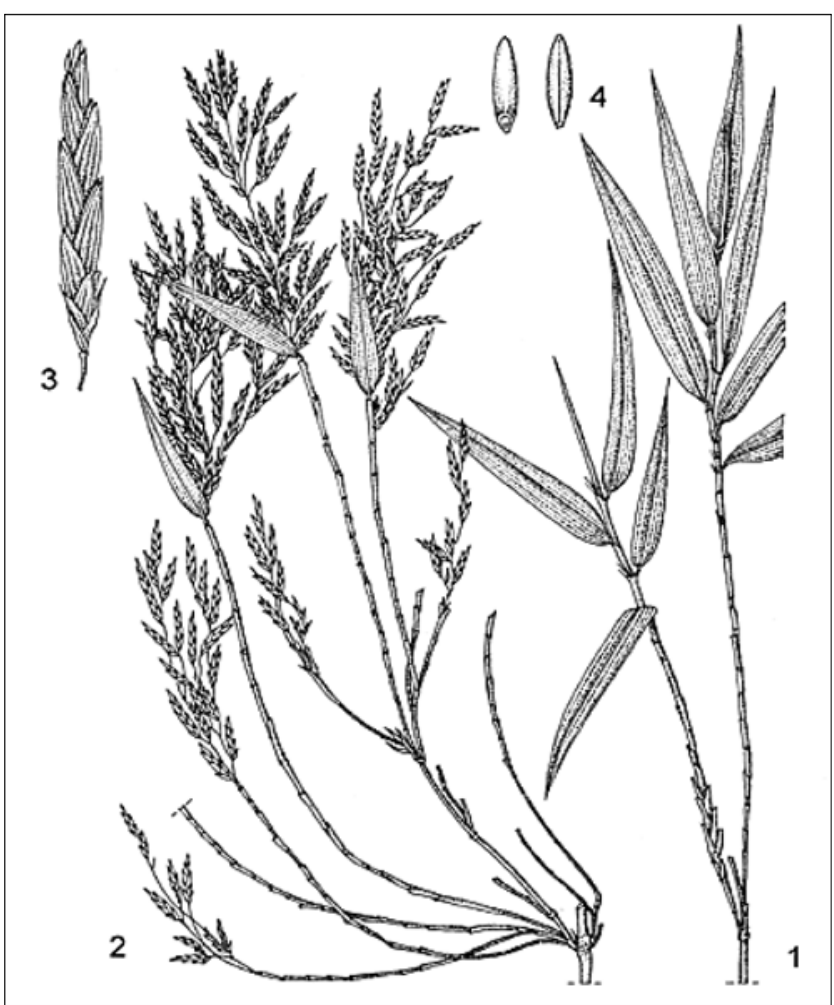

Figure 10. Yushania alpina

Yushania alpina: 1 . leafy branches; 2 . flowering branches; 3 . spikelet; 4 . grains.

Source: Hall and Inada 2008

The tribe Paniceae, with several grain-providing species, occurs everywhere but is less dominating with a number of smaller bamboo-like groups that are shade-tolerant and occur in the rain forest. The southern limit of the vegetation zones, so obvious in the western Sahel, is hardly found in Cameroon where a more gradual vegetal transition is found along the Adamaoua plateau. Andropogon gayanus is a very clear indicator species here. Although the Extreme North region of Cameroon has recently suffered seriously from drought and the vegetation is degraded compared with a few decennia ago, no clear modification of the location of the vegetation zones is visible. Grasses are generally well adapted to fire, with seedling recruitment and regeneration seemingly little affected by wild fire. Frequent burning, as is commonly practised for agricultural land clearance and to provide new grazing pastures, causes grasses to dominate. When fires are prevented, vegetation tends to be dominated by woody species (van der Zon 1992).

No data about phenology and in particular flowering in Cameroon has been found. This is important given the characteristic of some bamboo species, where one massive flowering event causes all individuals to die. This can happen about once in every 100 years and has yet to occur in most of West and Central Africa. 
When it does, it could be catastrophic for the resource and livelihoods associated with it. In this respect, knowledge of which species is used where could be critical. Much of the bamboo used is non-indigenous Bambusa vulgaris and possibly other introduced species (Personal communications Sunderland, Cheek, Onana). However, in the Northwest, the montane species (formerly known as Arundinaria alpina and now Yushina alpina) is predominant, although Bambusa vulgaris has also been planted in the area. Oxytenanthera abyssinica is thought to be much less widely spread and used, but where it occurs in remote areas of Adamaoua, it is critical to livelihoods.

\section{Resource quantities}

Very little data on resource quantities exists in the literature. Although the mountain zone of bamboo in Kilum Ijum is documented (Cheek, Onana, and Pollard 2000; Maisels and Forboseh 1999), the surface area and biomass is not given. Based on maps and recent forest inventories (Foaham et al. 2009), approximately 2000 to 4000 ha of bamboo is estimated, out of the total area of forest of $200 \mathrm{~km}^{2}$ Figure 2 and Figure 18). In the Northwest in general, Figure 20 provides a guide, although land use changes over the last 45 years have seen the bamboo in Awing and the Bamboutous Mountains diminish substantially. From these two maps an estimated 4000-5000 ha of bamboo is estimated to still exist in the Northwest. Data on bamboo resource availability in other parts of Cameroon is unavailable and was not part of the Terms of Reference for this study, presenting a major gap in knowledge and highlighting the need for at least a resource inventory of the major production zones, or a national inventory.

\section{Sustainability of current management and harvesting practices}

In Cameroon there are no guidelines or standards for sustainable harvesting of bamboo. A review of the literature revealed only one source on the sustainability and harvesting of African bamboo generally. In Uganda, where the shoots of the mountain bamboo (formerly Arundinaria alpina and now referred to as Yushina alpina) are eaten, it has been difficult to assess whether or not harvesting is at a sustainable level (ETFRN 2003). Threats to mountain species in heavily populated areas - typical for Alpine bamboo - are well known. Pressure occurs from firewood collection (for heating and cooking) which is a major contributor to forest degradation. Fires of human origin are common along forest edges in submontane areas and can cause substantial changes in forest structure. Hunting is also common and has a direct impact on faunal populations and an indirect impact on forest cover, as hunters regularly burn the vegetation at forest edges (and sometimes the forest itself) to ease access and to concentrate grazing animals in areas of young vegetation. Significant areas of montane cloud forests have also been converted to agriculture and plantations, especially in submontane areas in Africa, where agriculture is found as high as $2400 \mathrm{~m}$ in altitude and pastures as high as 2000-3000 m (Letouzey 1985, Doumenge et al. 1993), as is the case around Mt Oku. As both the forest type and threats are exactly the same in the Bamenda Highlands where Yushina alpina is also found (Parrott and Parrott. 1989; Abott et al. 2001; Whinconet 2005; Ingram and Jam 2008), it is anticipated that similar threats for this species are present in Cameroon, given its 'rare' status in the mountains of the northwest Cameroon highlands (Cheek, Onana, and Pollard 2000). An important factor will be the level of management. As the species is not regulated officially (see section on regulatory and customary rules), the customary rules governing harvest and actual practices are critical. Reports on forest management in the Kilum Ijum forest (Cunningham $e t$ al. 2002) indicate there has been, and still is, some level of control on harvesting. For the non-native Bambusa vulgaris no data was found on customary management.

Edouard et al. in Belcher (1998) note that intensively managed NTFP production systems may completely displace the natural vegetation within the management unit, as is frequently the case for bamboo. However, the impacts at the landscape or local level are less clear for some of the less intensively managed cases. In most cases, the ecological and biodiversity impacts have not been measured or even estimated and assessing impacts needs a clear baseline. Belcher (1998) also questions if management systems should be compared with natural undisturbed forests, with degraded forests or even agricultural fields.

Other countries offer interesting and applicable experiences concerning sustainable harvesting practices. While these encompass general, good silvicultural practices, they need to be researched and tested before implementation in Africa.

In India, guidelines have been developed for Dendrocalamus strictus (Rajahmundry 2003), and highlight that an understanding of species ecology is key to sustainable harvesting. These guidelines have been developed in Box 1. Although bamboo is a perennial species with underground rhizomes throwing up new shoots every rainy season that grow into culms, new culms may take two to three years to mature into a strong bamboo. The production of new culms in the clump depends on the vigour of the underground rhizome, its growth activity and stored food in the previous growing season. Therefore, each clump needs a sufficient number of green culms with adequate foliage to manufacture and store food in the underground rhizome. Repeated harvest reduces the productive capacity of clumps. Removal of congestion in the clumps, ensuring the underground rhizome is protected 
from rotting, fire and other damages, increases the clumps' productive capacity.

The best silvicultural system found, which satisfies all the requirements for maximum productive capacity of the clumps, is selective felling of mature culms combined with tending clumps to reduce congestion. A three-year felling cycle was found to be satisfactory to maintain productivity, with a three-month rest period in the rainy season to protect the rhizome from disturbance and prevent damage to tender bamboo shoots during the monsoon. Felling rules include three annual coupes, demarcated by natural features such as streams, tracks, block boundary lines and bridges. A culm selection system for working the bamboo coupes is recommended, where a clump is the unit of management. Mature culms are extracted depending upon the total number of mature culms and the productivity capacity of the clumps. The main objective is to ensure maximum production without impairing the clumps' vigour and to protect bamboo to ensure sustained growth and productivity.

Experiments with Guadua angustifolia in South America show that bamboo can be propagated rapidly by the 'chusquin method', where culms are cut at ground level during harvesting. This causes many small shoots and new plants to grow around the original plant. Similar findings were made by INBAR ${ }^{2}$ in China with Qiongzhuea tumidinoda (Qiongzhu). A major difficulty both regions faced was a low acceptance rate of introduced sustainable harvesting methods by harvesters, due to the reduced number of stems prescribed as harvestable in the short term. Locally adapted training and awareness raising measures were reported as essential to change habits and practices in the long term.
As bamboo can be an aggressive invader of nearby forests and land, replacing local species and often creating a less biodiverse monoculture, management and control are key measures (Kleinn 2006, Malin and Boehland 2006). Management practices include ensuring newly planted bare areas that can potentially create soil loss in erosion prone areas until well established, are covered and clumps are continually managed to limit spreading and invasion. Short term economic incentives for farmers not to overharvest include training on the benefits of soil stabilisation and product valorisation.

\section{Markets}

On a global level, by region, the biggest exporter is Asia with market share of $68 \%$, followed distantly by Europe ( $27 \%$ share), which is comprised mainly of re-exports of processed products (Table 5). Other regions have much smaller shares. The dominance of Asia is even more apparent after 2000 with its annual growth rate of $11.75 \%$ and greater market share of $68.27 \%$. Comparatively, Europe's market share and growth rate have declined. Despite its small trade, Africa's commerce has increased with an annual growth rate of $29.21 \%$ and market share of $1.59 \%$ after 2000 , compared to $12.11 \%$ growth and $0.87 \%$ market share, respectively, before 2000 . The biggest importers ranked by market share are Europe, North and Central America and Asia: comprised of mainly developed countries such as Japan and Singapore. Europe and North and Central America have increasing import shares since 2000 of $40.16 \%$ and $32.73 \%$, respectively. Consequently, Asia’s import share declined. Africa, despite being a small player, had a large annual growth of $31.38 \%$ and improved import share of $2.13 \%$; the latter larger than those of Oceania and South America (Pabuayon 2009). 


\section{Box 1. Sustainable harvest guidelines}

1. All current year culms should be retained.

2. A minimum of six culms over 1 year old, spaced uniformly over the clump should be retained. When there are large clumps, proportionately more mature culms should be retained.

3. Culms should be felled between the 1 st and 2 nd internode from ground level.

4. A sharp instrument should be used when felling to avoid splitting and damage of culms.

5. All dead and dry bamboo and high cuts should be removed first.

6. Cutting bamboo to feed livestock or otherwise is prohibited.

7. Clumps having six or less mature culms (i.e. more than one year old) should not be harvested. Only broken, dead, dry or badly damaged and twisted bamboos should be removed.

8. Rhizomes should not be damaged nor the clump uprooted.

9. All cut debris should be removed at least one metre away from the periphery of each worked clump.

10. Bamboo forests should be protected from fires, especially during the year of harvest and the year post-harvest.

11. When flowering is sporadic, all flowered clumps within working coupe, and which have shed their seed, should be clear felled.

12. When there is gregarious flowering, all clumps which have flowered, irrespective of felling cycle, should be clear felled, after the seed has been shed. The felled material should be removed. These areas should be strictly prohibited for grazing and should be fire protected at least for 5 years to ensure establishment and regeneration. Cattle proof trenches should be dug wherever needed.

13. Cutting should be prohibited in the dry season.

14. Congested bamboo clumps should be clear felled by forming segments. A maximum of three segments of congested clump may be worked, and at each working, not more than one segment will be cut. Where three segments are formed, the middle segment will be in the shape of the triangle having apex at the periphery and base formed by $1 / 3 \mathrm{rd}$ of the periphery. This segment should be felled at the first working. In subsequent cycles leftover side segments should be felled.

15. No mounding is required, only loosening of soil around the clump to ensure quick rhizome spreading

16. Training and awareness raising of owners and harvesters on the long term benefits of sustainable harvesting, including long term increased productivity, carbon sequestration and soil erosion control.

Table 4. World bamboo and rattan export and imports

Bamboo and rattan export and import COMTRADE data, 2000 (US\$1 000)

\begin{tabular}{lrrr}
\hline Commodities & HS Code & Export & Import \\
\hline Raw materials & & 128547 & 179399 \\
Bamboo & 140110 & 39602 & 59590 \\
Rattan & 140120 & 49548 & 75923 \\
Vegetable plaiting materials & 140190 & 39397 & 43886 \\
Products & & 2417839 & 2740750 \\
Plaits and products & 460110 & 17777 & 13909 \\
Mats and screens & 460120 & 219404 & 170210 \\
Plaited materialos, not mats & 460191 & 29933 & 122545 \\
Basketwork & 460210 & 713799 & 932795 \\
Seats of cane, osier & 940150 & 371366 & 423166 \\
Furniture of cane & 940380 & 1065560 & 1078125 \\
Vegetables (shoots) & & 2541748 & 2490194 \\
Vegetables, including shoots & 070990 & 1156968 & 1112536 \\
Vegetables, fresh or chilled & 071190 & 259281 & 293681 \\
Vegetables, mixed & 200590 & 1125799 & 1083977 \\
Total & & 5088134 & 5410343 \\
\hline
\end{tabular}

Source: FAO 2003 


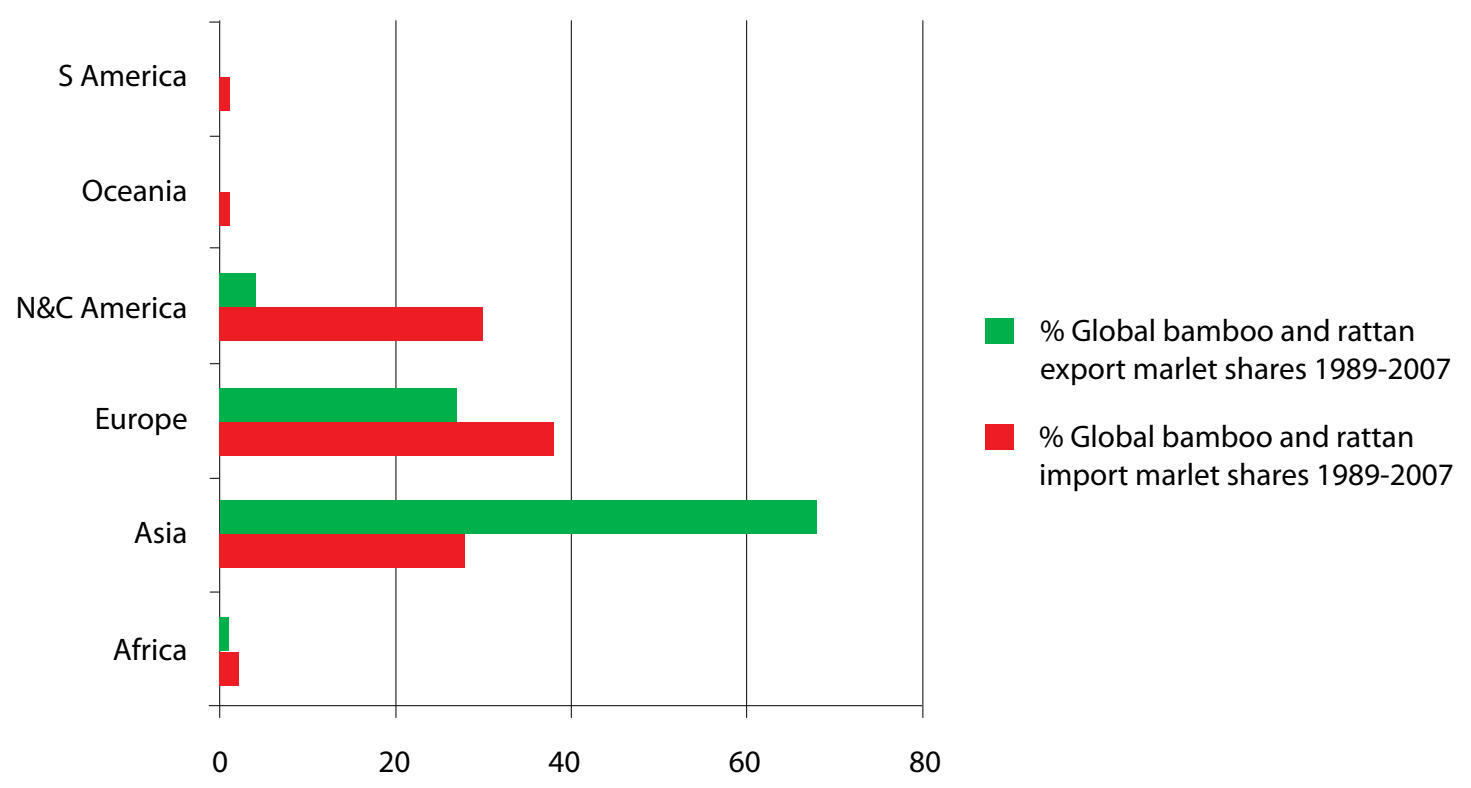

Figure 12. Global bamboo and rattan export and import market shares 1989-2007 Source: Pabuayon 2009

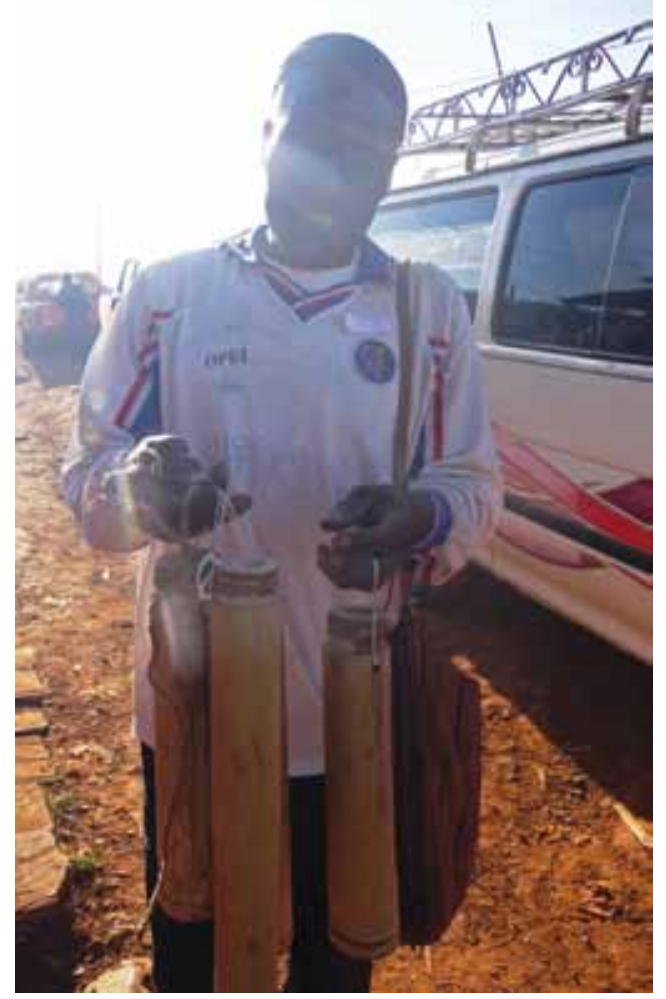

Figure 13. Bamboo market trader Yushina alpina storage 'jars', Oku, Northwest 



\section{Methodology}

\section{Definition of the Production to Consumption System}

The main method employed during this study was the Production to Consumption System (PCS). The PCS approach assesses and describes the chain of activities from the production of raw material, through various trading nodes and processing to the final consumer of derived products. According to Belcher (1995), the term 'production to consumption system' is the entire chain of activities from production of raw material through various stages of intermediate sales and processing, to the consumer of the final product. The PCS includes the technologies used to process the material as well as the social, political and economic environment in which these processes operate. The PCS concept was the framework adopted by INBAR for conducting the study. A basic principle underlying the PCS framework is the differentiation of the system flow into subsystems. This is to enable the identification and redress of the major bottlenecks hampering the optimum economic performance of any particular aspect of the system. The interventions developed to address the constraints must assist participants to overcome the constraints and increase benefits earned from their enterprises and resources. The system includes the technologies used to process the material as well as the social, political and economic environments in which these processes operate. In order to generate data specific to the bamboo sector, priority areas were defined through a stakeholder consultation process ascertained from the literature review and responses from key stakeholders (ministries, conservation and development organisations) (Appendix 1). Production areas were chosen for the collection of data on all aspects of the present state of the bamboo sector in those locations.

\section{Study areas}

Interviews were carried out primarily in five regions in Cameroon: Centre, Littoral, West, Southwest and Northwest where bamboo production, processing and utilisation are common. Additional data on species location, uses and markets was collected in two regions: Adamaoua and the East. The main data collection locations are shown in Figure 15.

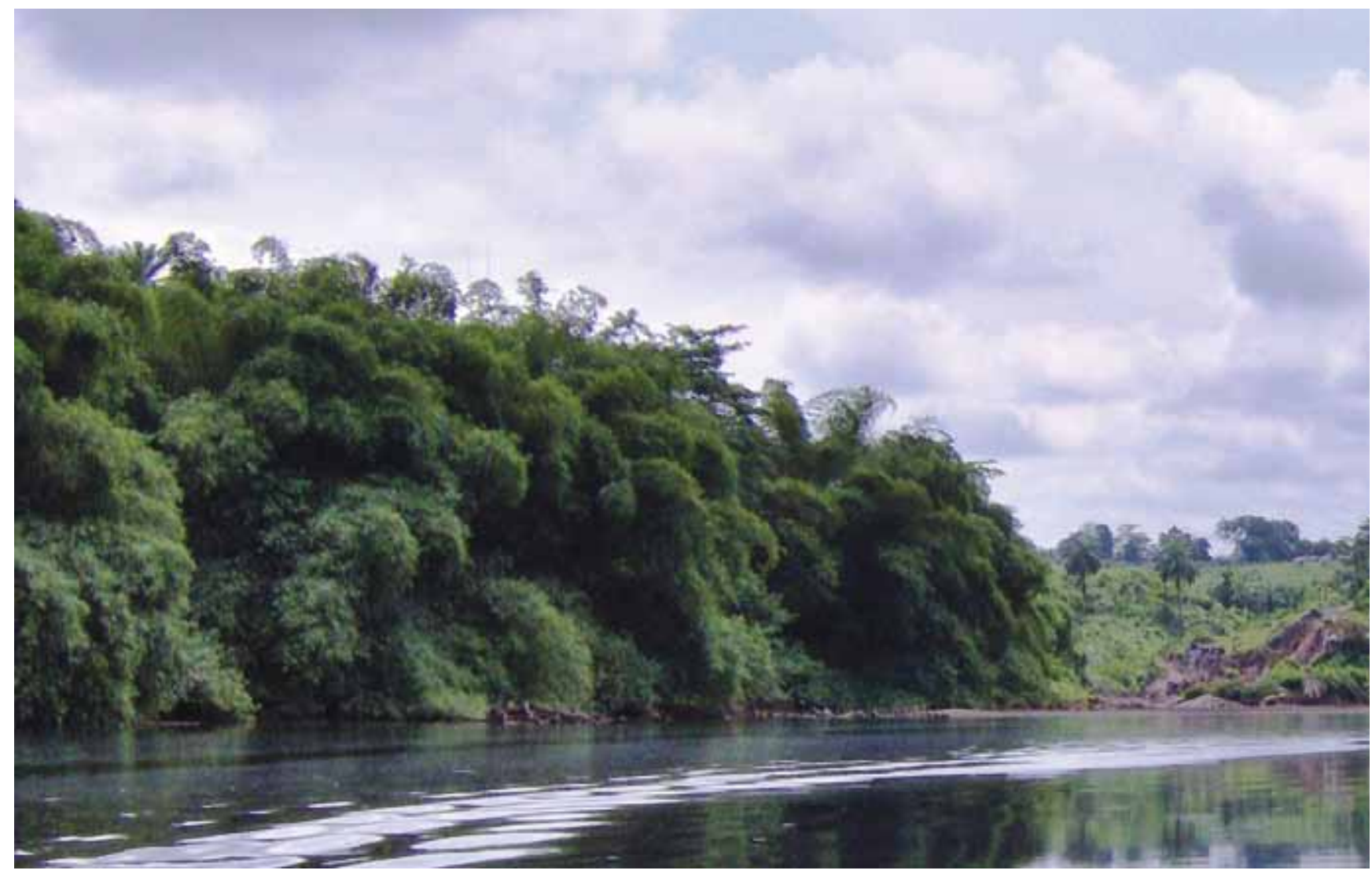

Figure 14. Bamboo (Bambusa vulgaris), Korup, Southwest 


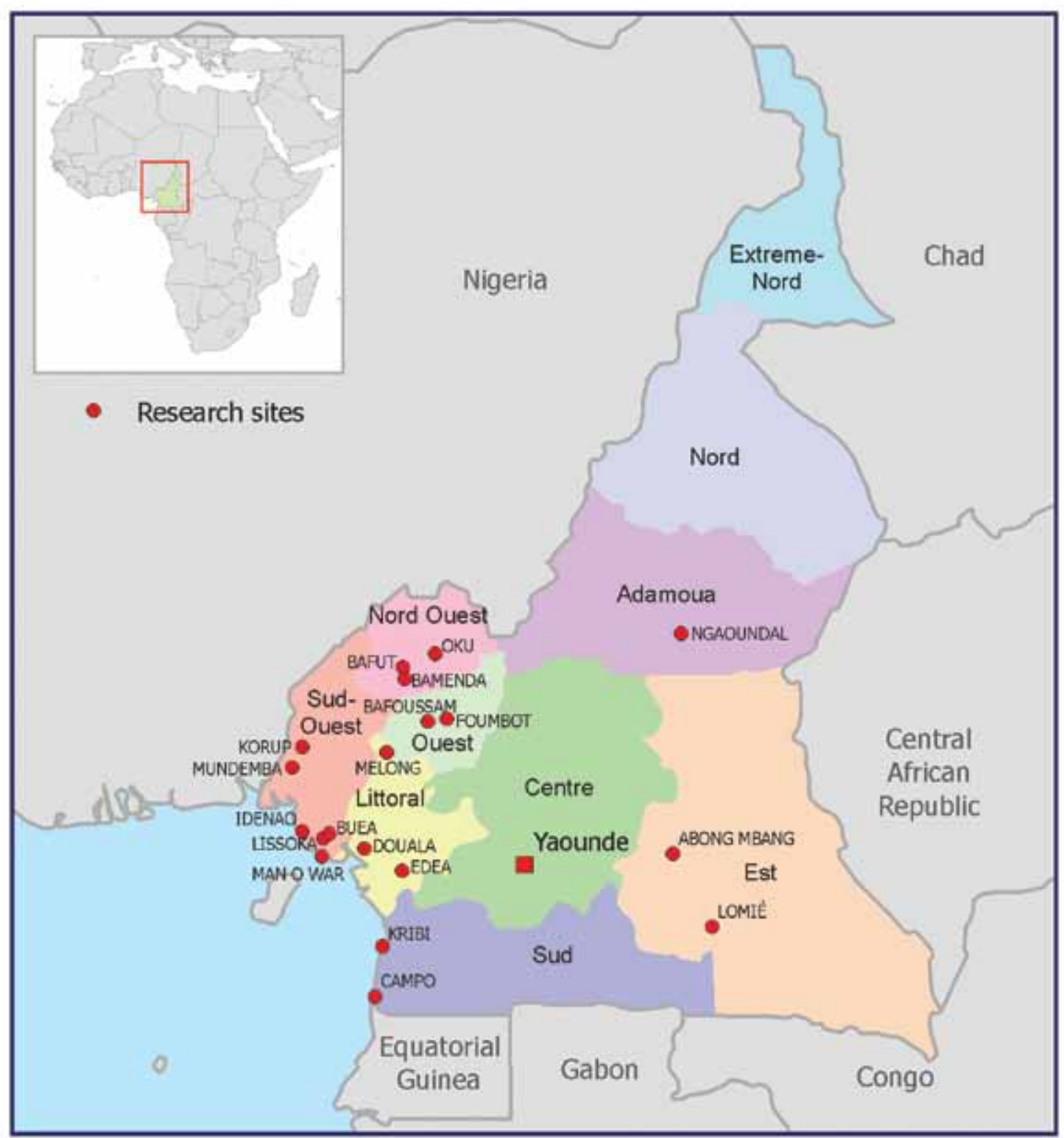

Figure 15. Map of main bamboo harvesting areas in Cameroon

\section{Data collection parameters}

General information was sought on the country (geographical, topographical, climate, demography, political, environmental); the bamboo sector (biodiversity, production, utilisation, socio-economic and marketing, legislation; the institutional capacity at the national and local level; and, previous, ongoing and upcoming research and development interventions in the bamboo sector.

As major actors in the bamboo PCS in Cameroon include rural and urban harvesters, transporters, processors, traders and consumers and support stakeholders (Figure 29), information was sought from each of group and collected using semi-structured questionnaires (Appendix 2). Field visits were made to key sites (Figure 15) for observation, consultation and focus group interviews. Actors interviewed are shown in Table 5.

\section{Sampling techniques}

At each site, collectors, traders, processors and/or consumers were randomly selected based on their willingness to collaborate in this research. Some actors in the chain, in particular processors in Douala, expressed research fatigue (they provide information to researchers but never get feedback or assistance), however most were willing to cooperate, expressing optimism that collaborating with researchers and development partners was important for the sector's improvement. 
Table 5. Bamboo PCS actors interviewed

\begin{tabular}{lcc}
\hline Actors & Number interviewed & $\%$ of total actors \\
\hline Harvesters & 39 & $15 \%$ \\
Processors & 38 & $15 \%$ \\
Traders & 31 & $12 \%$ \\
Consumers & 41 & $16 \%$ \\
Stakeholders & 112 & $43 \%$ \\
Total & 261 & $100 \%$ \\
\hline
\end{tabular}

Given the study's time and resource boundaries, the number in each group of actors interviewed was less than 40 , which represents a small sample size. It is not possible to indicate the proportion of actors in the Bamboo PCS chain that this sample represents. Instead the study aimed to cover a broader geographical area, to provide a current status of the PCS in Cameroon and a basis for future, more in-depth studies.

\section{Data analysis}

The collection of data from the field was followed by data entry (using CSPro Version 3.1 computer software), which was checked and then analysed using the Statistical Package for Social Sciences (SPSS). Descriptive statistics were mainly used, as regression analysis could not give meaningful results due to the small sample sizes. Frequency tabulation was used to present the collected information on the various aspects of the PCS. Aggregation and extrapolations were used to pinpoint the bamboo sector's importance to the livelihoods of collectors, traders and processors. Constraints and opportunities were analysed for all actors, but particularly for consumers to furnish information on the development of new products and demand. Potential solutions to the constraints identified and to take advantage of opportunities were identified for collectors, traders and processors. Equations were used to estimate the values of variables for the impact of bamboo-related activities on the livelihoods of actors, with the following equations used:

\section{Collectors' data}

(Eq. 1) Total number of bamboo collected per year = Number of trips per month*Number of bamboo collected per trip*number of months in activity per year
(Eq. 2) Total earned per year from bamboo = Total number of bamboos collected per year*unit price of bamboo

(Eq. 3) Total expenditure from hired labour $=$ Total $1+$ Total $2+$ Total 3

Where:

Total $1=$ number of trips per week* $4^{*}$ number of months worked per year* amount paid per person* number of persons paid per trip

Total 2 = number of trips per week ${ }^{*} 4^{*}$ number of months worked per year* other expenses per trip* Total 3 = expenses for royalty/fee/council tax per year

(Eq. 4) Total expenditure $=\sum$ (total expenditure $\left.\mathrm{X}\right)$ Where $\mathrm{X}=$ \{hired labour + food + clothing + house rent + school fees medical fees + entertainment + others socials expenditure\}

\section{Processors' data}

(Eq. 5) Total expenditure on raw materials $\mathrm{X}$ per year $=$ Quantity of X used per month* Unit price of $\mathrm{X}^{*}$ number of months in activity per year

Where $\mathrm{X}=\{$ Bamboo, Plywood, Nails, Glue, Vanish, Gas, Petrol and Thinner $\}$

(Eq. 6) Total expenditure on apprentices per year = Number of apprentices* Wage rate per month*number of months worked per year

(Eq. 7) Total other expenditure on Y per year = Quantity of $Y$ used per year* unit price of $Y$ Where $\mathrm{Y}=\{$ Knives, Brushes, Benches/tables, Sprayer $\}$

\section{Traders' data}

(Eq. 8) Total expenditure $=\sum$ (total expenditure $\left.\mathrm{X}\right)$ Where $\mathrm{X}=$ \{goods purchased, transportation of goods, Government taxes/levies/market tolls, store/stall rent, association dues, food, clothing, house rent, school fees, medical fess, funerals, entertainment, other social expenses\}

(Eq. 9) Total revenue $=\sum$ (total expenditure $Y$ ) Where $\mathrm{Y}=$ \{goods (bamboo), farm production, trade in other goods, government work, labourer, remittances, livestock, fishing, others\} 



\section{Results}

This section reports on the main findings of the field work, providing first an overview and then detailed information on each group of the main actors.

\section{Overview of the PCS}

\section{Actors}

Five major groups of actors are found in the bamboo PCS in Cameroon. These actors consist of individual owners of bamboo stands, collectors, processors, traders and consumers. The system in Cameroon is relatively simple with direct links between many of these groups. Indirect actors include those with authority over harvesting bamboo (village chiefs, traditional councils and councils) (Figure 16). It is notable that government authorities are largely absent in the control or regulation of the system's production side, mainly being involved in supporting traders and consumers. Also remarkable is the similarity with the rattan PCS in Cameroon (Sunderland 2001, p250).

\section{Key}

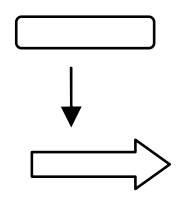

Actors

Flow of raw materials

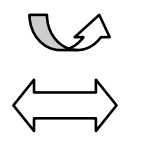

Flow of processed products through traders

Flow of processed products from processors to consumers

$\rightarrow$

Flow of raw and processed materials

Control/regulation

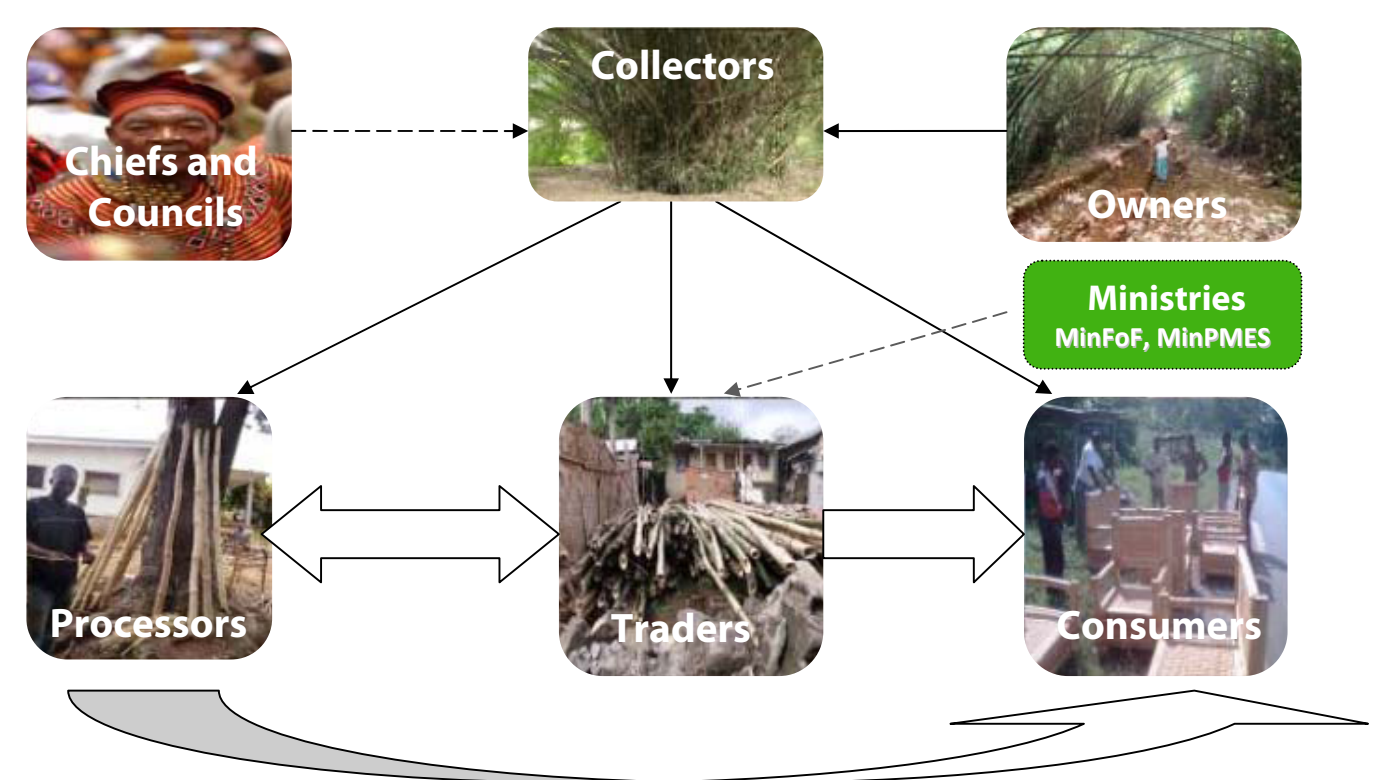




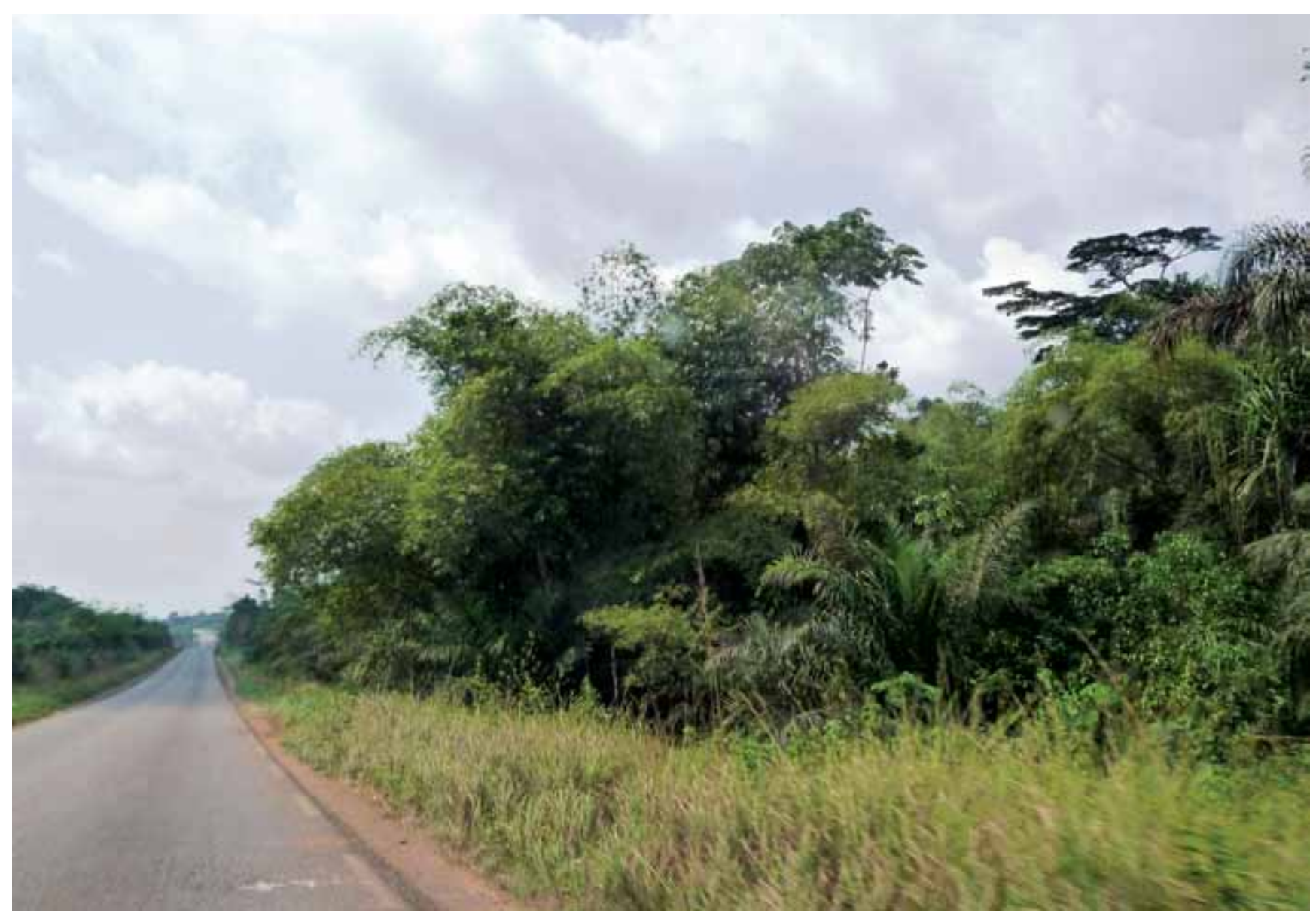

Figure 17. Bamboo (Bambusa vulgaris), Yaoundé-Edea road

\section{Location of production and consumption zones}

The review of literature and the field work highlighted the geographical areas where bamboo is found in Cameroon, its uses, the actors involved and their contacts. These are described in detail in Table 6 . The main production zones in Cameroon are shown in Figure 18, and include the Littoral region around Douala and Edea, in the Northwest around Bamenda, Bafut and $\mathrm{Oku}$, the Southwest around Limbe and the Centre around Yaoundé, with small-scale, local production and consumption in the East around the main towns such as Abong Mbang and Lomie. As the field work did not include Adamaoua, North and Extreme North, bamboo may also be found in these areas but is not included.

Interviews, particularly with key stakeholders, revealed that the non-native Bambusa vulgaris is predominately found along rivers and streams and adjacent to current or former settlements. This relation and frequent proximity can be explained by its planting during colonial times and subsequently. A number of stakeholders mentioned that the Germans were particularly influential in introducing bamboo, for agricultural use as supports/poles in plantations. The
Limbe Botanic Garden is the best documented example and still exhibits bamboo introduced by the Germans in the 1880s. It appears very likely from emerging ethnobotanic-archaeological research that the majority of bamboo throughout the coastal zone and around the major towns originates from this colonial introduction (Personal communication Marliac).

\section{Trade circuits}

As shown in Figure 20, the major and longest trade circuits flow from the production areas to the two major cities in Cameroon; in the Centre, raw bamboo and some processed products are traded from the Edea area to Douala, and from Mblamayo towards Yaoundé. There are also routes to the provincial capitals such as Kribi, Buea and Bamenda from nearby sources. The shortest local routes are from sources in the villages to local consumers e.g. in the East and in the Northwest, such as Oku.

\section{Processing}

The literature indicates that the main processing practices and technologies in Cameroon are basic. For 

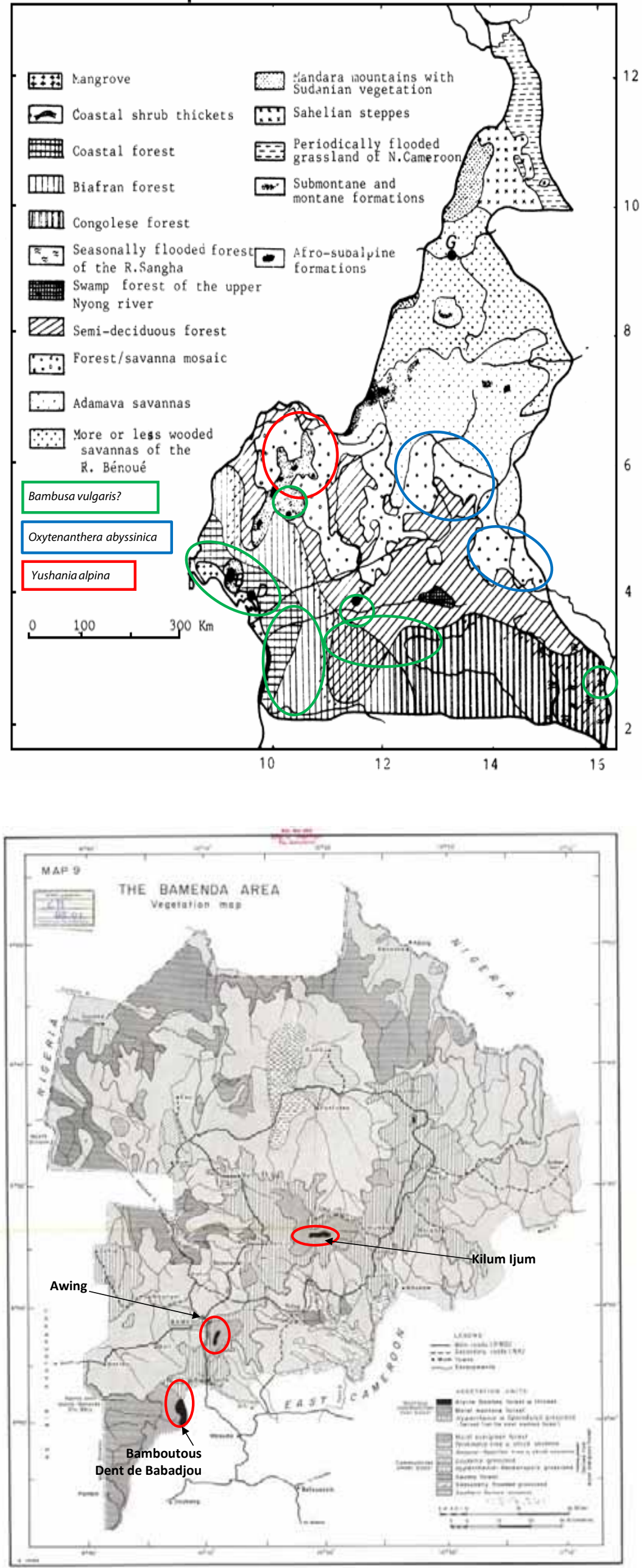

Figure 18. Major bamboo production zones in Cameroon

Source: Adapted from Letouzy 1985
Figure 19. Major bamboo production zones in the Northwest region

Source: Hawkins and Brunt 1965 


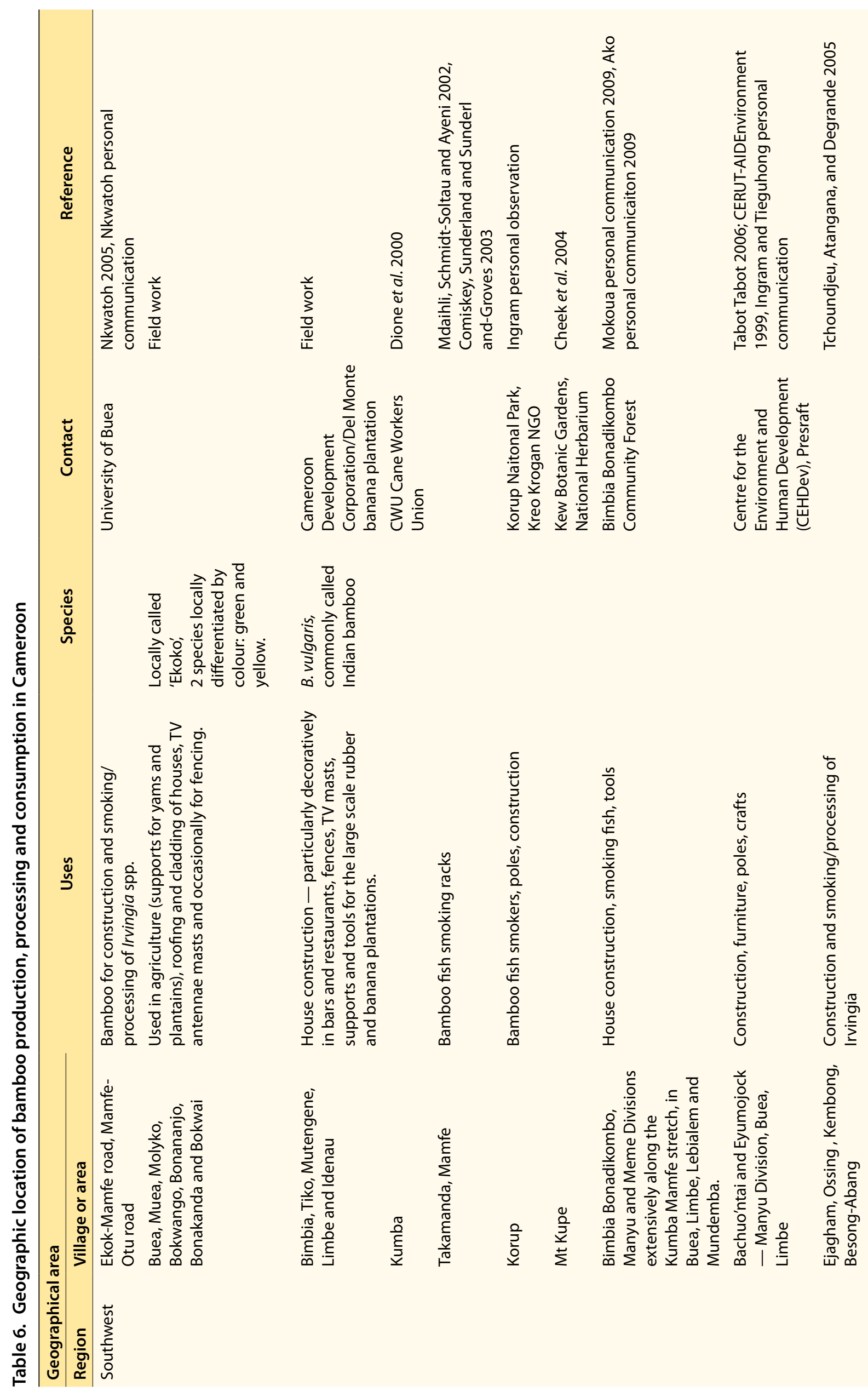




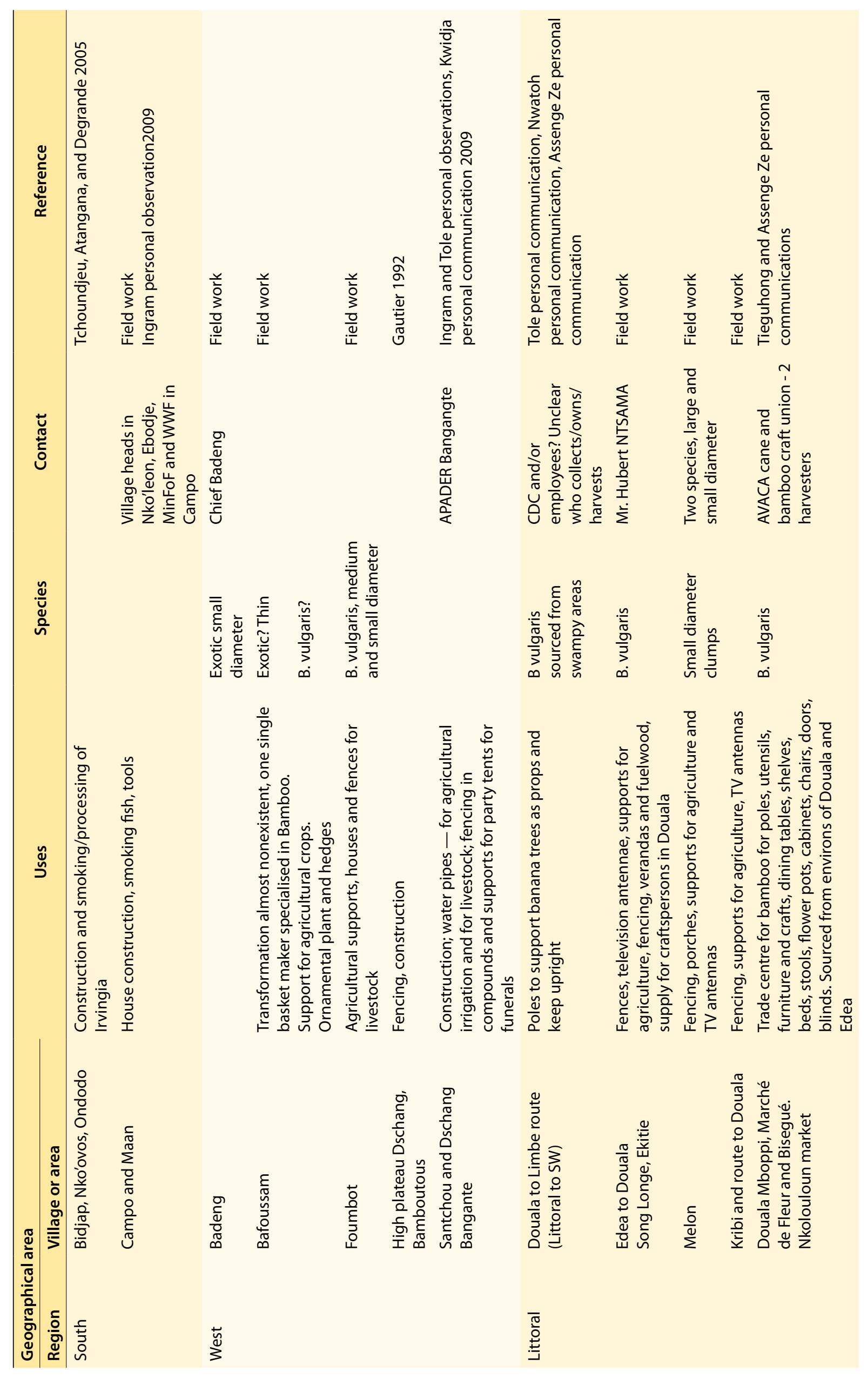




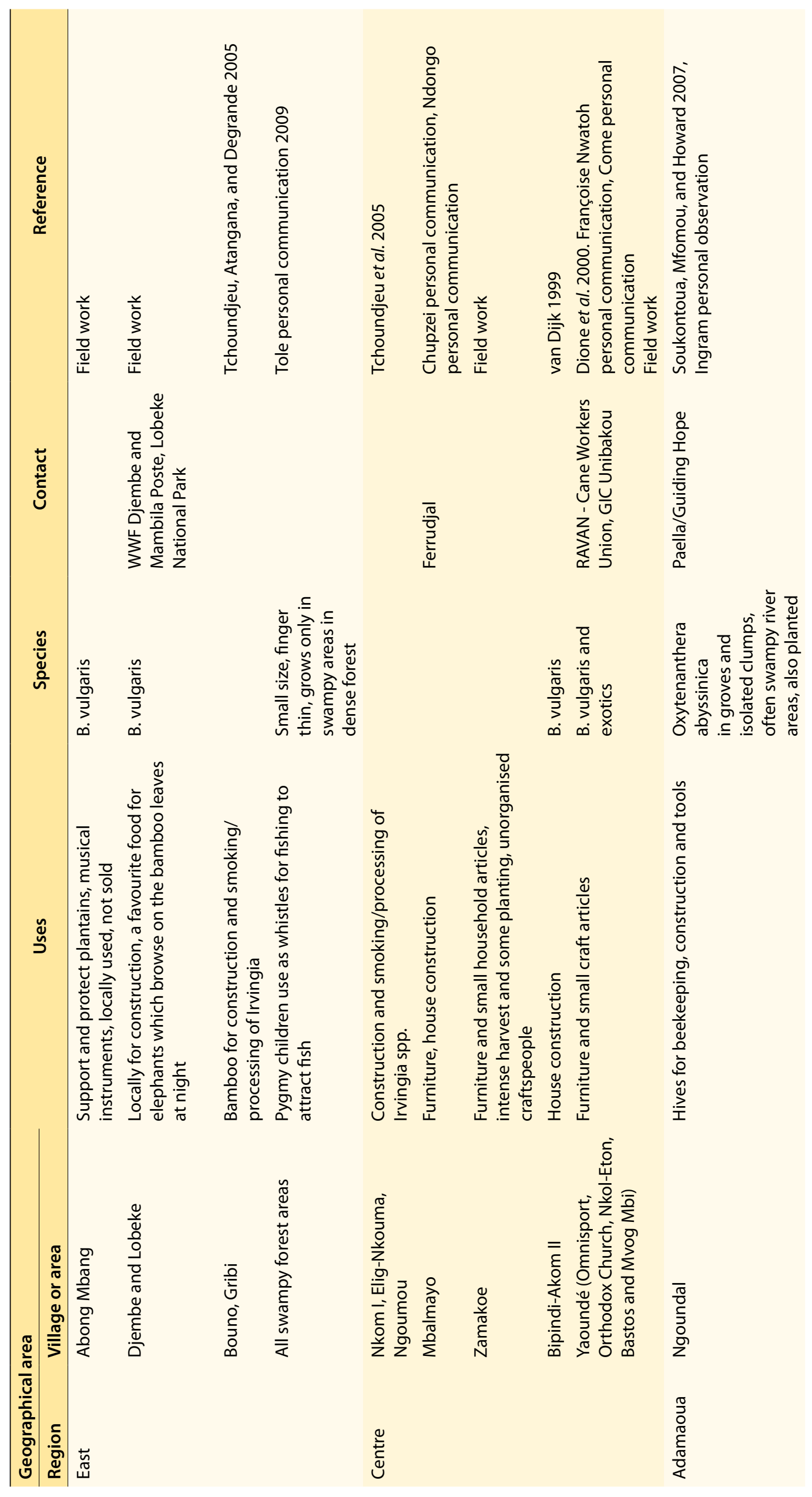




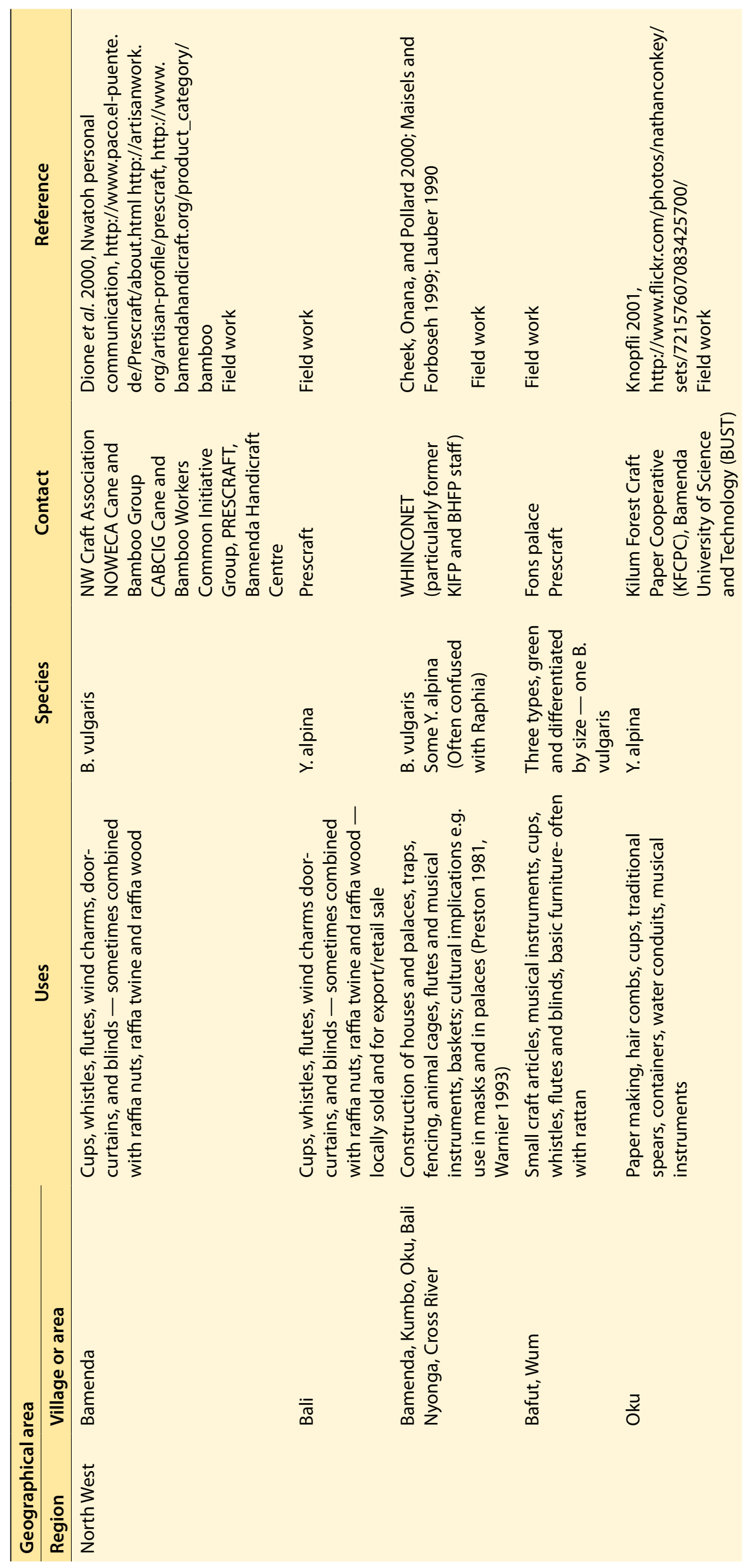




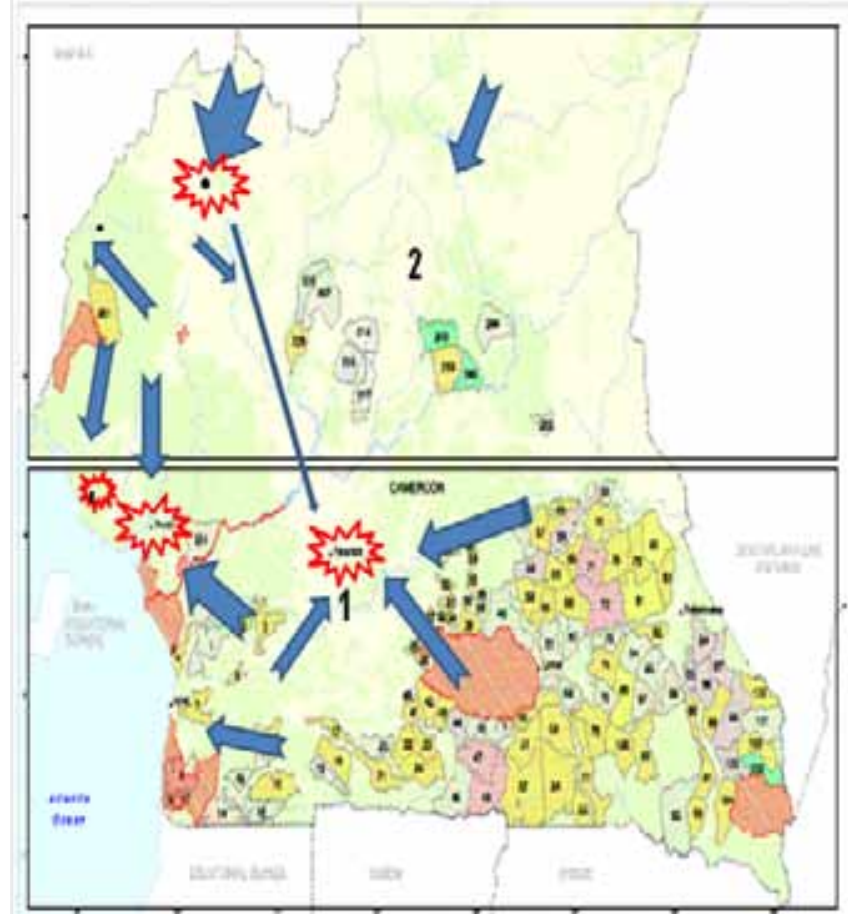

Figure 20. Major trade circuits

Source: Adapted from GFW 2005

construction use as poles and for furniture, the only processing appears to be cutting and some rudimentary air drying (in the open or under the eaves of houses).

For tools, utensils and crafts, basic (air or under eaves) drying and processing has been noted, followed by crafting, burning, carving, lacquering and fabrication — often in combination with other materials e.g. wood, rattan and metal.

In Kilum Ijum near Oku, bamboo has been used for paper making; the technology was introduced by the Kilum Ijum project in the 1990s (Nurse et al. 1995)

While a number of articles mention in passing that bamboo is used in Cameroon for construction, little specific information exists on the actual products, location or markets (Burgener 2007), with only two main types of products and their uses distinguished:

1. Where indigenous bamboo is found (notably in the Northwest and Adamaoua), there is a longer history of use, particularly for house construction, and infrastructure such as water conduits/ pipes and containers (beehives). Recorded use of bamboo dates back about 60 years to the British colonial administration period (Kaberry 1952) for firewood, and diverse products including household tools, traps, baskets and traditional rucksacks, crafts and musical instruments.

2. Where introduced bamboo is found, it is used mainly for the most 'obvious' use of construction, furniture and a variety of tools, containers and utensils. However, even given at least a 30-year

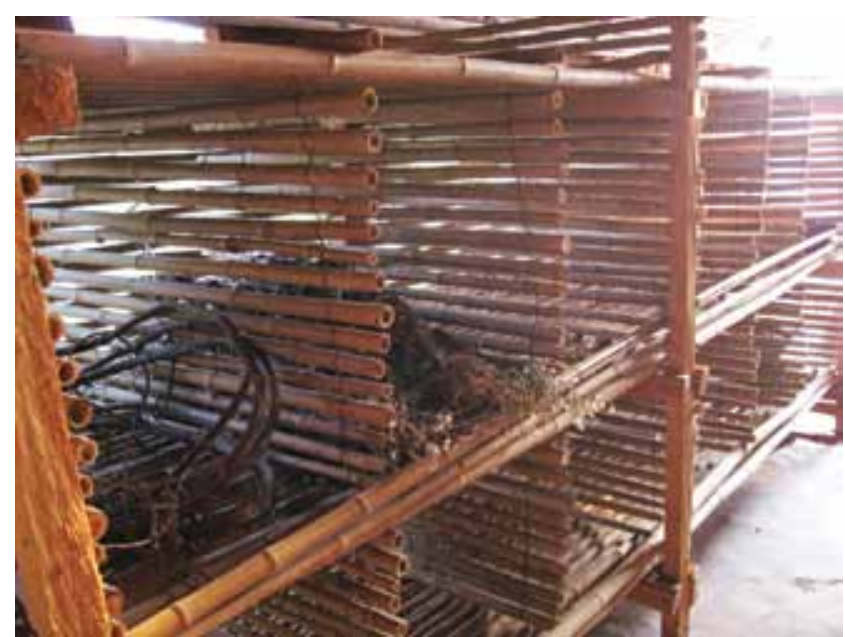

Figure 21. Bamboo herb drying rack, Babungo, Northwest

history of use for construction (Mundi 1978), the range of bamboo products produced in Cameroon is narrow when compared with Asia.

The level of processing found in the literature review was confirmed during the field work, as predominantly basic two-stage processing (Figure 22). Primary processing is conducted largely by the processors themselves and consists of cutting and drying. During the drying process, infestation and storage can be a problem with several processors (particularly in the more humid and wetter areas such as Edea and Oku) reporting losses due to rot or insects. The secondary processing stage is to transform bamboo directly into products though carving, carving, fabrication, lacquering and, the most complex process encountered, into paper. The range of processed products typically is limited to specialisation - with very few producers creating a wide range of different products. Thirteen groups of bamboo products, totalling 44 product types, are created in Cameroon (Box 2).

\section{Stakeholders}

The major stakeholders in the chain are shown in Figure 14, and can be classified into four main groups:

1. Active: Owners, harvesters/collectors, producers/ craftspersons and traders/retailers.

2. Passive: Regulatory, support and control by the government could currently be described as passive with no active policies or regulation by competent ministries such as the Ministry of Forestry and Wildlife (MINFOF), the National Agency for Reforestation (ANAFOR) or the Ministry of Agriculture and Rural Development (MINADER). Within the craft sector, the Ministry of Small and Medium Enterprises provides some indirect support for production from small and medium 


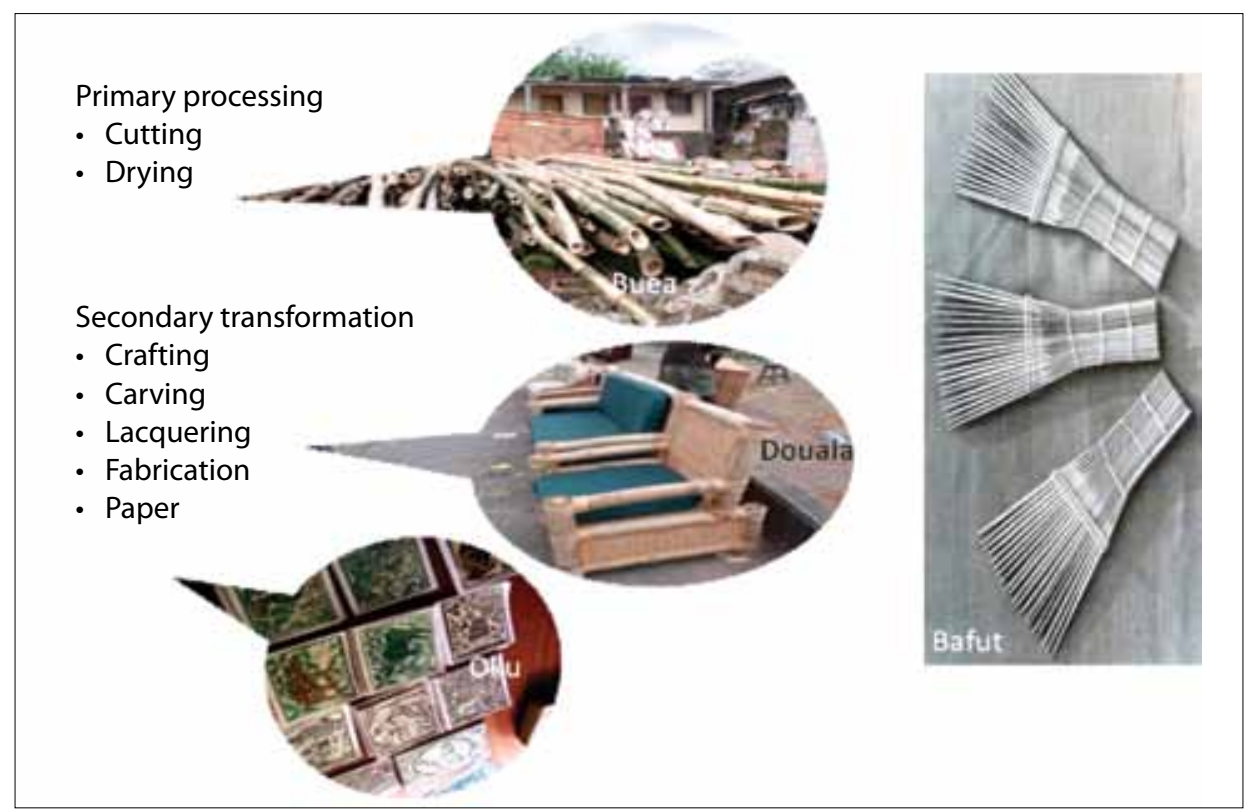

Figure 22. Bamboo processing in Cameroon

\section{Box 2. Bamboo products produced in Cameroon}

1. Furniture (tables, stools, chairs, sofa, beds, shelves, cupboards, racks, hanging screens)

2. Fencing and hedges (live and poles)

3. Construction material (poles, house supports, doors, scaffolding, roofing, ceilings, wall cladding, TV aerial/ antenna masts)

4. Utensils (combs, drying racks, smoking racks [fish and Irvingia spp.], cups, containers, soya sticks, small tools and handles)

5. Baskets and containers (food containers, flower pots, beehives)

6. Hunting implements (spears, traps, cages, bow and arrows)

7. Agriculture supports (beans, bananas and rubber)

8. Water pipes

9. Musical instruments (whistles, flutes, rattles, wind chimes)

10. Ornamental and decorative planting

11. Fuelwood

12. Paper

13. Food (wild animals, particularly elephants)

crafts enterprises, but this is not specifically for bamboo. No regulation or standards apply to consumption e.g. furniture standards or safety of bamboo scaffolding.

3. Unconnected: This group of stakeholders is present or active in Cameroon and possesses technical knowledge and skills concerning bamboo, and related topics such as agroforestry, but members are currently not active in the sector or have no or little connection with other stakeholders, specifically on the topic of bamboo.

4. Absent: No development or support organisations are currently working in the sector. In the past, the

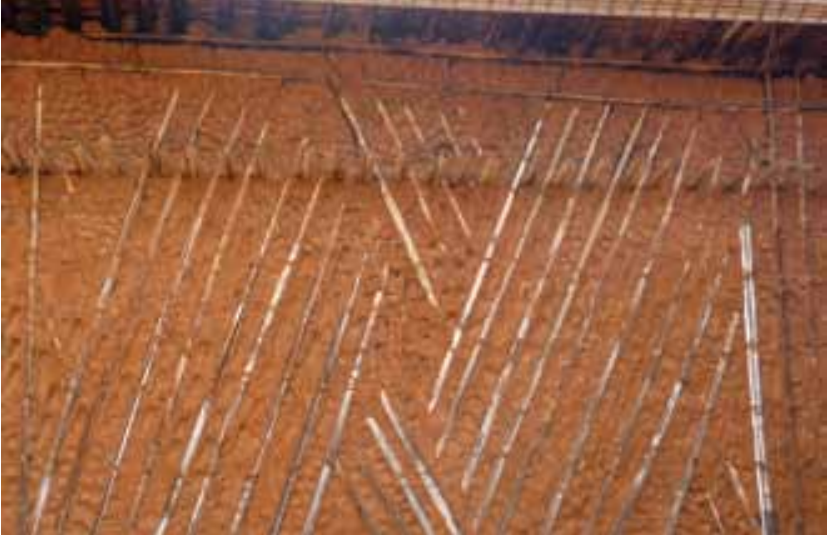

Figure 23. Bamboo and mud wall, Oku, Northwest

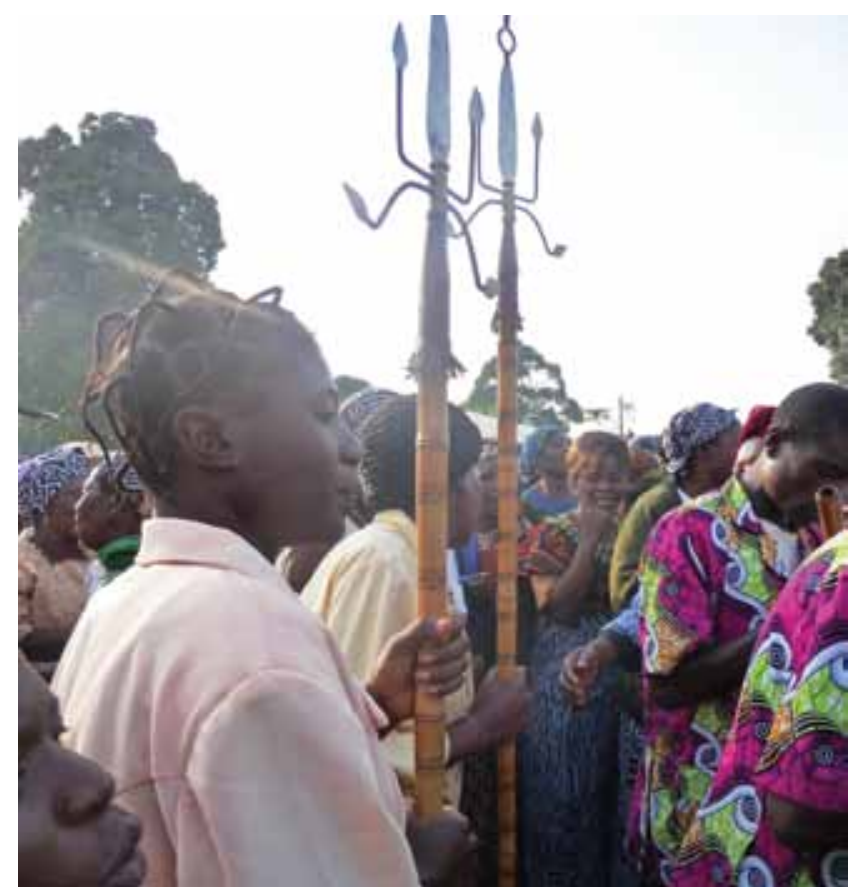

Figure 24. Traditional bamboo spear, Oku, Northwest 


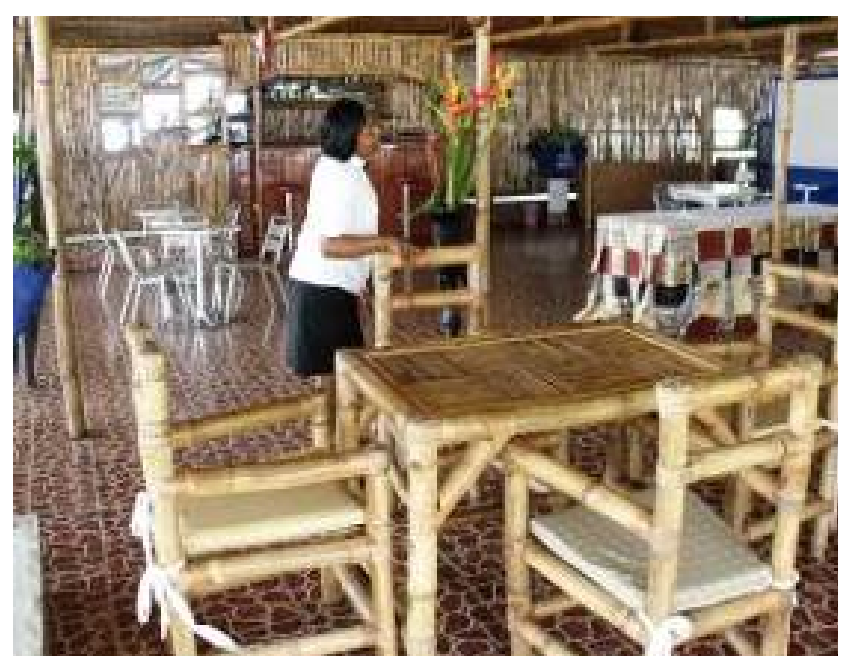

Figure 25. Bamboo clad restaurant and furniture, Buea, Southwest

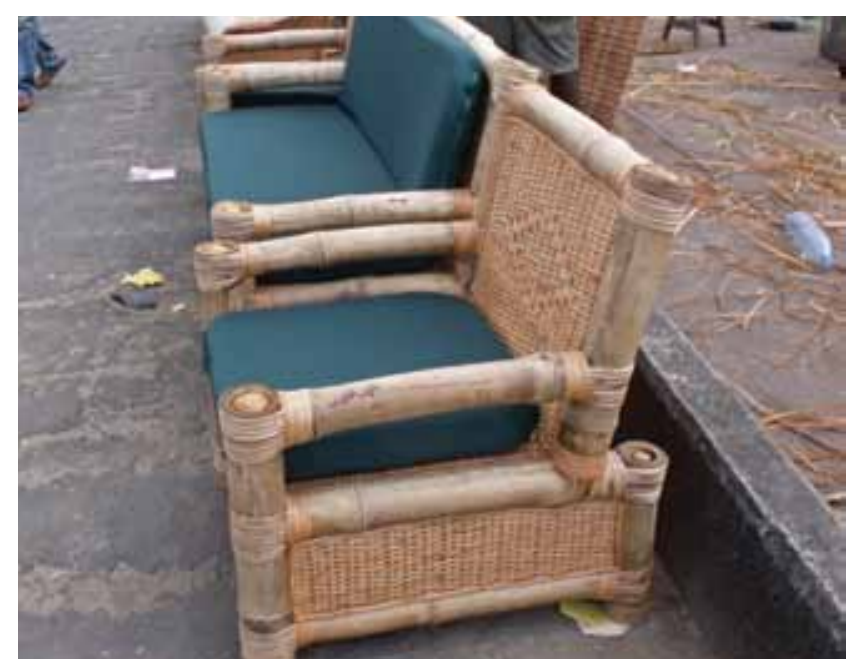

Figure 26. Bamboo and rattan chairs, Douala, Littoral

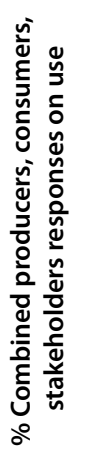

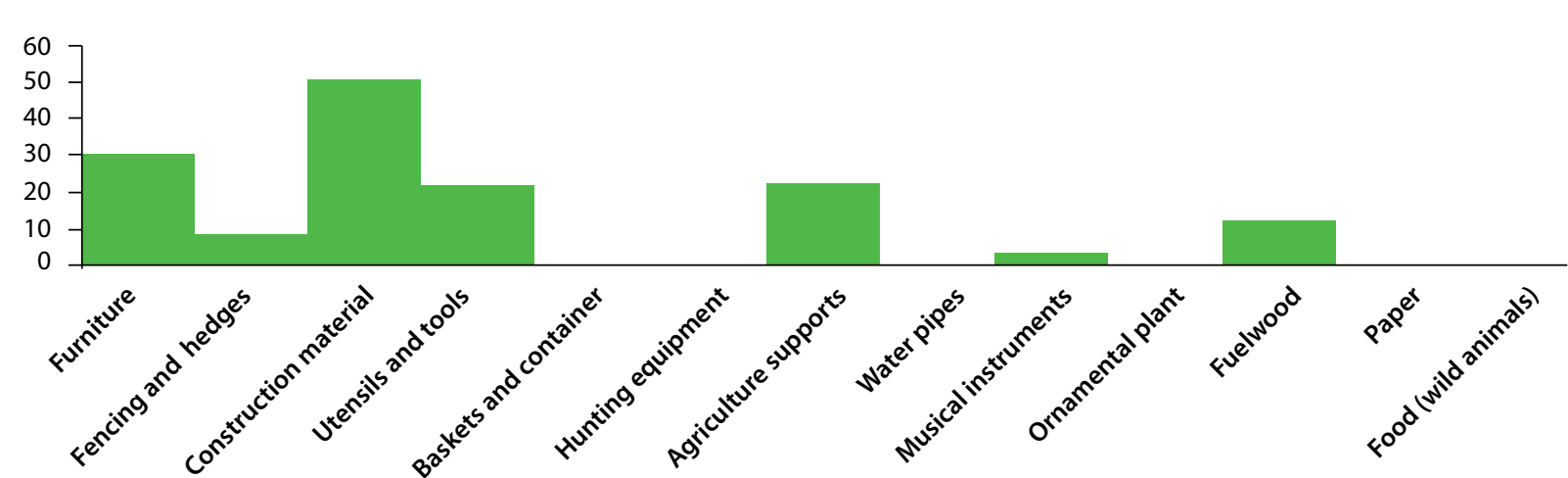

Major uses and products type of bamboo

Figure 27. Frequency of bamboo product types/uses in Cameroon
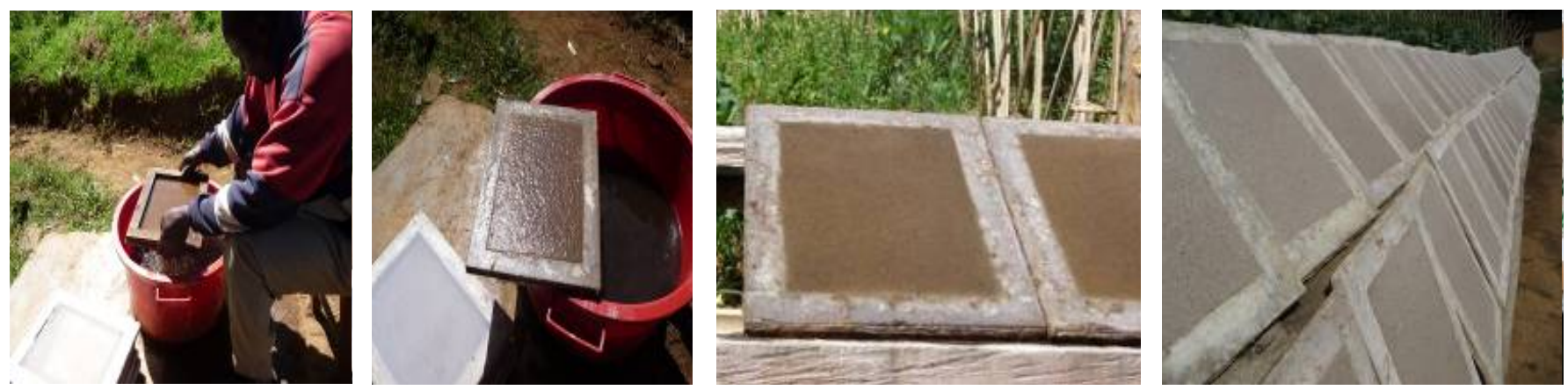

Figure 28. Bamboo based paper making process, Oku, Northwest 


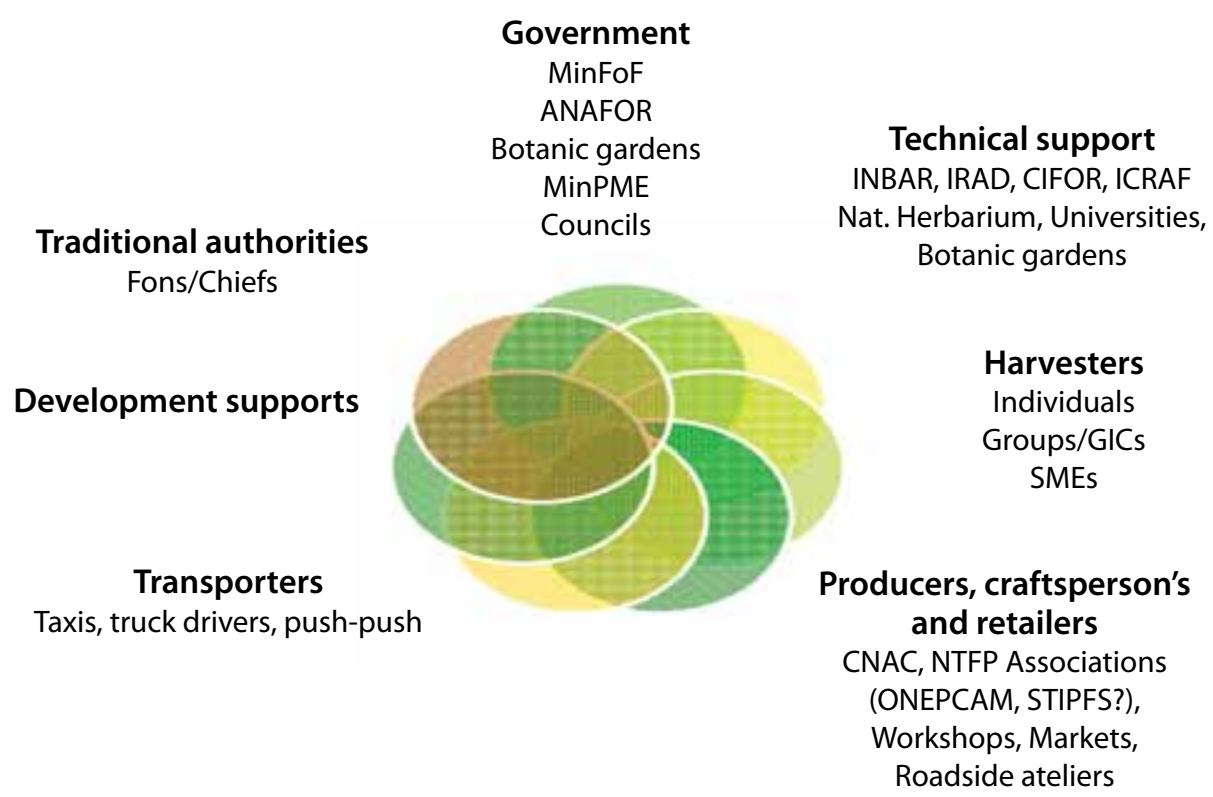

Figure 29. Stakeholders in the bamboo PCS Cameroon

only known development stakeholder was the paper making expert from the Kilum Ijum Forest Project in Oku around 2000.

\section{Actors in the PCS}

\section{Bamboo harvesters}

\section{Socio-demographic profile of harvesters}

In the five regions of Cameroon, 39 bamboo collectors were interviewed: $36 \%$ from the Southwest, 3\% in the Northwest, $18 \%$ in Littoral, $10 \%$ in the Centre and $33 \%$ in the West regions.

Most of the bamboo collectors were males (90\%); 85\% of the collectors were native to the collection area, while $15 \%$ were migrants. In general, harvesters have a low level of education, with 13\% having no formal education and only 3\% with a university education, as shown in Table 7.

\section{Income generation sources for bamboo harvesters Farming was the major source of revenue for $56 \%$ of harvesters, with bamboo contributing to $18 \%$ of household incomes (Figure 30).}

Slightly more than a quarter (26\%) of harvesters classify bamboo collection as their major occupation or activity, alongside farming (23\%), unskilled labour (10\%) and herbal practices (10\%) (Figure 31).

Analysis of the number and gender of household members involved in bamboo collection (Table 8) indicates that the number of men, women, boys and girls in a given household varied from $1-5$ (mean=1.28,
$\mathrm{SD}=0.83), 0-7($ mean $=0.51 ; \mathrm{SD}= \pm 1.3), 0-7$ (mean=0.31; $\mathrm{SD}= \pm 1.24)$, and 0-2 $($ mean $=0.05 ; \mathrm{SD}=$ \pm 0.32 ) respectively. Most bamboo collectors (77\%) asserted that bamboo covered less than $33 \%$ of their community land. The estimated land area covered by bamboo in each community varied from 1-20 ha with a mean of 6.05 ha $(S D=4.94 \mathrm{ha})$, totalling 115 ha.

\section{Description of the bamboo harvest system}

\section{Land tenure and access to bamboo}

The harvesting of bamboo is carried out in a team, comprising the harvester and transporters. The majority of bamboo is open access (69\%) and not 'owned' by individuals unless it is found on their land (31\%) (Table 9).

For collectors who own bamboo stands, the size varied from 1-20 ha, with a mean of 9.25 ha $(S D= \pm 4.99$ ha $)$. When bamboo is owned it is usually a grove claimed by a village or individual, sometimes physically with a sign, such as in Nko'oleon near Campo-Maan national park and Bimbia Bondadikondo community forest near Limbe in the Southwest. Around the Southwest towns of Buea and Limbe, and villages of Muea, Molyko, Bokwango, Bonananjo, Bonakanda and Bokwai, bamboo harvesting is free, but verbal authorisation from the landowner or caretaker must be sought. In Muea consumers also buy from neighbouring villages. When asked who controlled or owned the bamboo land, $62 \%$ of the harvesters said the land belonged to the landowner, $21 \%$ indicated it belonged to the chief and $8 \%$ said that bamboo land was the property of everybody in the community (Figure 32 ). 
Table 7. Education level of harvesters

\begin{tabular}{lcc}
\hline Educational status & Frequency & Percentage \\
\hline None & 5 & 13 \\
Primary & 19 & 49 \\
Middle & 4 & 10 \\
Secondary school & 10 & 26 \\
University & 1 & 3 \\
Total & 39 & 100 \\
\hline
\end{tabular}

Concerning harvesting rights, $56 \%$ of collectors stated that only local people from the area were permitted to harvest bamboo, while $44 \%$ indicated that anyone could. According to the harvesters, access to bamboo harvest rights in their communities could be by permission (48.72\%), negotiation (25.64\%), open access $(17.95 \%)$ and purchase $(7.95 \%)$. Payment for collection was made in the form of royalties (33\%), rent $(15 \%)$, council tax $(11 \%)$ or a proportional commission based on quantity collected (7\%). The total amount of money paid per year as rent, tax, royalty or commission ranged from zero to $21000 \mathrm{CFAF}$, with mean of 7537 CFAF (SD $= \pm 6566$ CFAF), totalling 203500 CFAF for 27 collectors. In terms of proportion, $44 \%$ of this amount was paid to chiefs, $28 \%$ to land owners, $22 \%$ to councils and $6 \%$ to compensate collectors' family members. Most collectors (39\%) were of the opinion that the payments were cheap, $28 \%$ thought payments were reasonable while $33 \%$ considered such payments to be exorbitant.

Access to bamboo differed between harvesters. The majority (45\%) were of the opinion that they did not need to pay to collect bamboo, as it is considered to be the property of the whole community. However, 22\% indicated that bamboo was invasive and was destroying agricultural land, thus collecting it constitutes a 'fight' against the extension of the area of community or personal land covered by bamboo, and $22 \%$ believed that bamboo was under-valorised in their community, while $11 \%$ had social ties with the chief, which permitted them to harvest freely.

\section{Management and control of bamboo stands}

When collectors were asked how bamboo stock in their area was regenerated, $57 \%$ stated naturally, $6 \%$ planted and $28 \%$ indicated both natural and planted. In terms of local regulatory mechanisms and practices that govern the management of available stock, collectors mentioned that only the chief authorised harvesting $(46 \%)$, only people with long experience in bamboo harvesting were allowed (46\%) and a small 8\% said that open harvesting was permitted.

\section{Level of harvesters association}

The harvesting of bamboo is most often made up of a team (collectors and transporters); however these people usually work together and share payment, or work for a fixed fee, but do not share profits. Of the 39 collectors interviewed, only $13 \%$ belonged to an association related to bamboo. A total of five associations were mentioned by collectors in the five regions studied. Membership varied from two to 60 people, with a mean of 27 people ( $\mathrm{SD}=26$ people), totalling 134 people for the five associations. Sixty per cent of associations were mainly for collectors while $40 \%$ also included some processors. These associations (names were not registered by enumerators) were created between 1985 and 2009, including two created in 2002. A cross-table of the type of association and its objectives showed that collectors formed associations with the intention to develop and render the bamboo sector more dynamic. Improving living standards and the dynamics of the bamboo sector were the reasons for creating or joining processors' associations (Table 10).

For collectors within associations, the benefits gained or expected from the associations included acquiring capital (60\%), easier access to raw materials $(20 \%)$ and assistance to build a house (20\%).

\section{Seasonality and quantity of bamboo collected}

Most bamboo collectors (51\%) harvest bamboo throughout the year. Others harvested only in the dry season (44\%) while 5\% harvested in the rainy season only. The approximate number of months spent in collecting bamboo per year ranges from 2 to 12 months, with a mean of 8 months ( $\mathrm{SD}=4.4$ months). The number of trips per month varied from once a month to every day with a mean of nine trips $(\mathrm{SD}=8.05$ trips per month). The duration of a bamboo collection trip varied from 30 minutes to 12 hours, with mean of 4.08 hours ( $\mathrm{SD}=2.74$ hours). The number of bamboo stems harvested per collector also varied from a minimum of five to a maximum 6000 bamboo stems with a mean of 601 bamboo stems $(S D=1144$ bamboo stems). For the 39 bamboo collectors, a total of 23425 bamboo stems was collected per year.

Totalling the number of bamboo stems collected per year indicates that most collectors harvest on a smallscale. The majority of collectors (74\%) harvest less than 500 bamboo stems per year while about $8 \%$ harvest more than 2000 bamboo stems per year. The species collected and the number of stems collected showed that most collectors that harvested large green bamboo actually harvested less than 500 bamboo stems per year. Those that harvested small-sized bamboo tended to harvest more than 1000 bamboo stems per year (Table 11).

\section{Species preferences and reasons}

The most common bamboo species were large, dark green bamboo (B. vulgaris) (74\%), followed by small-sized green bamboo (16\%) (the species was not 


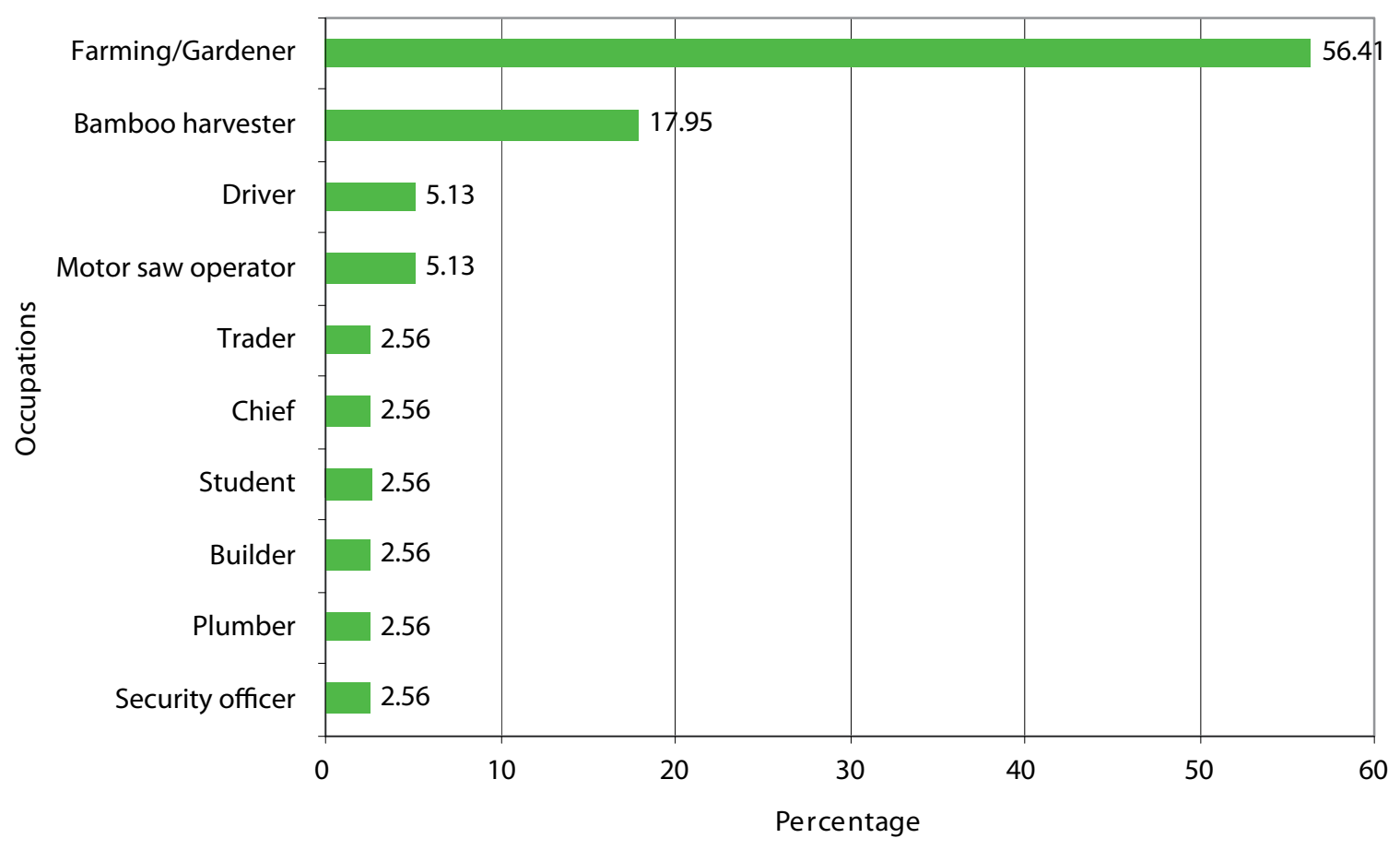

Figure 30. Sources of income for bamboo harvesters

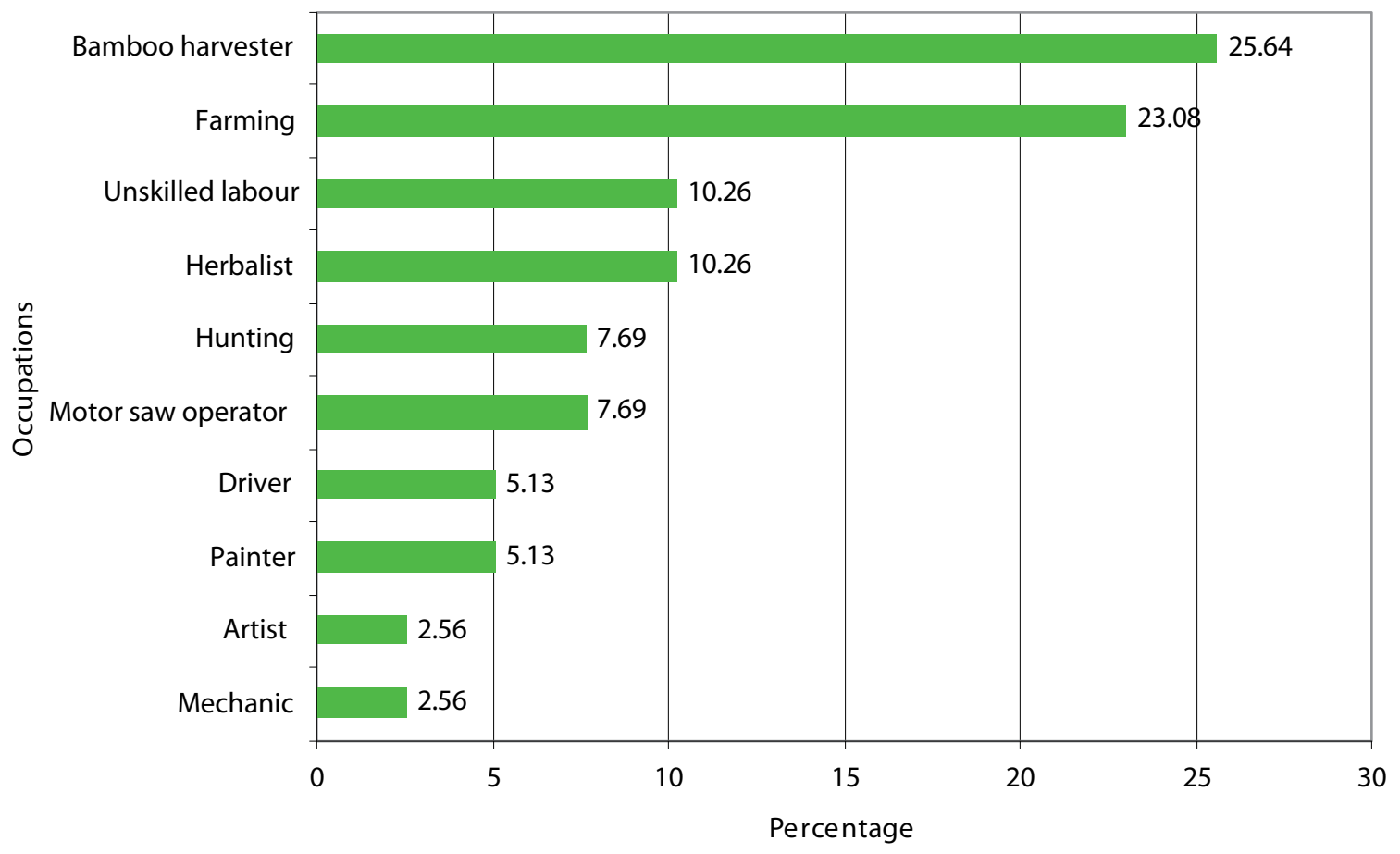

Figure 31. Stated profession of bamboo harvesters 
Table 8. Socio-economic profile of harvesters

\begin{tabular}{lrrrrrr}
\hline Variables & N & Minimum & Maximum & Sum & Mean & Std Deviation \\
\hline Age of respondent & 39 & 19 & 84 & - & 44.03 & 17 \\
Gross income major occupation per month & 39 & 5000 & 300000 & 1774000 & 45487 & 50559 \\
Gross income minor occupation per month & 20 & 5000 & 80000 & 669000 & 33450 & 22975 \\
Household size & 39 & 1 & 47 & 265 & 6.79 & 8 \\
Men $>15$ years & 39 & 0 & 10 & 82 & 2.10 & 2 \\
Women $>15$ years & 39 & 0 & 12 & 81 & 2.08 & 2 \\
Children: boys $<15$ years & 39 & 0 & 8 & 50 & 1.28 & 2 \\
$\quad$ girls $<15$ years & 38 & 0 & 17 & 53 & 1.39 & 3 \\
Number and gender of household members & 39 & 1 & 11 & 81 & 2.08 & 3 \\
involved in bamboo co & 39 & 1 & 5 & 50 & 1.28 & 0.8 \\
Men & 39 & 0 & 7 & 20 & 0.51 & 1 \\
Women & 39 & 0 & 7 & 12 & 0.31 & 1 \\
Children: boys $\quad 39$ & 0 & 2 & 2 & 0.05 & 6.05 \\
$\quad$ girls & 19 & 1 & 20 & 115 & 5 \\
Approximate area community land (ha) & & & & 5 \\
\hline
\end{tabular}

Table 9. Ownership status of bamboo stands per region

\begin{tabular}{lcccc}
\hline \multicolumn{5}{c}{ Do you own any bamboo? } \\
\hline Region & Yes & No & Total & $\begin{array}{c}\text { Percentage of } \\
\text { total respondents }\end{array}$ \\
\hline Southwest & 7 & 7 & 14 & 36 \\
Northwest & & 1 & 1 & 3 \\
Littoral & 1 & 6 & 7 & 18 \\
Centre & 2 & 2 & 4 & 10 \\
West & 2 & 11 & 13 & 33 \\
\hline Total & 12 & 27 & 39 & 100 \\
\hline Percentage & 31 & 69 & 100 & \\
\hline
\end{tabular}

determined), yellow bamboo (B. vulgaris variety vittata) and medium-sized green (species not determined, probably B. vulgaris) bamboo (5\% each).

The most preferred bamboo species (Figure 33) were the large green 'Indian' bamboo (41\%), medium-sized green bamboo (13\%), small-sized bamboo (23\%) and yellow bamboo (23\%). The reasons stated included attractiveness (28\%), availability (28\%), ease of transportation (21\%) higher demand (18\%) and higher resistance $(5 \%)$ (Table 12). This may also be linked to availability, as these are the most common species.

\section{Harvesters quality criteria}

Collectors identified six quality criteria: maturity, age, height, resistance to insects and rotting, size and the colour of leaves (Table 13).

Collectors mainly differentiate between species by colour, size or diameter $(62 \%)$ and by colour alone $(38 \%)$. According to the collectors, the length of bamboo harvested varied from 3-20 m, with an average of $7.15 \mathrm{~m}(\mathrm{SD}=3.65 \mathrm{~m})$.

The tools and inputs required for bamboo harvesting include both commonly used tools, such as a cutlass (used by $100 \%$ of harvesters), and more specialist utensils such as files (used by 39\%) and saws (3\%). According to harvesters, bamboo harvesting is a threestep procedure: making the area accessible, looking for mature bamboos and then carefully cutting. Harvesters perform repeat harvests in the same area. However, only $26 \%$ of harvesters were aware of a sustainable harvesting method for bamboo (defined by harvesters as not destroying the total plant and roots). The remainder of harvesters were not aware of this term's meaning.

\section{Distance to harvest sites and transport methods}

Head-portering was the most common means of transporting bamboo, reported by $85 \%$ of harvesters; $13 \%$ used vehicles while $3 \%$ used motorbikes.

The distance from the village to the bamboo resource varied from $1-20 \mathrm{~km}$, with an average of $3.23 \mathrm{~km}$ $(\mathrm{SD}=3.83 \mathrm{~km})$.

After collection, bamboo was normally stored near the harvester's house $(36 \%)$, at the place of harvest in the forest $(33 \%)$, transported to the village centre $(26 \%)$ or assembled in a school premise (5\%).

The amount spent per person in collecting bamboo per trip varied from 200-3000 CFAF, with an average of 1132 CFAF (SD=919 CFAF). The total amount spent by 17 harvesters per trip was 19250 CFAF. The number of people in a bamboo collection team varied from one to nine, with mean of three $(\mathrm{SD}=1.82)$, totalling 115 people for the 39 collectors. 


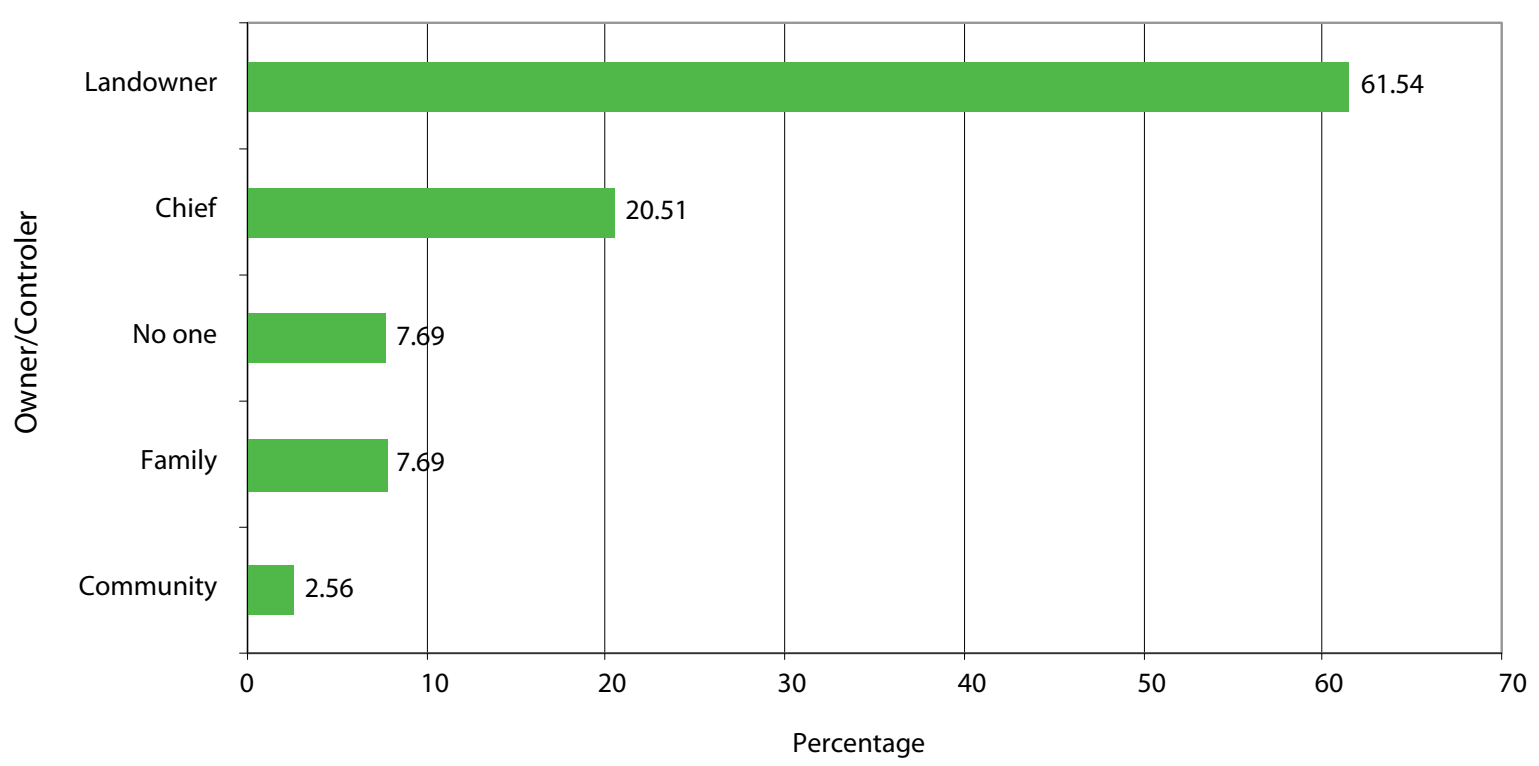

Figure 32. Land ownership status

Bamboo harvesting was financed from three sources: advanced payment from clients (47\%), sales of farm products $(41 \%)$ and sales of handicrafts $(12 \%)$. The majority $(64 \%)$ of harvesters reported that sometimes they reject stems; on average seven bamboo stems $(\mathrm{SD}=10)$, with a wide range from one to 50 bamboos, were rejected totalling 166 stems per trip by 25 collectors. The main reasons included immaturity (56\%), accidental harvest such as unintended cutting of stems, often due to poor tools (28\%) and bad quality (16\%).

\section{Own consumption and factors influencing harvest}

Some $77 \%$ of collectors used at least some of the bamboo for their own household use. About $80 \%$ used it to construct huts, fences, yam props, supports for plantain and bananas, etc. Seven factors affect the quantity of bamboo harvested per giving period, most importantly accessibility (33\%), followed by resource availability and demand (18\%) (Figure 34). The season and labour availability were also significant factors, whereas the quality, infestation and snakebites were the least deterrents. The type of disease or infestation observed include unspecified insects (67\%), stains (23\%) and rot or decay (10\%).

\section{Markets for bamboo}

Bamboo collectors largely sell their bamboo in local markets (41\%), at home (28\%), at collection point $(21 \%)$ and in urban markets $(10 \%)$. The main buyers are processors (44\%), farmers for agricultural use $(23 \%)$, middlemen (18\%) and builders (15\%). Direct cash payment prevails as the main purchasing arrangement for $62 \%$ of transactions, followed by advance payment (33\%) and credit (5\%). Around Buea and Limbe, collectors consume a proportion themselves and sell upon demand to clients who are mostly bricklayers in Buea and Muea, who use the bamboos for scaffolding.

\section{Contribution of bamboo to harvesters' livelihoods}

The annual total net household income for the 39 bamboo collectors interviewed was 9899425 CFAF. There was, however, a wide variability, ranging from $700 \mathrm{CFAF}$ to $2700900 \mathrm{CFAF}$, with an average of 252 $831 \mathrm{CFAF}(\mathrm{SD}=447927 \mathrm{CFAF})$.

The vast majority (79\%) of collectors were satisfied with the income they earned from bamboo harvesting; but $72 \%$ had no idea whether bamboo grading could command a better price. Only $15 \%$ of harvesters also

Table 10. Types of harvesters associations and objectives

\begin{tabular}{lcccc}
\hline Main objective of this association & Type of bamboo association & $\begin{array}{c}\text { Total } \\
\text { Processors }\end{array}$ & $\begin{array}{c}\text { Percentage of } \\
\text { respondents }\end{array}$ \\
\cline { 2 - 5 } & Collectors & 1 & 4 & 80 \\
\hline $\begin{array}{l}\text { Develop and dynamise the bamboo sector } \\
\text { Improve living standard of members }\end{array}$ & 3 & 1 & 1 & 20 \\
Total & 3 & 2 & 5 & 100 \\
$\%$ of respondents & 60 & 40 & 100 & \\
\hline
\end{tabular}


Table 11. Quantity of stems harvested per year and species

\begin{tabular}{|c|c|c|c|c|c|c|c|}
\hline \multirow{2}{*}{ Bamboo species } & \multicolumn{5}{|c|}{ Total number of bamboo stems harvested annually } & \multirow{2}{*}{ Total } & \multirow{2}{*}{$\begin{array}{l}\text { Percentage of } \\
\text { respondents }\end{array}$} \\
\hline & $0-500$ & $1000-1500$ & $1500-2000$ & $500-1000$ & $>2000$ & & \\
\hline $\begin{array}{l}\text { Large green } \\
\text { (B. vulgaris) }\end{array}$ & 25 & 1 & & 2 & 1 & 29 & 74 \\
\hline Medium sized green bamboo & 1 & & 1 & & & 2 & 5 \\
\hline Small sized green bamboo & 1 & 2 & & 1 & 2 & 6 & 15 \\
\hline $\begin{array}{l}\text { Yellow bamboo } \\
\text { (B. vulgaris) }\end{array}$ & 2 & & & & & 2 & 5 \\
\hline Total & 29 & 3 & 1 & 3 & 3 & 39 & 100 \\
\hline$\%$ & 74 & 8 & 2 & 8 & 8 & 100 & \\
\hline
\end{tabular}

Table 12. Preferred bamboo species and reason

\begin{tabular}{|c|c|c|c|c|c|c|c|}
\hline \multirow[b]{2}{*}{ Most preferred species } & \multicolumn{5}{|c|}{ Reason } & \multirow[b]{2}{*}{ Total } & \multirow{2}{*}{$\begin{array}{l}\text { Percentage of } \\
\text { respondents }\end{array}$} \\
\hline & $\begin{array}{l}\text { Higher } \\
\text { demand }\end{array}$ & Attractive & Availability & $\begin{array}{l}\text { More } \\
\text { resistant }\end{array}$ & $\begin{array}{c}\text { Easily } \\
\text { transported }\end{array}$ & & \\
\hline $\begin{array}{l}\text { Large green } \\
\text { (B. vulgaris) }\end{array}$ & 2 & 5 & 6 & 1 & 2 & 16 & 41 \\
\hline Medium-sized green bamboo & 3 & 2 & 2 & & 2 & 9 & 23 \\
\hline Small-sized green bamboo & 1 & 2 & 1 & 1 & & 5 & 13 \\
\hline $\begin{array}{l}\text { Yellow bamboo } \\
\text { (B. vulgaris) }\end{array}$ & 1 & 2 & 2 & & 4 & 9 & 23 \\
\hline Total & 7 & 11 & 11 & 2 & 8 & 39 & 100 \\
\hline$\%$ & 18 & 28 & 28 & 5 & 21 & 100 & \\
\hline
\end{tabular}

Table 13. Factors determining bamboo quality

\begin{tabular}{lcc}
\hline Factor & Frequency & $\begin{array}{c}\text { Percentage of } \\
\text { respondents }\end{array}$ \\
\hline Maturity & 17 & 44 \\
Resistance to insects & 4 & 10 \\
Age & 7 & 18 \\
Height & 7 & 18 \\
Size & 3 & 8 \\
Leaves (colour) & 1 & 3 \\
Total & 39 & 100 \\
\hline
\end{tabular}

processed part or all of their harvest into other products: the majority sold only raw bamboo.

Eight income portfolios were identified in the household revenues of bamboo collectors. Annual household income from bamboo varies widely ranging from 1625 CFAF to 2880000 CFAF, with a mean of 236208 (SD=467 712 CFAF). This variability was consistent for all income sources and is shown in Table 14. The primary source of collectors' household income was from bamboo (36\%), followed by agriculture (32\%).

\section{Household expenditures}

Among the work-related expenditures, hired labour/tax/area rents incurred during bamboo collection were the largest source of expenditure $(60 \%)$ followed by purchasing food (Table 15).

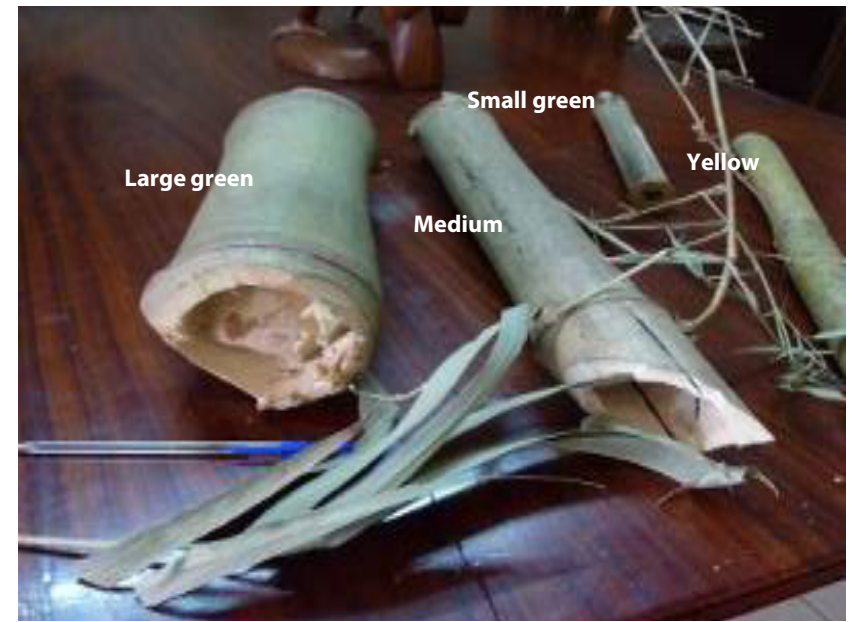

Figure 33. Samples of bamboo species found in Cameroon

\section{Processors}

\section{Socio-demographic profile of processors}

A total of 38 processors, also known as craftsmen, all males, were interviewed. The majority $(87 \%)$ were native to the area of activity and $13 \%$ were migrants. More than $80 \%$ of those interviewed were in the Littoral and Centre regions of Cameroon (Table 16).

The educational status of processors is generally slightly higher than collectors, with $3 \%$ of processors 


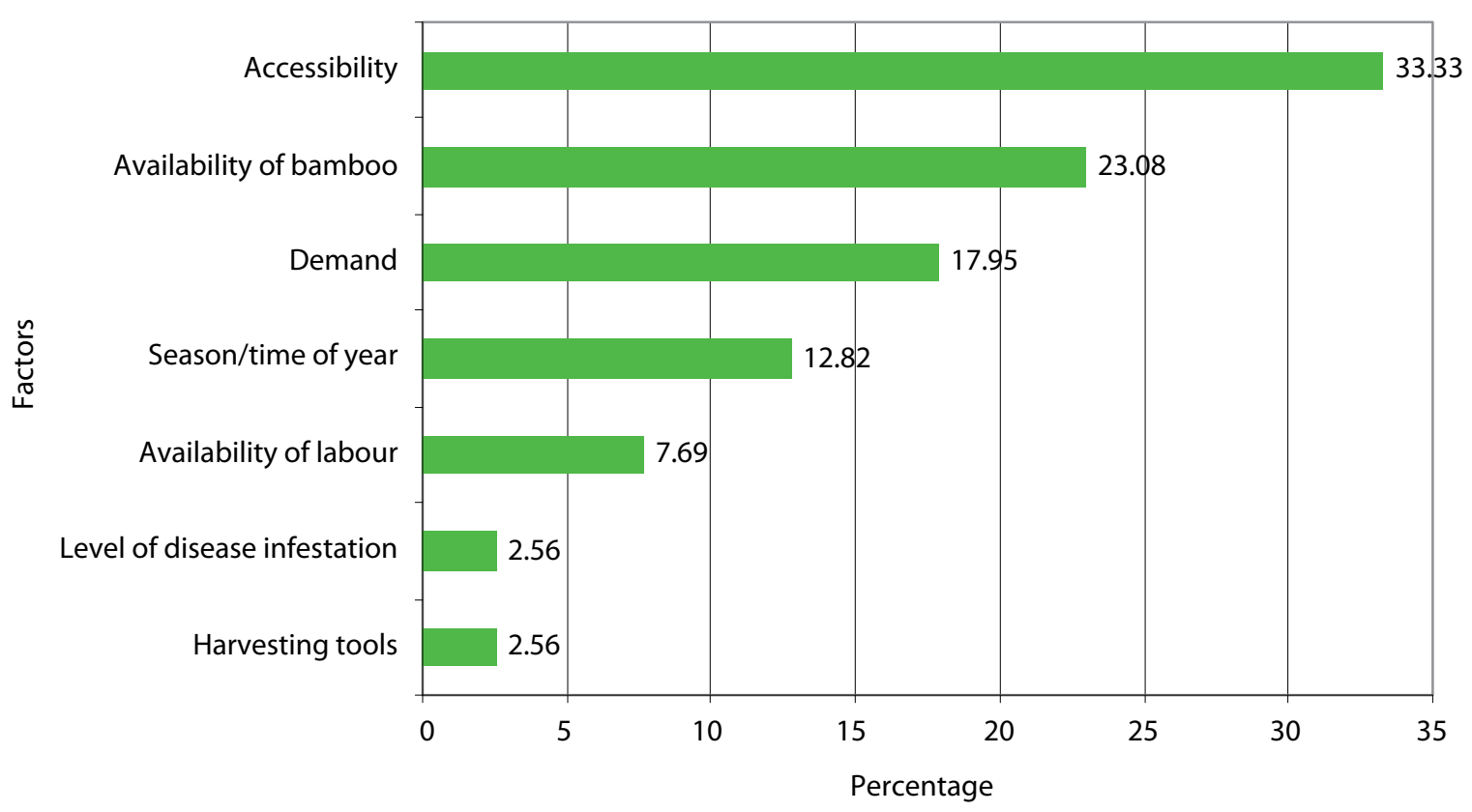

Figure 34. Determinants of quantity of bamboo harvested

having no formal school while 53\%, 16\%, 24\% and $5 \%$ respectively had primary, middle, secondary or university education. Their ages ranged from 19 to 38 years old with a mean of $36(\mathrm{SD}= \pm 10.9$ years). Similar to processors, $32 \%$ were single and $68 \%$ married. On average, processors have been in the sector for 11 years with a large variation from 1-30 years $(\mathrm{SD}= \pm 6.9$ years $)$

Crafts were the main source of income for processors, followed by farming (Table 17), indicating the high level of specialisation in this profession.

The mean household size for a processor is 5.55 inhabitants $(\mathrm{SD}=3.37)$, varying from one to 14 people. The average amount of time processors have been working in the sector is 11 years $(\mathrm{SD}=6.9$ years), with a wide range from 1-30 years. No entry barriers into the bamboo processing business were identified, as most processors are motivated by their friends ( $21 \%)$, because they lack alternative employment opportunities $(18 \%)$ or are encouraged by an expatriate (5\%) (Figure 35).

\section{Source of bamboo}

Processors in Yaoundé mainly obtain get their bamboo within $40 \mathrm{~km}$ from the city centre along the route to Mblamayo, including Bankolo, Nsimalen, Soa, Nkolbison, Nkol-mefou I, Mokombou, Nkol-Afamba and Ekali II. Processors in Douala sourced their bamboo from the collection centre at Nkololoun market, which in turn comes from around Edea. Foumbot was a major source of bamboo for processors in the West region while Wum and community lands in Bafut constitute the major sources of in Bamenda. Bamboo in Oku was sourced from bamboo forest zones in the Kilum-Ijum forest, and, in the
Southwest, Man-O-War Bay is a major source for the Muea market in Buea.

\section{Organisation of bamboo processing enterprises}

An analysis of the position of processors within their enterprise indicates that $76 \%$ owned their workshops, $16 \%$ were assistants, $5 \%$ were chief assistants/ apprentices and $3 \%$ were overseers/supervisors.

Only $13 \%$ of the workshops were legally registered. This situation of informal, small enterprises is comparable to other sectors in Cameroon, notably NTFP processors and harvesters and small processors and crafts, where the majority operate informally (Northwest Crafts Association personal communication, Ingram 2009). Among those that were registered, $40 \%$ were registered with the Chamber of Commerce, while $40 \%$ were Common Initiative Groups - a legal form of small enterprise in Cameroon - such as GIC FARMROLI (20\%) and APVF/GIC PROFOPEC (20\%). A fifth $(20 \%)$ of organisations were registered with the Ministry of Small and Medium Scale Enterprises (MinPME). An example is the association of processors, Prescraft Bafut, where processors come together to share ideas and organise the market for their products. People from other villages come here and buy young bamboo for transplanting in their villages.

The majority of processors work alone, with only $32 \%$ belonging to an association or group (Table 18).

Most of the associations (83\%) were composed of processors, while $17 \%$ also included some collectors. These associations have been created between 1985 and 2009, although half (50\%) were created in 2009. This can be attributed particularly to awareness raising campaigns, particularly around Douala, by 
Table 14. Income sources for bamboo harvesters

\begin{tabular}{lrrrrrrr}
\hline Source of revenue & N & $\begin{array}{c}\text { Minimum } \\
\text { (CFAF) }\end{array}$ & $\begin{array}{c}\text { Maximum } \\
\text { (CFAF) }\end{array}$ & $\begin{array}{c}\text { Mean } \\
\text { (CFAF) }\end{array}$ & $\begin{array}{c}\text { Std } \\
\text { (CFAF) }\end{array}$ & \multicolumn{1}{c}{$\begin{array}{c}\text { Sum } \\
\text { (CFAF) }\end{array}$} & $\begin{array}{c}\text { Percentage of total } \\
\text { revenue }\end{array}$ \\
\hline Bamboo & 39 & 1625 & 2880000 & 236208 & 467712 & 9212125 & 36 \\
Farming & 39 & 10000 & 800000 & 209064 & 224612 & 8153500 & 32 \\
Trading & 17 & 10000 & 960000 & 198823 & 255756 & 3380000 & 13 \\
Remittance & 39 & 0 & 500000 & 39102 & 87741 & 1525000 & 6 \\
Livestock & 15 & 5000 & 240000 & 89400 & 78895 & 1341000 & 5 \\
Labourer & 24 & 2000 & 100000 & 33291 & 27928 & 799000 & 3 \\
Timber company & 4 & 34000 & 600000 & 198500 & 270522 & 794000 & 3 \\
Hunting & 6 & 16000 & 78000 & 51000 & 23849 & 306000 & 1 \\
Summary & 183 & 0 & 2880000 & 131923774 & 112341 & 25510625 & 100 \\
\hline
\end{tabular}

Table 15. Harvesters' expenditure

\begin{tabular}{|c|c|c|c|c|c|c|}
\hline Source of expense & $\begin{array}{l}\text { Minimum } \\
\text { (CFAF) }\end{array}$ & $\begin{array}{l}\text { Maximum } \\
\text { (CFAF) }\end{array}$ & $\begin{array}{l}\text { Mean } \\
\text { (CFAF) }\end{array}$ & $\begin{array}{l}\text { Sum } \\
\text { (CFAF) }\end{array}$ & $\begin{array}{c}\text { Std } \\
\text { (CFAF) }\end{array}$ & $\begin{array}{c}\text { Percentage of total } \\
\text { expenditure }\end{array}$ \\
\hline Hired labour, tax and rent & 7200 & 1951000 & 264115 & 10300500 & 383077 & 60 \\
\hline Food & 20000 & 300000 & 128231 & 5001000 & 71615 & 29 \\
\hline School fees & 0 & 60000 & 12654 & 493500 & 14553 & 2 \\
\hline House rent & 0 & 120000 & 12462 & 486000 & 29759 & 2 \\
\hline Clothing & 2000 & 30000 & 10846 & 423000 & 6643 & 2 \\
\hline Medical fee & 1000 & 30000 & 7644 & 298100 & 7150 & 2 \\
\hline Entertainment & 0 & 10000 & 1951 & 76100 & 2840 & 0.4 \\
\hline Other expenses & 0 & 10000 & 487 & 19000 & 2126 & 0.1 \\
\hline Summary & 0 & 1951000 & 54798 & 17097200 & 98436 & 100 \\
\hline
\end{tabular}

Table 16. Distribution of bamboo processors by region

\begin{tabular}{lcc}
\hline Region & Frequency & Percentage of respondents \\
\hline Southwest & 4 & 11 \\
Northwest & 1 & 3 \\
Littoral & 17 & 45 \\
Centre & 15 & 39 \\
West & 1 & 3 \\
Total & 38 & 100 \\
\hline
\end{tabular}

MinPME encouraging and informing on the benefits of setting up craftspersons' associations (Eben personal communication). The most common objectives of associations include valorising bamboo processing and promoting bamboo products (Table 19).

The main benefit derived or expected from collective action and joining a processors' association, is the exchange of ideas and experiences during meetings, seminars and training sessions (Table 20).

\section{Processed bamboo products and bamboo species used}

The materials used in processing are locally purchased, with common tools being machetes, saws, hammers, rulers and nails.
Large 'Indian bamboo' (Bambusa vulgaris) was the species mostly used in processing (92\%), followed by yellow bamboo (Bambusa vulgaris vitatta) (5\%) and a mediumsized bamboo (species unidentified) (3\%). Characteristics that encouraged the processing of certain species above others included hardiness (42\%), higher demand (40\%) and increased resistance to rot and insects (18\%).

According to processors, factors determining quality include maturity $(68 \%)$, size and diameter $(22 \%)$, colour $(8 \%)$ and length or height (3\%).

Most furniture (chairs, beds, cupboards and tables) are made from large green Indian bamboo, whereas cups are mostly made from medium-sized bamboos (Table 21). Some clients include bricklayers who use the poles as measures and for scaffolding.

\section{Processing wastes and management}

Wastes generated during bamboo processing include unused small bamboo (58\%), peelings from the outer elum (the stem) (34\%) and shards of split bamboo (8\%). These wastes are usually thrown away $(61 \%)$ or used used for fuelwood (39\%).

\section{Market for processed products}

Most processors (63\%) graded their products prior to sale, while the remaining small group did not practice 
Table 17. Income generation sources for bamboo processors

\begin{tabular}{llllcrrr}
\hline Major occupation & N & Minimum & Maximum & Mean & Sum & $\begin{array}{c}\text { Std } \\
\text { deviation } \pm\end{array}$ & $\begin{array}{r}\text { Percentage of } \\
\text { respondents }\end{array}$ \\
\hline Craftsperson & 34 & 10000 & 650001 & 141985.32 & 4827501 & 158.632 & 92 \\
Farming & 4 & 50000 & 150000 & 100000.00 & 400000 & 40.824 & 8 \\
Total & 38 & 10000 & 650001 & 137565.82 & 5227501 & 150.829 & 100 \\
\hline
\end{tabular}

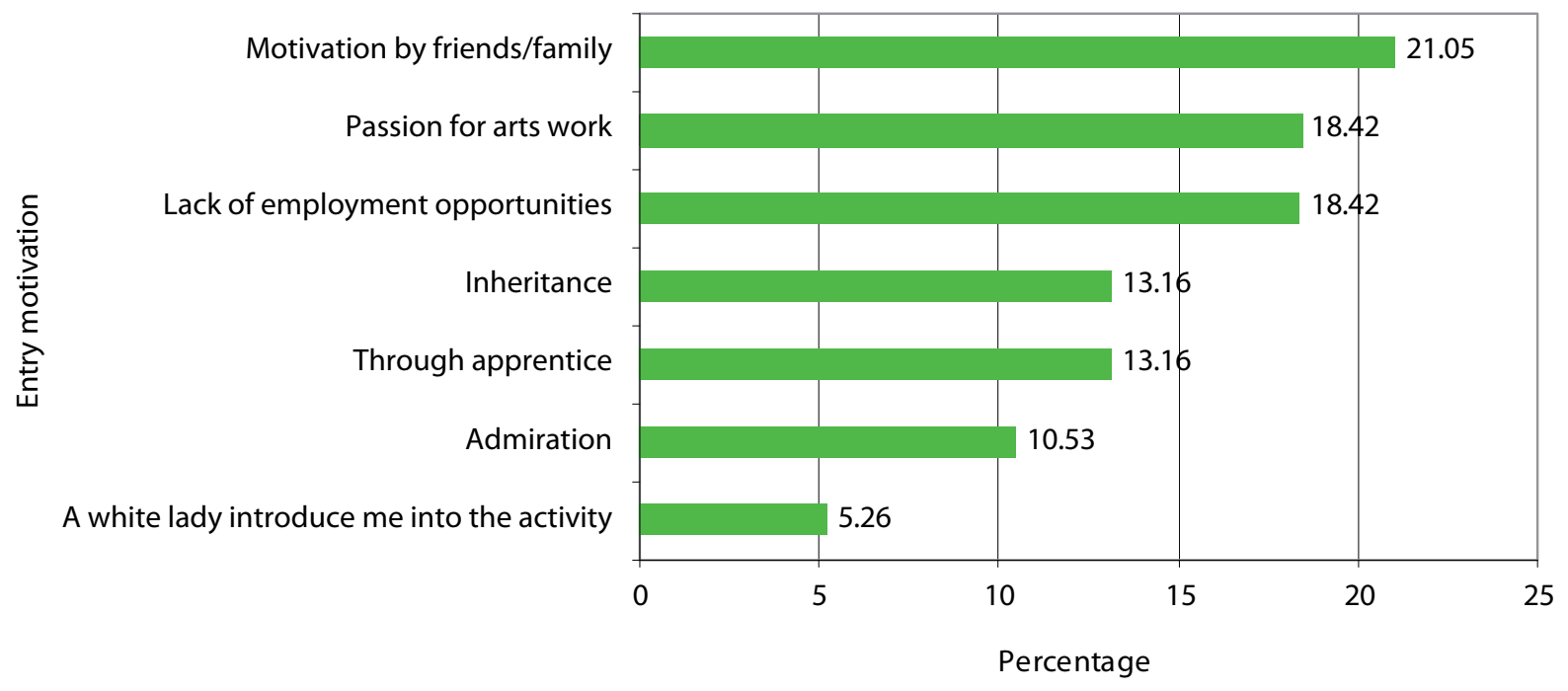

Figure 35. Motivation to process bamboo

this marketing strategy. Processed products were largely sold along roadsides $(82 \%)$, in workshops $(10 \%)$, urban markets $(5 \%)$ and in local markets (3\%). In local markets, bamboo products were purchased mainly by passers-by, known as 'tourists' (meaning they are not local) $(96.36 \%)$, with a small proportion purchased by wholesalers (3.3\%). Prices are commonly set by the processors themselves, with nine factors determining price setting, predominantly the quantity and quality of bamboo, materials used and labour time employed (29\%) (Table 22).

Apart from the women present in the processors' household, only $8 \%$ of processors employed other women to assist them in their enterprises; $32 \%$ of processors' children also assisted in cleaning and varnishing activities.

\section{Contribution of bamboo to processors' livelihoods}

Processors were found to have up to five sources of revenue, including bamboo processing. However, bamboo processing is a specialised and primary activity for the majority of processors, contributing to about $90 \%$ to the household income, with farming in a distant second position (Table 23). This may be linked to the fact that $31 \%$ of processors are based in urban areas, close to markets, where farming is not a primary activity.

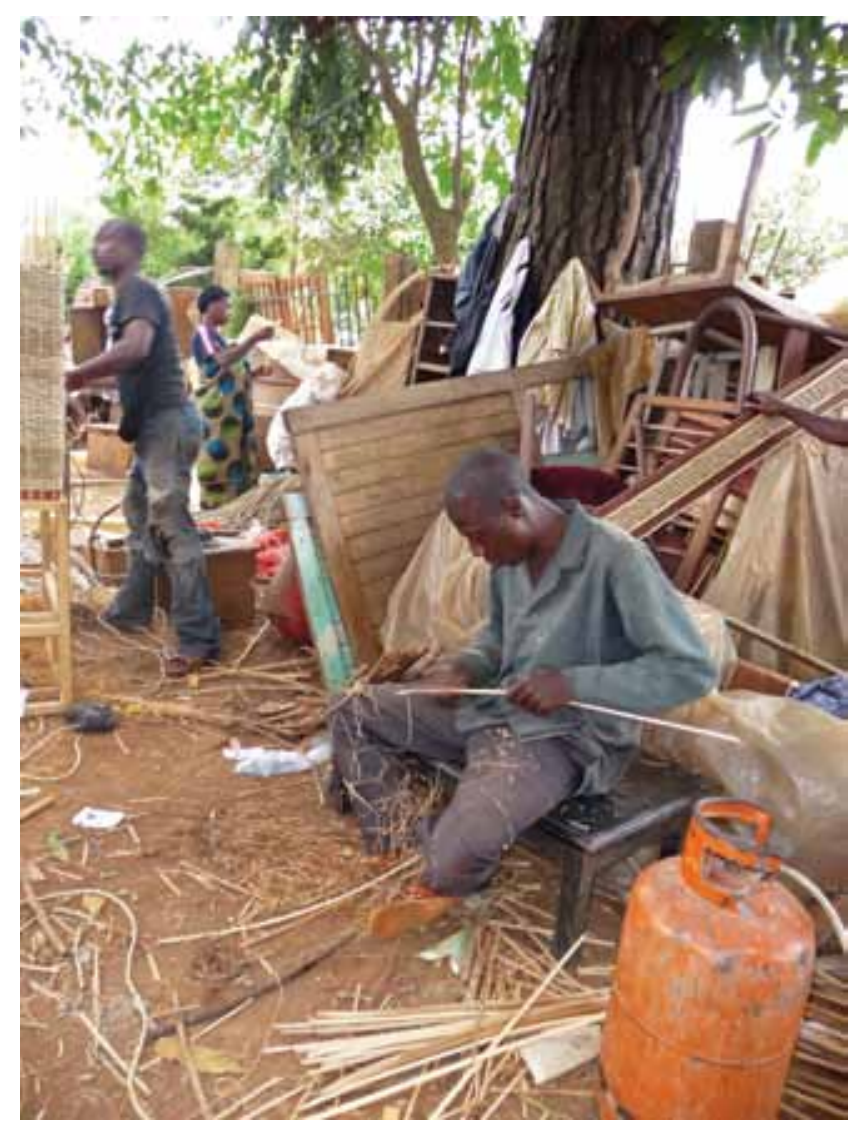

Figure 36. Bamboo and rattan processor craftsmen, Yaoundé 
Table 18. Processors' associations

\begin{tabular}{lc}
\hline Name of association & $\begin{array}{c}\text { Percentage of respondents belonging to an } \\
\text { association }\end{array}$ \\
\hline APVE (Association de la Protection et de la Valorisation) & 8 \\
APVF (Association de Protection et de Valorisation Forest) & 8 \\
Cercle des Jeunes de Zamakoe & 25 \\
ASVAMF (Association des Vanniers du Mfoundi) & 25 \\
ASAPROF (Association des Artisans des Produits Forestier) & 8 \\
Prescraft Bafut & 17 \\
Association of Bamboo and Rattan & 8 \\
Total & 100 \\
\hline
\end{tabular}

Table 19. Objectives of processors associations

\begin{tabular}{lcc}
\hline Objectives & Frequency mentioned & Percentage of respondents \\
\hline Valorise the activity & 5 & 42 \\
Promote craft/art work & 2 & 17 \\
Gain support from government and international organisations & 1 & 8 \\
Improve upon the standard of living of members & 1 & 8 \\
Sensitise actors on the importance of NTFP and valorise these & 1 & 8 \\
Work as a group to contribute to development & 1 & 8 \\
Opening cooperatives and product exhibition centres/showrooms & 1 & 8 \\
Total & 12 & 100 \\
\hline
\end{tabular}

Table 20. Derived/expected benefit from associations

\begin{tabular}{lcc}
\hline Derived/expected benefits & Frequency mentioned & Percentage of respondents \\
Exchange of ideas and work experience during seminars & 6 & 50 \\
Improve living standard & 2 & 17 \\
Creation of groups to concentrate/support efforts & 2 & 17 \\
Expect assistance from government or NGOs & 1 & 8 \\
Bulk buying of raw materials and collective work & 1 & 8 \\
Total & 12 & 100 \\
\hline
\end{tabular}

The majority of (65\%) of processors' annual income originates from manufacturing large household furniture, such as chairs, tables and cupboards. Smaller items such as flower pots, whistles and small sticks for grilled meat, known as 'soya sticks', contributed the remainder of a small proportion of total household income (Table 24).

\section{Processors' household expenditures}

Overall, bamboo processors' expenses are a combination of inputs and household needs. Raw materials are the largest proportion of expenses, followed by household needs, labour, miscellaneous items and equipment (Table 25).

A further breakdown of raw materials expenses shows that most processors spent their money procuring bamboo, followed by materials such as plywood and nails, glue and varnish. The remaining expenses were incurred on items such as gas and petrol thinners (Table 26).

Apprenticeship was common among processors and formed the main source of expenditure on labour. This is in contrast to the rattan sector where parents usually pay the artisans to train the apprentice (Sunderland 2001). The average annual expenditure on labour was $161368 \mathrm{CFAF}(\mathrm{SD}=269005 \mathrm{CFAF})$ with a range from zero to a maximum of $1080000 \mathrm{CFAF}$.

Generally, the equipment used by processors, similar to that used by collectors, is rudimentary; commonly available crafts tools include rechargeable sprayers, brushes, wooden benches/tables and knives. The most expensive equipment is varnish sprayers (Table 27). 
Table 21. Bamboo products and species

\begin{tabular}{|c|c|c|c|c|c|}
\hline \multirow{2}{*}{$\begin{array}{l}\text { Bamboo } \\
\text { products }\end{array}$} & \multicolumn{3}{|c|}{ Bamboo species used (1) } & \multirow[b]{2}{*}{ Total } & \multirow[b]{2}{*}{ Percentage of respondents } \\
\hline & $\begin{array}{l}\text { Large green Indian } \\
\text { (B. vulgaris) }\end{array}$ & $\begin{array}{l}\text { Medium size } \\
\text { (Species?) }\end{array}$ & $\begin{array}{l}\text { Yellow bamboo } \\
\text { (B. vulgaris) }\end{array}$ & & \\
\hline Chairs & 10 & & & 10 & 26 \\
\hline Beds & 4 & 1 & & 5 & 13 \\
\hline Cupboards & 3 & & 1 & 4 & 11 \\
\hline Tables & 15 & 2 & & 17 & 45 \\
\hline Cups & & 1 & & 1 & 3 \\
\hline Soya sticks & 1 & & & 1 & 3 \\
\hline Total & 33 & 4 & 1 & 38 & 100 \\
\hline$\%$ & 87 & 11 & 3 & 100 & 100 \\
\hline
\end{tabular}

Table 22. Price determinants for processed bamboo

\begin{tabular}{lcc}
\hline Factors & Frequency mentioned by respondents & Percentage of respondents \\
\hline Quantity of material used & 27 & 71 \\
Quality of material & 9 & 24 \\
Size & 6 & 16 \\
Beauty & 28 & 74 \\
Market demand & 7 & 18 \\
Labour (time) & 11 & 29 \\
Type of product & 3 & 8 \\
Cost of raw materials & 23 & 61 \\
Labour (time) & 11 & 29 \\
\hline
\end{tabular}

Table 23. Processors' annual sources of household income

\begin{tabular}{lcrrrrr}
\hline Source of household revenue & $\begin{array}{c}\text { Minimum } \\
\text { (CFAF) }\end{array}$ & $\begin{array}{c}\text { Maximum } \\
\text { (CFAF) }\end{array}$ & $\begin{array}{c}\text { Sum } \\
\text { (CFAF) }\end{array}$ & $\begin{array}{c}\text { Mean } \\
\text { (CFAF) }\end{array}$ & $\begin{array}{c}\text { Std deviation } \\
\pm \\
\text { (CFAF) }\end{array}$ & $\begin{array}{c}\text { Percentage of } \\
\text { respondents }\end{array}$ \\
\hline Bamboo processing & 26000 & 2600000 & 67694900 & 445361 & 412501 & 89 \\
Farming & 12000 & 300000 & 5550000 & 146052 & 73189 & 7 \\
Remittances & 60000 & 300000 & 760000 & 190000 & 106771 & 1 \\
Other trade & 20000 & 300000 & 735000 & 91875 & 90748 & 1 \\
Labourer & 20000 & 200000 & 565000 & 70625 & 57410, & 0.7 \\
Summary & 12000 & 2600000 & 75304900 & 358595 & 380216 & 100 \\
\hline
\end{tabular}

Table 24. Income from different bamboo products

\begin{tabular}{lrrrrrrr}
\hline Source of revenue & $\mathbf{N}$ & $\begin{array}{c}\text { Minimum } \\
\text { (CFAF) }\end{array}$ & $\begin{array}{c}\text { Maximum } \\
\text { (CFAF) }\end{array}$ & $\begin{array}{c}\text { Sum } \\
\text { (CFAF) }\end{array}$ & $\begin{array}{c}\text { Mean } \\
\text { (CFAF) }\end{array}$ & $\begin{array}{c}\text { Std } \\
\text { (CFAF) }\end{array}$ & $\begin{array}{c}\text { Percentage of } \\
\text { respondents }\end{array}$ \\
\hline Chairs & 23 & 120000 & 2500000 & 17410800 & 756991 & 548039 & 26 \\
Tables & 29 & 200000 & 1500000 & 15227300 & 525079 & 244392 & 22 \\
Cupboards & 17 & 110000 & 2600000 & 12634300 & 743194 & 640755 & 18 \\
Beds & 26 & 72500 & 972000 & 11141400 & 428515 & 293949 & 16 \\
Cups & 17 & 26000 & 629500 & 3427500 & 201618 & 149049 & 5 \\
Door blinds & 11 & 120000 & 710000 & 2954600 & 268600 & 196671 & 4 \\
Whistles & 9 & 50000 & 299000 & 1300000 & 144444 & 91948 & 2 \\
Wind charm & 5 & 80000 & 480000 & 1240000 & 248000 & 163195 & 2 \\
Flower pots & 7 & 45000 & 255000 & 1208000 & 172571 & 84774 & 2 \\
Soya sticks & 8 & 32000 & 520000 & 1151000 & 143875 & 160497 & 2 \\
Summary & 152 & 26000 & 2600000 & 67694900 & 445361 & 412501 & 100 \\
\hline
\end{tabular}


Table 25. Processors' expenditures

\begin{tabular}{lcccccc}
\hline Sources of expenditure & $\begin{array}{c}\text { Minimum } \\
\text { (CFAF) }\end{array}$ & $\begin{array}{c}\text { Maximum } \\
\text { (CFAF) }\end{array}$ & $\begin{array}{c}\text { Sum } \\
\text { (CFAF) }\end{array}$ & $\begin{array}{c}\text { Mean } \\
\text { (CFAF) }\end{array}$ & $\begin{array}{c}\text { Std } \\
\text { (CFAF) }\end{array}$ & $\begin{array}{c}\text { Percentage of } \\
\text { respondents }\end{array}$ \\
\hline Raw materials & 0 & 558000 & 24732060 & 72316 & 98069 & 47 \\
Household expenses & 0 & 580000 & 17956000 & 94505 & 117280 & 34 \\
Labour & 0 & 1080000 & 6132000 & 161368 & 269005 & 12 \\
Miscellaneous & 3000 & 100000 & 2538500 & 22268 & 16159 & 5 \\
Equipment & 500 & 34000 & 1294600 & 8517 & 9880 & 2 \\
Total & 0 & 1080000 & 52653160 & 62982 & 108485 & 100 \\
\hline
\end{tabular}

Table 26. Processors raw material costs

\begin{tabular}{lrrrrrrr}
\hline Source of expense & $\mathbf{N}$ & $\begin{array}{c}\text { Minimum } \\
\text { (CFAF) }\end{array}$ & $\begin{array}{c}\text { Maximum } \\
\text { (CFAF) }\end{array}$ & $\begin{array}{c}\text { Sum } \\
\text { (CFAF) }\end{array}$ & $\begin{array}{c}\text { Mean } \\
\text { (CFAF) }\end{array}$ & $\begin{array}{c}\text { Std } \\
\text { (CFAF) }\end{array}$ & $\begin{array}{c}\text { Percentage of } \\
\text { respondents }\end{array}$ \\
Bamboo & 38 & 86400 & 558000 & 11119980 & 292631 & 116426 & 45 \\
Plywood & 38 & 39600 & 192000 & 3718800 & 97863 & 4274 & 15 \\
Nails & 38 & 12000 & 206400 & 3669600 & 96568 & 5460 & 15 \\
Glue & 38 & 24000 & 258000 & 2630400 & 69221 & 39899 & 11 \\
Varnish & 38 & 8400 & 180000 & 1724700 & 45387 & 35282 & 7 \\
Others & 38 & 10000 & 72000 & 1092000 & 28737 & 17413 & 4 \\
Gas & 38 & 0 & 30600 & 347775 & 9152 & 7082 & 1 \\
Petrol & 38 & 690 & 15600 & 241305 & 6350 & 3858 & 1 \\
Thinner & 38 & 1200 & 14400 & 187500 & 4934 & 2842 & 1 \\
Total & 342 & 0 & 558000 & 24732060 & 72315 & 9806 & 100 \\
\hline
\end{tabular}

Table 27. Processors' equipment costs

\begin{tabular}{lrrrrrrr}
\hline Source of expense & $\mathbf{N}$ & $\begin{array}{c}\text { Minimum } \\
\text { (CFAF) }\end{array}$ & $\begin{array}{c}\text { Maximum } \\
\text { (CFAF) }\end{array}$ & $\begin{array}{c}\text { Sum } \\
\text { (CFAF) }\end{array}$ & $\begin{array}{c}\text { Mean } \\
\text { (CFAF) }\end{array}$ & $\begin{array}{c}\text { Std } \\
\text { (CFAF) }\end{array}$ & Percentage of respondents \\
\hline $\begin{array}{l}\text { Equipment (sprayer } \\
\text { battery, etc) }\end{array}$ & 38 & 10000 & 34000 & 910000 & 23947 & 7377 & 70 \\
$\begin{array}{l}\text { Brushes } \\
\text { Benches/tables }\end{array}$ & 38 & 1200 & 12000 & 183600 & 4832 & 3142 & 14 \\
Knives & 38 & 500 & 6000 & 103900 & 2734 & 1453 & 8 \\
Total & 38 & 500 & 8000 & 97100 & 2555 & 1611 & 7 \\
\hline
\end{tabular}

Table 28. Processors' miscellaneous costs

\begin{tabular}{lrrrrrrr}
\hline Source of expense & N & $\begin{array}{c}\text { Minimum } \\
\text { (CFAF) }\end{array}$ & $\begin{array}{c}\text { Maximum } \\
\text { (CFAF) }\end{array}$ & $\begin{array}{c}\text { Sum } \\
\text { (CFAF) }\end{array}$ & $\begin{array}{c}\text { Mean } \\
\text { (CFAF) }\end{array}$ & $\begin{array}{c}\text { Std } \\
\text { (CFAF) }\end{array}$ & $\begin{array}{c}\text { \% in sum } \\
\text { Transportation (year) }\end{array}$ \\
Land/workshop rent (year) & 38 & 10000 & 55000 & 1113000 & 29289 & 12595 & 44 \\
Overheads & 38 & 5000 & 60000 & 750500 & 19750 & 11203 & 30 \\
Taxes & 8 & 10000 & 100000 & 304000 & 38000 & 30701 & 12 \\
Others fees/levies paid & 12 & 3000 & 80000 & 217000 & 18083 & 20318 & 9 \\
Interest on loans & 13 & 3000 & 13000 & 105000 & 8077 & 2957 & 4 \\
Summary & 5 & 5000 & 14000 & 49000 & 9800 & 3492 & 2 \\
\hline
\end{tabular}


Annual miscellaneous expenses for processors included transportation, land and/or workshop rental, overheads, fees and interest on loans. Among these, the highest proportion of expenses (43\%) involved transportation, followed by renting land/workshop space (Table 28). Taxes are often a contentious subject for small enterprises, particularly due to the sector's informality and problems with corruption. Inconsistencies arise where while nearby markets or sales points may be formal, regulated and taxed, some enterprises and products are not. For example, some craftsmen in Tunnel Mboppi, Douala, do not pay taxes but those selling at the Marché des Fleurs are regulated and pay fees.

\section{Household expenses}

The main household expenses named by processors were all basic needs predominantly food $(60 \%)$, house rent (21\%), followed by children's school fees, clothing and medical treatment (Table 29).

\section{Bamboo Traders}

\section{Socio-demographic profile of traders}

This study was not intended as a comprehensive assessment of bamboo traders in Cameroon. As detailed in the Methodology section, a random sample of traders was selected in locations across Cameroon that were assessed to be major trading and consumption areas. A total of 31 traders were interviewed, with the majority (35\% each) located in the West and Southwest regions. Littoral, Centre and Northwest accounted for only $13 \%$, $10 \%$ and $6 \%$ of the traders interviewed respectively. The average trader's age is 36 years, ranging from 22-63 years. Only $7 \%$ of traders are women. Three per cent had no formal schooling, $45 \%$ had primary schooling, $26 \%$ had secondary, and $10 \%$ each had obtained middle school and university studies and $6 \%$ polytechnicl training college. The majority $(84 \%)$ were natives of the area where they traded, while $16 \%$ were migrants. Most $(77 \%)$ were married and nearly a quarter $(23 \%)$ single. A trader's household size varied from one to 14 people with average of five ( $\mathrm{SD}= \pm 3$ persons).

\section{Major occupation}

Bamboo trading was the major occupation for $32 \%$ of traders, closely followed by handicraft and farming (Figure 37). This indicates a lower level of professionalisation and specialisation, compared to craftsperson processors who focus on bamboo and rattan. It is, however, a similar proportion to collectors, showing how these two groups depend on multiple sources of income for their total annual household revenues.

Agriculture was a minor activity for $55 \%$ of the bamboo traders, (which is unsurprising given that $90 \%$ of traders are located in urban areas), followed by handicraft $(19 \%)$ and unskilled labour (16\%) (Figure 38).

\section{Level of traders' organisation}

Similar to craftpeople, the majority of traders work individually, with nearly one-third (32\%) belonging to an association. The types of associations ranged from youth groups to specialised product groups and cooperatives (Table 30).

The associations' objectives ranged from ensuring collective work and improving the bamboo sector to assisting members in seeking national and international aid (Table 31).

The perceived benefits of joining an association include an expectation of improving living standards (40\%), the possibility to access support through an association $(30 \%)$ and free training on better production techniques (30\%).

\section{Products traded and markets}

Bamboo traders include middlemen (17\%), wholesalers $(5 \%)$ retailers of unprocessed bamboo $(78 \%)$, and retailers $(92 \%)$ or wholesalers (8\%) of processed products. Most traders sell unprocessed bamboo poles (56\%), 28\% sell processed chairs and $11 \%$ benches (Table 32).

Six major product types were sold, predominantly chairs (45\%), bamboo poles used as television masts and electricity posts (32\%), bamboo benches (10\%), cups $(7 \%)$, flutes and beds (3\% each). The informality and low level of marketing is evident in the large proportion who sell from roadsides (54\%), followed by selling from home (32\%) and markets, which form a very small proportion (3\%) as do showrooms or stores. This marketing strategy both creates and reinforces the low quality product image of bamboo artefacts and at the same time, makes products widely and openly available, particularly for poorer households (Table 33).

On average, the majority (77\%) of traders' clients are local customers while the remainder originate from across the country. Prices are often not fixed and not advertised, particularly at the roadside selling points, where prices are largely determined $(48 \%)$ at the time of sale. Traders reported that the sale price they offered depended on the type of buyer and their perception of the price they could or would be willing to pay. Prices are commonly negotiated, as is common for many other crafts, agricultural and NTFP products in Cameroon. A small proportion (16\%) of traders based the selling price on the type or model of products to be sold, $13 \%$ according to going market price and $23 \%$ were not clear, stating that selling prices fluctuate and are not 'exact'. 
Table 29. Processors' household expenses

\begin{tabular}{lrrrrrrr}
\hline Source of expense & $\mathbf{N}$ & $\begin{array}{c}\text { Minimum } \\
\text { (CFAF) }\end{array}$ & $\begin{array}{c}\text { Maximum } \\
\text { (CFAF) }\end{array}$ & $\begin{array}{c}\text { Sum } \\
\text { (CFAF) }\end{array}$ & $\begin{array}{c}\text { Mean } \\
\text { (CFAF) }\end{array}$ & $\begin{array}{c}\text { Std } \\
\text { (CFAF) }\end{array}$ & $\begin{array}{c}\text { \% in sum } \\
\text { Food }\end{array}$ \\
Household rent & 38 & 128000 & 580000 & 10710000 & 281842 & 104722 & 60 \\
School fees & 38 & 10000 & 480000 & 3762000 & 99000 & 92618 & 21 \\
Clothing & 38 & 0 & 180000 & 1546000 & 40684 & 36725 & 9 \\
Medicals & 38 & 10000 & 80000 & 1115000 & 29342 & 16965 & 6 \\
Summary & 38 & 3000 & 65000 & 823000 & 21658 & 15104 & 4 \\
\hline
\end{tabular}

Table 30. Traders associations in Cameroon

\begin{tabular}{lc}
\hline Name of association & Percentage of respondents \\
\hline Association of Bamboo and Rattan Collectors & 30 \\
Cercles des Jeunes de Zamakoe & 10 \\
APVF (Association de la Protection et de la Valorisation) & 10 \\
ASVAM (Association des Vanniers du Mfoundi) & 20 \\
Bamenda Handicraft Cooperative & 10 \\
Prescraft Bafut & 10 \\
Association des artisans des produits forestiers & 10 \\
Total & 100 \\
\hline
\end{tabular}

Table 31. Objectives of traders associations

\begin{tabular}{lc}
\hline Objectives of associations & Percentage of respondents \\
\hline Collective work & 10 \\
Sensitisation of the youths and modernisation of the handicraft & 10 \\
Improve the bamboo sector & 30 \\
To join bamboo harvesters together & 20 \\
Improve members' standard of living & 10 \\
Assist in the sales of the members' products & 10 \\
Assist members in seeking national and international aid & 10 \\
Total & 100
\end{tabular}

Table 32. Proportion of traders and bamboo products

\begin{tabular}{|c|c|c|c|c|c|c|}
\hline \multirow{2}{*}{ Category of trader } & \multicolumn{4}{|c|}{ Bamboo products } & \multirow{2}{*}{ Total } & \multirow{2}{*}{$\%$} \\
\hline & Bamboo bench & Flutes & Chairs & Bamboo sticks & & \\
\hline Middleman & & & 2 & 1 & 3 & 17 \\
\hline Wholesaler & & & 1 & & 1 & 6 \\
\hline Retailer & 2 & 1 & 2 & 9 & 14 & 78 \\
\hline Total & 2 & 1 & 5 & 10 & 18 & 100 \\
\hline$\%$ & 11 & 6 & 28 & 56 & 100 & \\
\hline
\end{tabular}




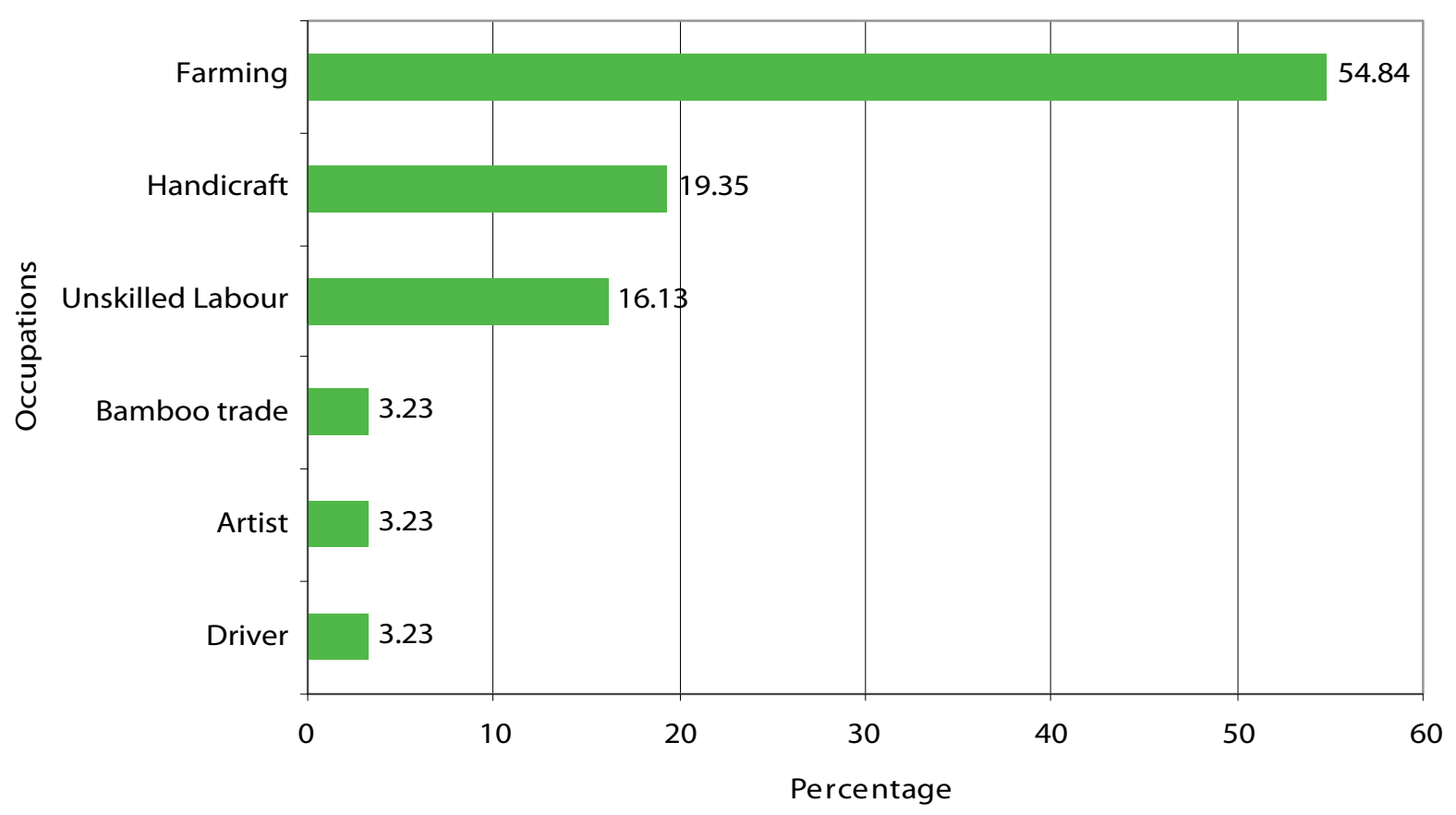

Figure 37. Bamboo traders' major income sources

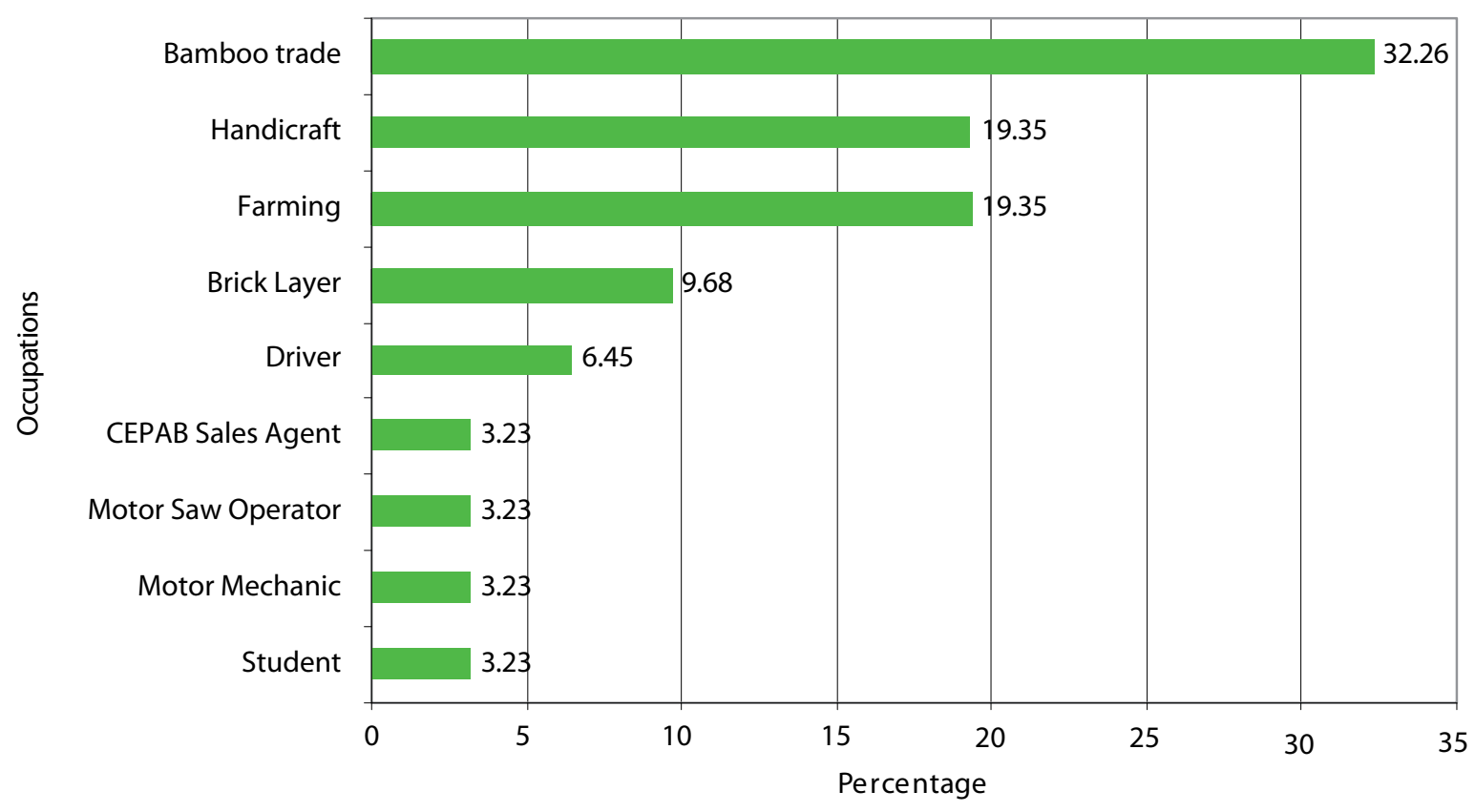

Figure 38. Minor income sources for bamboo traders 
Table 33. Bamboo products and markets

\begin{tabular}{|c|c|c|c|c|c|c|}
\hline \multirow{2}{*}{ Products } & \multicolumn{4}{|c|}{ Market type } & \multirow{2}{*}{ Total } & \multirow{2}{*}{ Percentage products found in markets } \\
\hline & Roadside & Market & Home & Store & & \\
\hline Bamboo bench & 1 & 2 & & & 3 & 10 \\
\hline Cups & 1 & 1 & & & 2 & 6 \\
\hline Flutes & & & & 1 & 1 & 3 \\
\hline Beds & & & 1 & & 1 & 3 \\
\hline Chairs & 13 & & 1 & & 14 & 45 \\
\hline Bamboo sticks & 2 & & 8 & & 10 & 32 \\
\hline Total & 17 & 3 & 10 & 1 & 31 & 100 \\
\hline$\%$ & 55 & 10 & 32 & 3 & 100 & \\
\hline
\end{tabular}

Table 34. Product price determinants

\begin{tabular}{lrr}
\hline Determinant & Frequency & Percentage \\
\hline Demand & 12 & 39 \\
Quantity of raw material used & 6 & 19 \\
Quality of products & 5 & 16 \\
Beauty of product & 4 & 13 \\
Time spent & 4 & 13 \\
Total & 31 & 100 \\
\hline
\end{tabular}

Table 35. Traders' preferred species and reasons

\begin{tabular}{|c|c|c|c|c|c|c|}
\hline \multirow{2}{*}{ Species } & \multicolumn{4}{|c|}{ Reason } & \multirow{2}{*}{ Total } & \multirow{2}{*}{$\%$} \\
\hline & Demand & Resistance & Easy to use & Availability & & \\
\hline Large green bamboo & 13 & 4 & 3 & 5 & 25 & 81 \\
\hline Medium-sized green bamboo & 2 & & & & 2 & 6 \\
\hline Yellow bamboo & 1 & 3 & & & 4 & 13 \\
\hline Total & 16 & 7 & 3 & 5 & 31 & 100 \\
\hline$\%$ & 52 & 23 & 10 & 16 & 100 & \\
\hline
\end{tabular}

Table 36. Trader's income sources

\begin{tabular}{lrrrrrrr}
\hline Source of revenue & N & $\begin{array}{c}\text { Minimum } \\
\text { (CFAF) }\end{array}$ & \multicolumn{1}{c}{$\begin{array}{c}\text { Maximum } \\
\text { (CFAF) }\end{array}$} & \multicolumn{1}{c}{$\begin{array}{c}\text { Mean } \\
\text { (CFAF) }\end{array}$} & \multicolumn{1}{c}{$\begin{array}{c}\text { Std } \\
\text { (CFAF) }\end{array}$} & $\begin{array}{c}\text { Sum } \\
\text { (CFAF) }\end{array}$ & $\begin{array}{c}\text { Percentage of } \\
\text { respondents }\end{array}$ \\
\hline Bamboo and products & 31 & 330000 & 1240000 & 709032 & 247256 & 21980000 & 75 \\
Farm & 31 & 20000 & 557000 & 170687 & 155868 & 5291300 & 18 \\
Labourer & 7 & 34000 & 130000 & 83571 & 34563 & 585000 & 2 \\
Livestock & 5 & 40000 & 200000 & 94000 & 6220 & 470000 & 2 \\
Trade other goods & 8 & 20000 & 100000 & 58125 & 29270 & 465000 & 2 \\
Remittances & 4 & 10000 & 80000 & 53500 & 30914 & 214000 & 0.73 \\
Fishing & 3 & 12000 & 140000 & 57333 & 71703 & 172000 & 0.59 \\
Others & 3 & 5000 & 17000 & 9667 & 6429 & 29000 & 0.10 \\
Summary & 31 & 5000 & 124000 & 317460 & 3308723 & 29206300 & 100 \\
\hline
\end{tabular}


Table 37. Expenses incurred by bamboo traders

\begin{tabular}{lrrrrrr}
\hline Source of expense & N & $\begin{array}{c}\text { Minimum } \\
\text { (CFAF) }\end{array}$ & $\begin{array}{c}\text { Maximum } \\
\text { (CFAF) }\end{array}$ & $\begin{array}{c}\text { Mean } \\
\text { (CFAF) }\end{array}$ & \multicolumn{1}{c}{$\begin{array}{c}\text { Sum } \\
\text { (CFAF) }\end{array}$} & $\begin{array}{c}\text { Percentage total } \\
\text { expenses }\end{array}$ \\
\hline Store/stall rent & 31 & 50000 & 960000 & 466129 & 14450000 & 53 \\
Food & 30 & 19000 & 300000 & 153567 & 4607000 & 17 \\
Association dues & 31 & 10000 & 600000 & 72806 & 2257000 & 8 \\
House rent & 20 & 15000 & 150000 & 63400 & 1268000 & 5 \\
Transformation of goods & 31 & 5000 & 100000 & 4083 & 1266000 & 5 \\
Goods & 31 & 1750 & 150000 & 33621 & 1042250 & 4 \\
Clothing & 32 & 5000 & 98000 & 31000 & 992000 & 4 \\
Medical fees & 14 & 9000 & 100000 & 48500 & 679000 & 2 \\
School fees & 8 & 20000 & 130000 & 55375 & 443000 & 1 \\
Taxes/levies/market tolls & 9 & 4000 & 75000 & 30444 & 274000 & 1 \\
Summary & 31 & 1750 & 960000 & 115098 & 27278250 & 100 \\
\hline
\end{tabular}

Table 38. Uses of bamboo per region

\begin{tabular}{|c|c|c|c|c|c|}
\hline \multirow{2}{*}{ Uses of bamboo } & \multicolumn{3}{|c|}{ Responses per region* } & \multirow{2}{*}{ Total } & \multirow{2}{*}{$\begin{array}{l}\text { Percentage of } \\
\text { respondents }\end{array}$} \\
\hline & Littoral & Southwest & West & & \\
\hline Supports for agriculture & 4 & 7 & 6 & 17 & 22 \\
\hline TV aerial mast & 1 & 10 & & 11 & 15 \\
\hline Building decking & & 9 & 1 & 10 & 13 \\
\hline Fuelwood & 1 & 5 & 3 & 9 & 13 \\
\hline House roofing & 2 & & 6 & 8 & 10 \\
\hline Fencing & & 3 & 3 & 6 & 8 \\
\hline Electric posts & & 4 & & 4 & 5 \\
\hline Band & & & 3 & 3 & 4 \\
\hline Building houses & 2 & & 1 & 3 & 4 \\
\hline Furniture & 1 & & 1 & 2 & 3 \\
\hline Ladders & & 1 & 1 & 2 & 3 \\
\hline Bow and arrows & & 1 & & 1 & 1 \\
\hline Flutes & & & 1 & 1 & 1 \\
\hline Soya stick & & 1 & & 1 & 1 \\
\hline Total & 11 & 41 & 26 & 78 & 100 \\
\hline Percentage & 14 & 53 & 33 & 100 & \\
\hline
\end{tabular}

*Consumers only from Littoral, Southwest and West

\section{Price determinants of bamboo products}

Traders named five factors that determine product price, with demand (39\%) being the major consideration, followed by the quantity of raw material used (19\%) (Table 34).

\section{Trader perceptions of bamboo species}

Traders' preference for different bamboo species was clear (Table 35), with most favouring large green Indian Bamboo (81\%), followed by yellow bamboo (13\%) (both species of Bambusa vulgaris) and only a small percentage preferring medium-sized green bamboo (6\%). Interestingly, availability was not mentioned as a determinant of preference. The reasons for these preferences are based on demand (52\% of traders) and to a lesser extent the ease of using the raw material (10\%). Traders believe that bamboo quality is determined by maturity (68\%), size/diameter (19\%), height (10\%) and leaves (3\%).

\section{Contribution of bamboo to traders' livelihoods}

The bamboo trade constitutes a major source of annual revenue for traders with a mean of 709032 CFAF $(\mathrm{SD}=247256 \mathrm{CFAF})$ and a range from 330000 to 1 240000 CFAF. Trade in bamboo raw materials and/ or processed products constituted $75 \%$ of traders' incomes, followed by farming (18\%) and other income sources $(7 \%)$ (Table 36). 


\section{Traders' expenses}

Ten types of annual household expenses were identified (Table 37). The largest proportion of annual expenses is spent renting business premises $(53 \%)$ and on food $(17 \%)$.

\section{Consumers}

\section{Bamboo consumption, preference and suggestions}

A total of 41 consumers of bamboo were interviewed in the West (33\%), Southwest (53\%) and Littoral regions (14\%). Fourteen possible uses of bamboo were identified, with bamboo largely used in construction and tools in all regions, specifically as supports for agriculture, masts for television antennae, decking for houses, fuelwood, roofing and fences (Table 38).

In terms of quality, most consumers asserted that the majority of bamboo products were of high quality (51\%), with $22 \%$ indicating that they perceived bamboo products as being of average quality, $17 \%$ as of low quality, $7 \%$ as durable and $2 \%$ easily flammable, compared to other products of similar applications (Table 39). Although a comparison is made between different products and materials and prices, an important factor is that in Cameroon bamboo is substitutable for a number of materials, including wood, plastic, metal and other NTFPS such as rattan and palm fibres.

In terms of price, all consumers believe that bamboo products are cheaper compared with equivalent wood or plastic products, with $66 \%$ stating that bamboo products and tools are durable, solid and resistant to insects while $34 \%$ believe they are not durable, lasting only a few years. Nearly a quarter (24\%) of consumers stated that bamboo products were more attractive than comparable products of other materials, $73 \%$ stated they were not attractive enough and 3\% appreciated the lighter weight of bamboo compared to similar products made of other materials. Most bamboo consumers (90\%) feel that the amount they pay is proportional to product quality, while $10 \%$ believe the contrary.

Most consumers expressed interest in seeing a wider range of bamboo products on the market, with the major items of interest being large furniture and household construction and furnishing materials (Table 40).

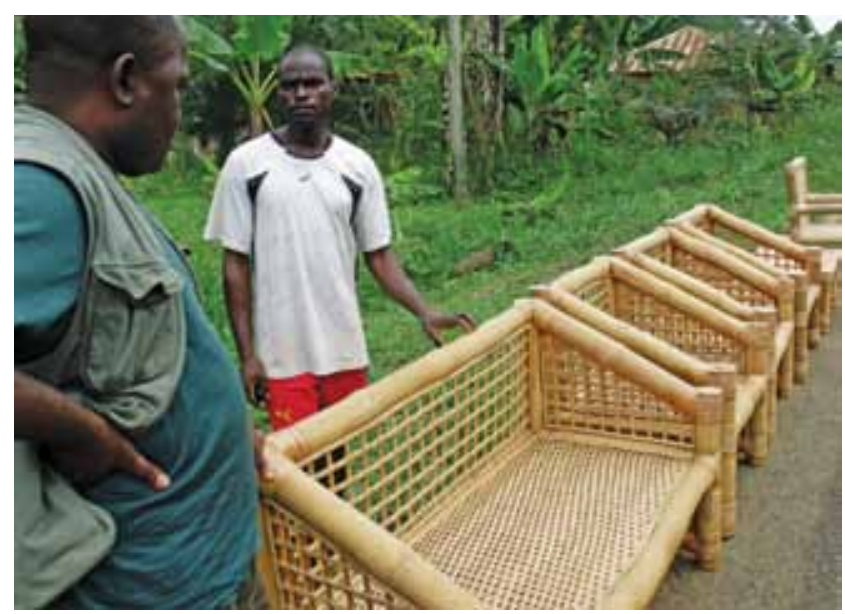

Figure 39. Roadside bamboo furniture marketing, near Mbalmayo

Table 39. Quality comparison of bamboo vs. other products

\begin{tabular}{lll}
\hline Quality standard & Frequency & Percentage \\
\hline Low quality & 7 & 17 \\
High quality & 21 & 51 \\
Average & 9 & 22 \\
Durable & 3 & 7 \\
Flammable & 1 & 2 \\
Total & 41 & 100 \\
\hline
\end{tabular}

Table 40. Consumer ranking of potentially interesting bamboo products

\begin{tabular}{lll}
\hline Item & Number & Yes (\%) \\
\hline Chairs & 41 & 37 \\
Tables & 41 & 32 \\
Cupboards & 41 & 29 \\
Beds & 41 & 20 \\
TV stands & 41 & 5 \\
Ceilings & 41 & 2 \\
Plates & 41 & 2 \\
Walking stick & 41 & 2 \\
Pipes for water & 41 & 2 \\
Spears & 41 & 2 \\
Total & 41 & 100 \\
\hline
\end{tabular}




\section{Development of the bamboo sector in Cameroon}

\section{Problems, constraints and opportunities in the bamboo sector}

Belcher (1998) and Ruiz-Pérez (1999) note that successful trade requires a minimum set of skills and assets, including business contacts and knowledge of the ways of doing business. Poor people typically do not have those skills and assets and so, when new commercial opportunities arise, they may be outcompeted by local 'elites', with more power and capital to invest, better connections, and better skills, or by competitors from other areas. Research in China shows differential benefits to different farmers and harvesters depending upon local conditions and their level of development. In the early stages of PCS development as opportunities in the bamboo sector increased and farmers intensified their management, better-off households gained the largest share of the increased earnings, and poorer households gained the least. As areas develop, middle income farmers tend to get proportionally more income from bamboo ( Ruiz-Pérez et al. 2009).

Whether the market is newly established or traditional, efforts to support trade need to understand the structure and function of the entire production to consumption system (Belcher 1998). The most effective interventions have been evaluated as those with a simultaneous impact on many similar firms, termed 'leverage'. Thus, policy-level interventions that encourage investment in processing and trade may be the most effective way to support raw material producers, as seen very clearly in the case of the China Bamboo sector ( Ruiz-Pérez et al. 2004), and given the current situation in Cameroon (Tieguhong and Ndoye 2004; Laird, McLain, and Wynberg 2009), is expected to be similar. The size and nature of the market are crucial factors to consider. Goods and services that are primarily exported outside the producing region tend to have significantly larger markets and can act as a powerful engine for economic growth, as in the case of bamboo production and processing in Anji County, China (Fu and Yang 2004, cited in (Belcher and Schreckenberg 2007) which may have similar repercussions for the trade in Cameroon.

Apart from the general concerns raised, specific and related concerns and opportunities were reiterated by each group of actors (collectors, processors, traders) as well as ways forward. Consumers also suggested some possible ways forward that can enhance the development of Cameroon's bamboo sector.

\section{Constraints and opportunities in harvesting}

Collectors cited six major problems faced (Figure 40)

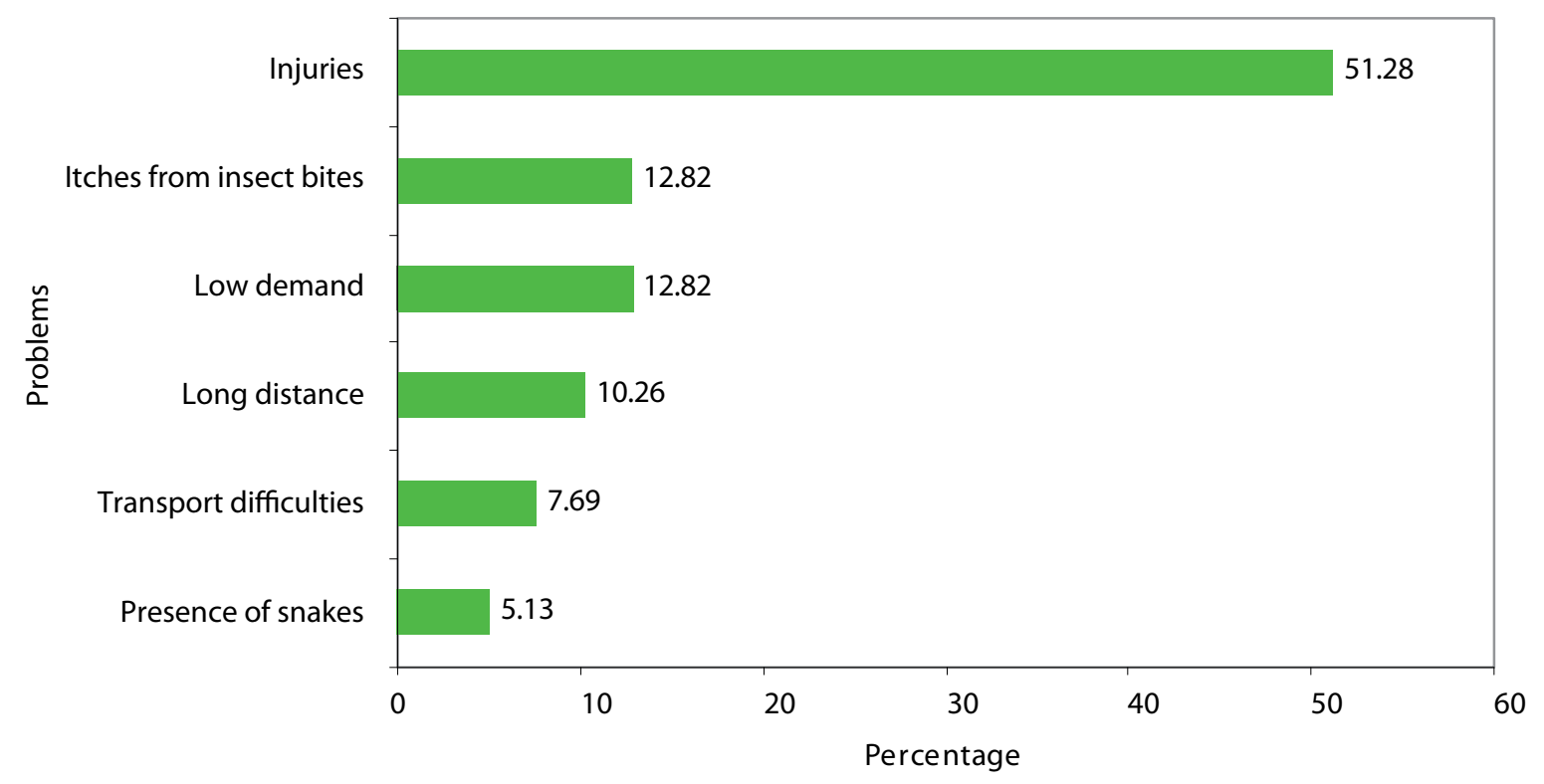

Figure 40. Problems faced by bamboo harvesters 
Table 41. Problems faced by bamboo processors

\begin{tabular}{lcc}
\hline Problems & Frequency & Percentage \\
\hline Low prices & 18 & 47 \\
Low demand & 13 & 34 \\
Unorganised market & 12 & 32 \\
Very low profits & 12 & 32 \\
Jealousy among actors & 7 & 18 \\
Lack of capital & 5 & 13 \\
Transportation & 5 & 13 \\
Consumers ignorance of bamboo products & 4 & 11 \\
\hline
\end{tabular}

Table 42. Problems and practical solutions

\begin{tabular}{|c|c|c|c|c|c|c|c|}
\hline \multirow[b]{2}{*}{ Problem } & \multicolumn{5}{|c|}{ Solution } & \multirow[b]{2}{*}{ Total } & \multirow[b]{2}{*}{$\%$} \\
\hline & Chemicals disinfection & Use good saw & $\begin{array}{l}\text { Use } \\
\text { glue }\end{array}$ & Expose to sunlight & Use gloves & & \\
\hline $\begin{array}{l}\text { Infestation leading to easy } \\
\text { splitting }\end{array}$ & 21 & & 2 & & & 23 & 60 \\
\hline $\begin{array}{l}\text { Moulding of bamboo } \\
\text { during rainy season }\end{array}$ & & & & 4 & & 4 & 11 \\
\hline Injuries & 5 & & & & 3 & 8 & 21 \\
\hline Very hard to cut & & 3 & & & & 3 & 8 \\
\hline Total & 26 & 3 & 2 & 4 & 3 & 38 & 100 \\
\hline$\%$ & 68 & 8 & 5 & 11 & 8 & 100 & \\
\hline
\end{tabular}

while collecting bamboo, ranging from injuries $(51 \%)$ to threats from snakes $(5 \%)$. Bamboo appears to attract snakes and particularly the poisonous green mambas, which presents a problem during harvesting. Focus group discussions also indicated a lack of knowledge on diversification for construction and other uses, and a lack of knowledge on the appropriateness of different species for different uses.

Most of the collectors felt helpless about the daily problems they face, but some suggested three possible solutions including buying anti-venom (either traditional remedies or pharmaceutical drugs) and bite drugs (49\%); financial support (21\%); use of medicated soaps and the provision of trucks to ease transport difficulties (15\% each).

\section{Constraints and opportunities in processing}

Processors cited eight major problems for which they had no immediate solutions or means to resolve (Table 41). These include low demand for their products (34\%), leading to long product turnaround times and resulting in higher chance of insect damage to both raw and processed products, and also correlated to low prices (47\%), unorganised markets $(32 \%)$ and low profits (32\%)An interesting comparison can be made here with the rattan sector in Cameroon, where commissioned furniture products (produced on command for customers) constitute the majority of trade.
Problems with storage (insect damage and infestation, mainly by weevils and termites) were mentioned by processors, but also by collectors who store for longer periods, as well as retailers. Few or no effective pesticide products were on the market (depending on location, especially outside the cities of Douala and Yaoundé) for protection or treatment. Processors suggested various solutions, from only producing on demand, to searching for assistance to obtain capital and ways to ease transportation by acquiring vehicles. For insects, while some chemicals are on the market, good treatment is not always available and advice could be sought from experts.

Although these constraints were seen as are hard to manage, some processors identified ways to deal with them. Table 42 shows how problems of infestation and split are being dealt with using chemicals and glue. Problems related to moulding are dealt with by exposing products to sunlight, and injuries by using gloves and disinfecting the wounds. Very hard bamboo is cut with a saw instead of a cutlass.

\section{Constraints and opportunities in bamboo trading and marketing}

Major constraints on trade and marketing of bamboo products range from low demand to price fluctuations and rudimentary or bad quality working tools and substitution of inferior materials, or 'counterfeiting' (Figure 41). 


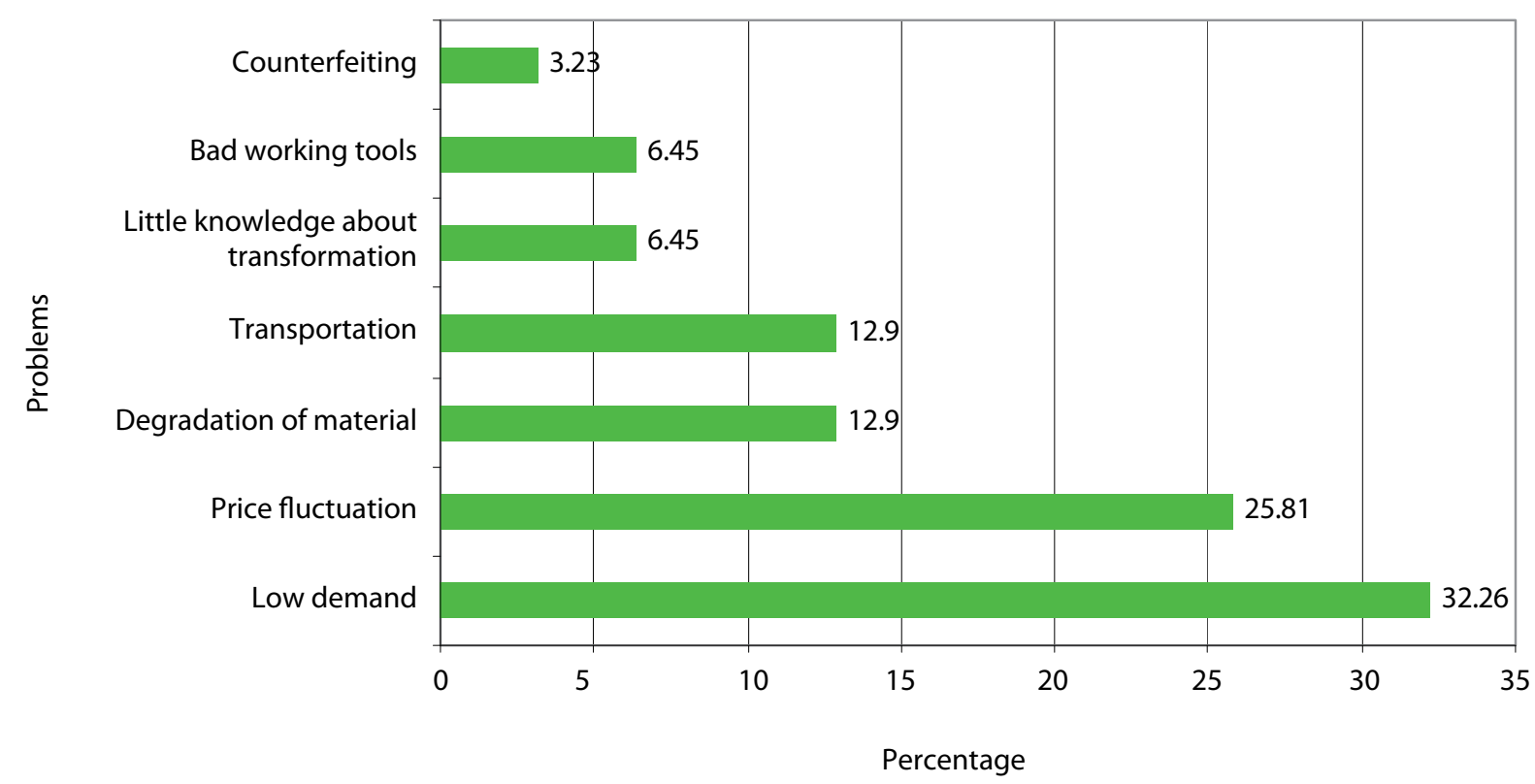

Figure 41. Constraints faced by traders

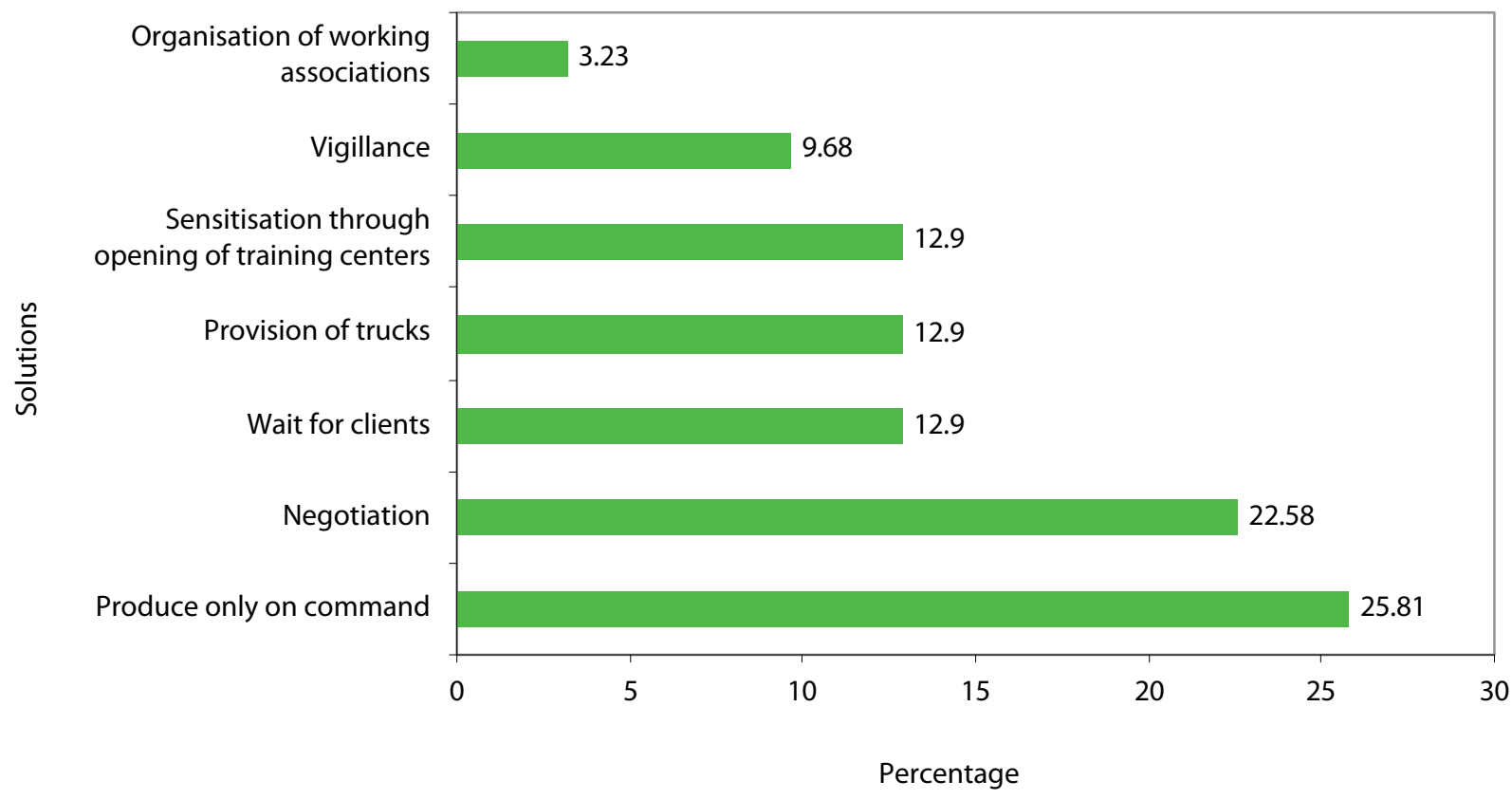

Figure 42. Solutions to problems faced by traders

During the field work, many actors also raised general opportunities for the sector, which are elaborated below and in Figure 42:

- Capacity building on technical skills, especially for processors but also in harvest and retail trade, due to the current low level of knowledge and skills.

- Combating infestation to produce marketable and durable products.

- Setting grading standards for products to ensure quality and attract potential buyers.

- Establish functional training centres or courses for craft artisans and processors.

- Exchange ideas through organisation of seminars.
- Subsidies or provision of start-up capital and reduction in taxes.

- Construction of showrooms to exhibit bamboo products.

- Strengthening the value chain, especially bamboo processing.

- Planting more bamboo to alleviate the reducing resource quantities, especially in urban areas like Yaoundé.

- Production only on demand.

- Organisation of associations.

- Vigilance to reduce issues such as theft, infestation and a term used to mean attending to customer requirements. 



\section{Policy and institutional framework for the bamboo sector}

\section{Policy environment}

Cameroon currently has no specific policy to promote the bamboo sector either at the local or national level. However, a policy appears to be emerging. A five-member official delegation from Cameroon, headed by the Secretary General of the Ministry of Forestry and Wildlife (Mr Koulagna Koutou Denis), visited China from 19-29 July 2009, to explore cooperation with INBAR and to study the Chinese experience in developing its bamboo sector. There was also a strong presence and interest from the Cameroon Government delegation and actors from the sector at the International Workshop on Enhancing Opportunities for Market-Led Bamboo and Rattan Based Development in West and Central Africa, held 23-25 November 2009 in Yaoundé and organised by INBAR, ICRAF and regional partners.

\section{Regulations}

Regulation and policy in Cameroon does not address bamboo specifically, rendering it an 'invisible product'. It is not mentioned within the framework of the forestry and environmental laws in Cameroon (1994 Forestry Law or 1996 Framework Environmental Law), either as a timber or non-timber forest product. It is not listed as a Special Forestry Product in the Decree of 2006 nor has it ever been included in the annual lists of special forestry products. The most recent and comprehensive reviews of NTFPs in Cameroon did not address bamboo at all (Betti 2007; FAO, GTZ, and COMIFAC 2008).

The 1994 Forestry Law addresses the issue of resource rights removed by the 1974 Land Ordinance, by providing customary user rights (droit d'usage) to forest communities. These rights allow communities to collect 'all forest, wildlife, fisheries products freely for their personal use, except protected species' (Forestry Law 1994, Section 8). This right can be exercised in all unprotected areas, and includes subsistence fuel wood and wood for construction. Timber sales are not included as a user right. Instead, it is regulated under systems of smallholder titles or through the community forestry process created by the 1994 law. Several articles in this law are relevant to the bamboo PCS;

Article 40 indicates that an inventory of forest resources is a prerogative of the State, but the State has not conducted an inventory of bamboo.
This study indicates that an inventory (along the lines proposed for timber exploitation) would be difficult given the dispersed nature of bamboo across Cameroon.

Article 43 states that the Government can mark and preserve any tree that it judges useful for conservation or regeneration needs, in an area intended for exploitation. The definition of a tree might present some problems for how bamboo is dealt with, as it is, strictly speaking, a grass.

Articles 45 to 74 concern timber exploitation in production forests and granting authorisation to exploit, for a fixed period, a precise volume of standing timber which may not exceed the annual logging potential. Again, the use of the term 'timber' effectively excludes bamboo.

The Ministry of Forestry and Wildlife (MinFoF), together with a range of stakeholders, is currently revising the 1994 Law. MinFoF has indicated that it is considering how and where to deal with bamboo. Some of the issues raised by stakeholders during interviews and during the INBAR November 2009 workshop in Cameroon, and possible solutions, are listed in Table 43.

\section{Customary rules}

Customary, local management practices are known from the Kilum Ijum forests areas in the Northwest (obsIngram personal observation, (Cunningham et al. 2002). The local communities around the forest have traditionally depended a great deal on the forest for secondary forest products, especially firewood, medicinal plants, beekeeping and bamboo. This is epitomised by the all-important role that the forest plays in the people's rich cultural life, and was institutionalised in agreed forest-wide rules for the Fondoms of Kom, Oku and Nso for the KilumIjim forest (held at Oku from 6 January 1999 to 3 March 1999), the process of which was supported by the Bamenda Highlands Forest Project. Livestock keeping (cattle and goats) inside the forest on $\mathrm{Mt}$ Oku was banned by both the traditional authorities and the government administration in the 1990s but is now practised by a few 'elite' individuals. Some unsustainable forest exploitation practices have long been controlled by the region's Traditional 
Table 43. Legal and regulatory issues and recommendations

\begin{tabular}{|c|c|}
\hline Issue & Recommendation \\
\hline $\begin{array}{l}\text { 1. Classification } \\
\text { As bamboo is largely used in a similar } \\
\text { way to timber (e.g. construction, } \\
\text { furniture, fuel), should it be classed as a } \\
\text { timber species and treated in the same } \\
\text { way? Or should it be classed as a NTFP? }\end{array}$ & $\begin{array}{l}\text { Bamboo is a member of the grass family and is not a tree species. The } 1994 \text { law does } \\
\text { not, however, make a distinction between forestry products based on their species } \\
\text { or woodiness or non-timber forest product. The main distinctions for forest products } \\
\text { (Forestry Law 1994, Section 9(2)) are based on 'value': certain forest products, such as } \\
\text { ebony, ivory, wild animals, as well as certain animal, plant and medicinal species or those } \\
\text { which are of particular interest and shall be classified as special. }\end{array}$ \\
\hline $\begin{array}{l}\text { 2. Trade or subsistence } \\
\text { It is not a heavily exploited or large } \\
\text { volume, high value heavily traded } \\
\text { product, in comparison with much } \\
\text { more widespread NTFPs that have } \\
\text { known markets and a long history of } \\
\text { exploitation NTFPs (e.g. Gnetum (okok), } \\
\text { Irvingia spp., Dacryodes edulis (safou), } \\
\text { Raphia spp., etc). }\end{array}$ & $\begin{array}{l}\text { Given the small, mainly local use and trade; the use of predominantly exotic (introduced) } \\
\text { species; and the agroforestry, semi-cultivated nature ( } 33 \% \text { of bamboo is owned, and } \\
35 \% \text { is managed or planted), it could be considered a crop more than a forest product. } \\
\text { An argument can therefore be made to maintain bamboo harvesting as a customary } \\
\text { user right. } \\
\text { An exception may be in non-protected areas where native species occur, but the } \\
\text { resource maybe under threat (e.g. Kilum ljum forest). However, when customary } \\
\text { management, user and collection rights provide sufficient control and the quantities are } \\
\text { small, the threat may be judged as sufficiently low and harvest permitted. }\end{array}$ \\
\hline $\begin{array}{l}\text { 3. Use } \\
\text { Bamboo's main use in furniture and } \\
\text { construction suggests that bamboo } \\
\text { should be treated as timber equivalent. }\end{array}$ & $\begin{array}{l}\text { Bamboo is used in a similar way to timber (for construction, furniture and crafts) and for } \\
\text { fuelwood. Timber, however, is not regulated in Cameroon according to end-use but due } \\
\text { to its economic value (specifically export value), with certain species assigned specific } \\
\text { tax values (Article 66). If treated as timber, revisions may need to be made; for example, } \\
\text { bamboo is not listed as requiring a fFelling tax (Tax d'abbatage). However, given the low } \\
\text { price of bamboo poles (200-1000 FCFA), a tax per pole would be difficult to implement } \\
\text { both socially and economically. }\end{array}$ \\
\hline $\begin{array}{l}\text { 4. Threats } \\
\text { Bamboo is not currently listed or } \\
\text { recognised as a threatened, protected } \\
\text { or endangered species and is not a } \\
\text { CITES listed product }\end{array}$ & $\begin{array}{l}\text { 4.1 The main species used in larger volumes and preferred species for trade are exotic, } \\
\text { introduced species of Bambusa vulgaris. While harvesting levels in some local areas may } \\
\text { not be sustainable, this exotic species is not under threat and regenerates easily. No } \\
\text { special conservation or protection measures are therefore recommended. } \\
4.2 \text { As bamboo also provides food for wildlife, it may be a suitable species to promote } \\
\text { in protected areas and buffer zones to avoid damage to crops by browsing elephants. } \\
\text { Equally, it may attract elephants out of protected forest into less protected buffer zones } \\
\text { where they can be hunted more easily. } \\
4.3 \text { An exception may be the Alpine bamboo (Yushina alpina) in the Highlands. This may } \\
\text { be under threat from conversion of forest to grazing pasture and farmlands, fires and } \\
\text { degradation due to over-exploitation (Cheek et al. 2000, Ayodele and Tsi } 2002 \text {, Solefack } \\
\text { 2009). Monitoring changes in the area and density of montane Bamboo in the Highland } \\
\text { areas, particularly Kilum ljum, is therefore recommended. }\end{array}$ \\
\hline
\end{tabular}

Authorities. Recognising the grazing problem, in July 1993 the Oku Clan Council decreed that all domestic animals should be removed from the forest. Finally, a Prefectural Order (an Administrative Order issued by the Senior Divisional Officer, Government of Cameroon) was passed in 1993, which prohibited the following activities within the forest boundary: lighting bushfires, tree felling, cutting young alpine bamboo, farming, hunting/trapping animals in the forest reserve (unless rats, using traditional methods) and rearing and grazing domestic animals. Rule No 16 stipulates that only mature or dry Indian bamboos should be cut. In cases where fresh young bamboos are needed, the community must be consulted. Thus, both the traditional authorities and the Government recognise that grazing livestock within the forest boundary is detrimental to the long-term survival of the forest and montane vegetation.

Also in the Northwest, around Bafut, where 'wild' and planted bamboo exist, strict control and regulations for harvesting are enforced by the local chief, the Fon. In most cases, these result in monetary fines and payments for rights to harvest. Around Ngoundal in Adamaoua, where bamboo is an integral material for traditional beehives, there are no customary rules for small-scale harvesting and most bamboo is located in 'open access' forests. In only one village, where there are no beekeepers but several large clumps of bamboo, have beekeepers from neighbouring Wendoka made arrangements with the village chief to harvest and collect cuttings for transplant to riverine areas nearer their village, to ensure security of their resource.

Reports (Tcahana and Mboui personal communication, (Soukontoua, Mfomou, and Howard 2007) of customary use in the Ngoundal area of Adamaoua indicate that the declining quantity of the resource and increasing distance villagers have to travel to harvest it, have encouraged recent protection of bamboo groves. Regeneration efforts in land demarcated as community regeneration zones that are protected specially for 
Raphia and bamboo under order of the local chief, with agreement of the villagers, have been introduced in the last 2 years in four villages around Ngoundal.

\section{Institutional and administrative framework}

The institutional framework guiding bamboo and its exploitation in Cameroon is weak because of the lack of competent authority, law and regulations.

If bamboo was considered a forest product, it would fall under the auspices of the Ministry of Forestry and Wildlife. As there is no definition of timber and non-timber forest products, there is no obvious classification category for bamboo in the current framework. Due to the relatively current small size and local trade of bamboo - compared to other non-timber forest products and timber in Cameroon (Ingram 2009) - it does not appear either beneficial to MinFoF or the sector to include bamboo on the list of Special Forestry Products.

Bamboo could alternatively be considered as an agricultural product, due to its frequent occurrence as a planted crop. In this case, the institutional framework would be under the Ministry of Agriculture and Rural Development.

The Ministry for Small and Medium Enterprises, Social Economy and Craftspersons (MinPME) has interactions with craftspeople and traders in bamboo and rattan, partially in Littoral around Douala, and in the Northwest around Bamenda. While this is general support for small enterprises, it has been recognised that the small furniture producers provide livelihoods and respond to consumer demand for both cheap and increasingly higher quality furniture (Pers comm delegate MinPME).
The main organisation associated with craft and furniture bamboo products in Cameroon is the Cameroon National Corps of Craftspersons/Corps National des Artisans (CNAC). This federation of regional associations has member unions and CIGs in the West, Littoral and Northwest regions working with cane and bamboo products.

While certification of bamboo is not common worldwide, certification according to Forest Stewardship Council (FSC) standards is in progress for bamboo by SKAL International in India (Burgener 2007). Burgener (2007) and Shanley (2008) both note the difficulties in certification of non-timber products, particularly when they are traded on a small-scale in local markets. However, in the case of bamboo in Asia, where it is traded internationally, it is often for specific industries (namely food and construction) and is on a large scale. However, for popular NTFPs such as palm hearts, brazil nuts and some medicinal plants, certification has greater potential. Bamboo and rattan were seen as resources with such potential, but as the trade in bamboos from Africa is on such a small-scale (INBAR/BOTA/ABS 2009), a case by case basis is necessary and it is difficult to say how useful it is for such a wide group of products included in NTFP.

In Cameroon there is no known certification for bamboo or its products, although FSC standards for timber exist with some $11 \%$ of forest concessions covered. FSC standards have been developed — but not yet applied - for community forest timber in Cameroon but not for any other forest products. The only organic certification that currently exists in Cameroon is for an agricultural product (French EcoCert for pineapples). For forest products, honey has been certified as organic by the UK Soil Association since 2008. In the last decade in Cameroon, a number of agricultural products such as cocoa, coffee and cotton, apiculture products and handicrafts have been fair trade-certified. 



\section{Development opportunities and ways forward}

\section{Developing the Cameroon bamboo sector}

To map out development opportunities for the bamboo PCS, actors were asked questions such as 'What should be done to enhance the bamboo industry in the country?', 'How do you see the market in the future?', 'As a consumer, what improvements in the transformation of bamboo are needed?', and 'Do you need any urgent technical assistance?' When collectors were asked the general question as to what could be done to enhance the overall bamboo industry, most of them $(64 \%)$ indicated a need for open, good training centres for bamboo-based activities; $23 \%$ stated the need to make the public aware of how to regenerate bamboo, while $13 \%$ suggested the construction of warehouses and sales centres. Processors also indicated the need for training centres (70\%) and publicity campaigns $(10 \%)$ and for direct financial assistance $(20 \%)$. Traders mentioned the need to stimulate demand (3\%) and increase customer awareness of bamboo products (74\%), and believed business was slow, giving few chances for development. In addition to these suggestions, consumers added the dimension of producing more attractive products $(51 \%)$, capacity building and raising the awareness of consumers about bamboo products (39\%) and the need for sustainable management (10\%). Combining these responses into common categories, four main themes can be seen, with the priority being marketing and raising consumer awareness of products, their uses and values, followed by training and capacity building of processors and harvesters (Figure 43).

Among the 38 processors interviewed, 63\% expressed the need for technical assistance while the rest were indifferent. For those wanting assistance, 67\% named cleaning machines, $17 \%$ cutters and splitters while $8 \%$ each stated that vehicles for transporting raw materials and products and shaping machines are most needed. Processors indicated that assistance could be sourced from NGOs (25\%) and purchases from local or urban markets (75\%). No mention was made of the Government as a source of support for the sector.

\section{Recommendations}

Drawing on the actors' suggestions, the study findings and the November 2009 workshop, the following recommendations are proposed as next steps to develop Cameroon's bamboo sector:

1. Given the lack of data on the availability of both native and introduced species, inventories

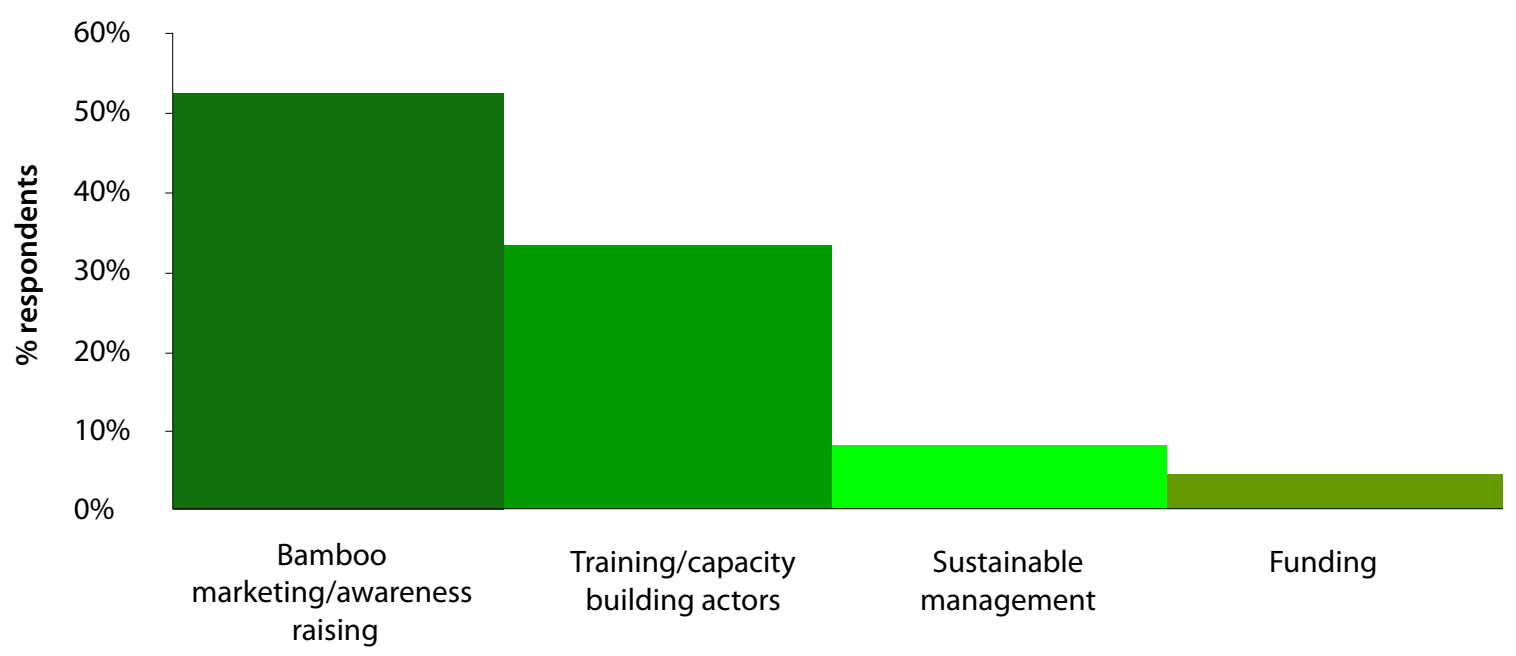

Bamboo sector development opportunities

Figure 43. Development opportunities proposed by actors 
are essential for long term, sustainable resource management. The minimum data required is an inventory of the quantity and species found in the main production areas. A national level inventory of bamboo resources across Cameroon is advised to provide a complete picture.

2. Regeneration does not appear to be a major priority, given current market demand and availability of resources. However, if more emphasis is placed on the consumption and production side of the chain, resulting in increased demand, it is essential that regeneration and management of bamboo resources occurs in parallel with marketled development. The sustainable harvest guidelines proposed need to be tested and tried to support adequate regeneration. Particulate emphasis should be placed on the species for regeneration with a conscious selection of both native and introduced species depending on the end use.

3. Although neither of the two native African bamboo species are classified as endangered, for alpine bamboo (Yushina alpina), the level of threat and species vulnerability needs to be assessed. This is important given the high level of deforestation and degradation threat to the habitats where most of this species is located in the Bamenda Highlands.

4. As bamboo is easily grown, agroforestry and domestication appears a feasible, low cost, potential route to ensure long term sustainable bamboo supply and management. A route which has proved successful for other NTFPs in Cameroon is disseminating germplasm from suitable species, combined with training of harvesters, owners and farmers in domestication, nursery and propagation techniques. A good partnership between INBAR, ICRAF, local nurseries and ANAFOR already exists which could support this activity technically

5. As just under half of bamboo harvested is open access, the tenure of land containing bamboo and ownership of specific bamboo clumps made need clarification (in common with other forested areas which communities believe are their lands), as bamboo becomes more valuable.

6. Bamboo has been shown to contribute significantly to the livelihoods of a small number of harvesters, processors and traders. Revenues from bamboo are also used to meet mainly basic needs and therefore can be seen as a contribution to attain the Millennium Development Goals. Developing the PCS to increase the number of those employed and their incomes is recommended based on a value chain approach that encompasses the entire PCS chain. A fuller baseline is needed of the numbers of people involved across Cameroon. Attention can also be particularly focused on the weakest links in the PCS chain by:
a. Introducing suitable species for different and multiple uses.
b. Increasing consumer and processor awareness of bamboo's properties and multiple uses.
c. Increasing the product range and design.
d. Support for innovations in design and processing.
e. Professionalisation and training of actors - particularly harvesters and marketing.
f. Business training and competitive pricing.
g. Addressing problem areas, particularly storage.

7. Increasing the currently limited product range and the basic marketing methods indicates an untapped market potential. Learning lessons from both innovative design, appropriate materials and the range of uses and designs from leading countries in Asia could aid in diversifying incomes, adding value to products and the prestige of bamboo in general.

8. Consumer attitudes to bamboo highlight that many customers are positive about bamboo and believe its products are high quality, but believe it is not durable and less attractive than equivalent materials. A marketing campaign using the knowledge of producers and harvesters, and targeted particularly at consumers in the major urban markets, address these perceptions and improve bamboo's image, together with improved product design, treatment and selected species to address durability issues.

9. The enabling environment in terms of potential partner organisations in Cameroon is positive, despite their current lack of involvement in the sector. There is interest from the two main competent Ministries of Forestry and Wildlife and Small and Medium Scale Enterprises. Additional government stakeholders such as the Ministry of Agriculture and Rural Development could be beneficial partners. Funding agencies and development partners could potentially include those focusing on themes such as artisan crafts, building materials, biofuels and renewable energy, reforestation and carbon sequestration and rural development. For the native bamboo, forest and conservation organisations could also be potential partners. Public-private partnership and investment from foreign processors of bamboo products could provide a boost by acting as a pilot or demonstration model for the sector.

10. The majority of stakeholders in the bamboo chain operate informally and are both unregistered and unorganised, although the number of groups appears to be increasingly recently with 
support from the Ministry of Small and Medium Scale Enterprises, and an improved business environment. Efforts to professionalise the sector could be successful when they address common goals and needs such as marketing, consumer education on bamboo and its products and uses, crafts training and business skills development. Problems of safety and accidents due to inappropriate tools could also be addressed by collective action and organisation which may increase access to credit, enabling harvesters and processors to buy better equipment.

11. A change is needed in the current 'silent' policy framework concerning bamboo by the Ministry of Forestry and Wildlife and ANAFOR, to a more active promotion of bamboo. Clarification of its non-special status is advised. Given that largely exotic species are used, the current low level and estimated minor total volume and value of trade (compare to other non-timber and timber products) and its importance for subsistence use, indicate that bamboo's classification as a special forestry product is not necessary. As bamboo tends to be as much a planted as a wild forest product (in the major production areas in the Southwest, Centre and Littoral regions), the involvement of the Ministry of Agriculture and Rural Development and other stakeholders in agriculture, could enhance the domestication of bamboo in Cameroon.

12. Opportunities exist to use bamboo's ecological characteristics positively to combat soil erosion and capture carbon, particularly in areas of degraded soils and eroded land such as the West, Northwest and Adamaoua, and in carbon sequestration and reforestation projects such as REDD. 



\section{References}

Abott, J.I.O., Thomas, D.H.L., Gardner, A.A., Neba, S.E. and Khen, M.W. 2001 Understanding the links between conservation and development in Bamenda Highlands, Cameroon. World Development 29: $1115-1136$

Ames, M. 1998 Assessing the profitability of forestbased enterprises. In: Wollenberg, E. and Ingles, A. (eds) Incomes from the forest: methods for the development and conservation of forest products for local communities. CIFOR, Bogor, Indonesia.

Arnold, J.E.M. and Ruiz-Pérez, M. 1998 The role of non-timber forest products in conservation and development. In: Wollenberg, E. and Ingles, A. (eds) Incomes from the forest: methods for the development and conservation of forest products for local communities, p17-42. CIFOR, Bogor, Indonesia.

Ayodele, I.A. and Tsi, E.A. 2002 Forest fragmentation and the loss of birds, an issue of immediate attention at Kilum-Ijum Community Forest, Cameroon. Nature et Faune 18.

Belcher, B. and Schreckenberg, K. 2007 Commercialisation of non-timber forest products: a reality check. Development Policy Review 25(3): 355-377.

Belcher, B.M. 1998 A production to consumption systems approach: lessons from the bamboo and rattan sectors in Asia. In: Wollenberg, E. and Ingles, A. (eds.) Incomes from the forest: methods for the development and conservation of forest products for local communities, p56-84. CIFOR, Bogor, Indonesia.

Betti, J.L. 2007 Stratégie/plan d'action pour une meilleure collecte des données statistiques sur les produits forestiers non ligneux au Cameroun et recommandations pour les pays de la COMIFAC. Project report. http://cameroun-foret.com/system/ files/18_89_76.pdf (30 September 2010).

Brink, M. 2008 Bambusa vulgaris Schrad. ex Wendl, J.C., Protabase. In: Louppe, D., Oteng-Amoako, A.A. and Brink, M. (eds) Plant Resources of Tropical Africa/Ressources végétales de l'Afrique tropicale. Wageningen, Netherlands.

Burgener, M. 2007 Trade measures - tools to promote the sustainable use of NWFP? An assessment of trade related instruments influencing the international trade in non-wood forest products and associated management and livelihood strategies. Non-Wood Forest Products Working Document $\mathrm{N}^{\circ} 6$ F. Department: 145. Food and Agriculture Organization, Rome.
Bystriakova, N., Kapos, V. and Lysenko, I. 2002 Potential distribution of woody bamboos in Africa and America. In: Working Paper 43, United Nations Environment Program-World Conservation Monitoring Centre (UNEP-WCMC), Cambridge, UK.

Cable, S. and Cheek, M. 1998 (eds.) The plants of Mount Cameroon - a conservation checklist. Royal Botanic Gardens, Kew, UK.

Calibre Consultants and Statistical Services Centre at the University of Reading 2000 Numbers of forest dependent people: a feasibility study. In: DFID's Forestry Research Programme. University of Reading, Reading, UK.

CERUT-AIDEnvironment 1999 The wealth of forests in Cameroon. In: Results of field testing: a methodology for the valuation of non-timber forest products (NTFPs) in North-West and South-West Cameroon, 137. CERUT and AIDEnvironment.

Cheek, M., Onana, J. and Pollard, B. 2000 The plants of Mount Oku and the Ijim Ridge, Cameroon: a conservation checklist. Royal Botanic Gardens, Kew, UK.

Cheek, M., Pollard, B.J., Darbyshire, I., Onana, J.-M. and Wild, C. 2004 The plants of Kupe, Mwanenguba and the Bakossi Mts, Cameroon - a conservation checklist. Royal Botanic Gardens, Kew, UK.

Central Intelligence Agency 2010 World Factbook, Cameroon, https://www.cia.gov/library/ publications/the-world-factbook/geos/cm.html (7 June 2010).

Clark, L.E. and Sunderland, T.C.H. 2004 The key nontimber forest products of Central Africa: state of the knowledge. In: Clark, L.E. and Sunderland, T.C.H. (eds) SD Publication Series Technical Paper 122. US Agency for International Development, Office of Sustainable Development, Bureau for Africa, Washington, DC.

Comiskey, J.A., Sunderland, T.C.H. and SunderlandGroves, J. (eds) 2003 Takamanda: the biodiversity of an African rainforest. Smithsonian Institution, Washington, DC.

CBFP (Congo Basin Forest Partnership) 2006 The Forests of the Congo Basin, State of the Forest 2006. COMIFAC, Yaoundé, Cameroon:. http://www.cbfp. org/ (30 September 2010).

CRAC/GTZ-MINEF 1999 Note de conjoncture environnement. Document for the project 'Conseiller auprès du Ministère de l'Environnement et des Forêts (MINEF)'. Gesellschaft für Technische Zusammenarbeit (GTZ), Yaoundé, Cameroon. 
Cuddeford, V. 2007 Fiche descriptive sur le bambou. Réseau de radios rurales des pays en développement, Pochette 80 (4) March 2007.

Cunningham, A.B., Ayuk, E., Franzel, S., Duguma, B. and Asanga, C. 2002 An economic evaluation of medicinal tree cultivation: Prunus africana in Cameroon. People and Plants Working Paper 10: 1-39.

Dione, A.M., Tamnjong, I., Ndam, N. and Blackamore, P. 2000 Socio-economic case study of the productionto-consumption system of the rattan sector in Cameroon. International Network for Bamboo and Rattan http://www.inbar.int (20 September 2010).

Doumenge, C., Gilmour, D., Ruiz-Pérez, M., Blockhuis, J., 1993 Tropical montane cloud forests: conservation status and management issues. http://horizon. documentation.ird.fr/exl-doc/pleins_textes/pleins_ textes_6/b_fdi_35-36/41295.pdf (20 September 2010).

European Tropical Forest Research Network (ETFRN) 2003 Mountain forests. ETFRN News. http://www. etfrn.org/etfrn/newsletter/news38/nl38_oip.html (20 September 2010).

Food and Agriculture Organisation (FAO) 2010 Forests and poverty reduction website. http://www.fao.org/ forestry/livelihoods/en/ (6 June 2010).

Food and Agriculture Organisation (FAO) 2003 Bamboo and rattan statistics. Non-Wood News 10: 104. FAO, Rome.

Food and Agriculture Organisation (FAO) 2007 State of the world's forests. FAO, Rome.

Food and Agriculture Organisation (FAO), Gesellschaft für Technische Zusammenarbeit (GTZ) and COMIFAC 2008 Directives sous-régionales relatives a la gestion durable des produits forestiers non ligneux d'origine végétale en Afrique Centrale. In: GCP/RAF/398/GER Renforcement de la sécurité alimentaire en Afrique Centrale à travers la gestion et l'utilisation durable des produits forestiers non ligneux. Yaoundé, Cameroon.

Foaham, B., Samba D., Ingram, V. and Awono, A. 2009 Inventaire de Prunus africana dans les provinces du Sud-ouest et du Nord-ouest du Cameroun, novembre 2007 - novembre 2008. CIFOR, Yaoundé, Cameroon.

Fometé, T. and Cerutti P. 2008 Verification in the forest sector in Cameroon. Verifor Country case study 11., Overseas Development Institute, London.

Gautier, D. 1992 Bamiléké hedges and agriculture: an example from the Bafou district (W. Cameroon). Cahiers de la Recherche Developpement 31(1): 65-78.

Government of Cameroon 2010 Third Population and Housing Census 2005. Government of Cameroon, Yaoundé, Cameroon

Grimshaw, J.M. 1999 The afromontane bamboo, Yushania alpina, on Kilimanjaro. Journal of East African Natural History 88: 79-83.
Hall, J.B. and Inada, T. 2008 Sinarundinaria alpine (K.Schum.) C.S. Chao and Renvoize, Protabase. In: Louppe, D., Oteng-Amoako, A.A. and Brink, M. (eds.) PROTA (Plant Resources of Tropical Africa/Ressources végétales de l'Afrique tropicale). Wageningen, Netherlands.

Hawkins, P., and Brunt, M. 1965 The Bamenda area, vegetation map, map 9. In: The soils and ecology of west Cameroon (with special reference to the Bamenda Area). Food and Agriculture Organiszation, Rome.

Holmes, Karen (ed.) 2005 Interactive forestry atlas of Cameroon: an overview. World Resources Institute, Washington, DC.

Hutchinson, J., Dalziel, J., Keay R.W.J. and Hepper, F.N. 1954-1972 Flora of West Tropical Africa, Vols 1-3. Whitefriars, London and Tonbridge, UK.

INBAR/BOTA/ABS (International Network for Bamboo and Rattan - Bamboo of the Americas - American Bamboo Society) 2009 Constructing and conserving with bamboo. Round Table Discussion at World Forestry Congress 13, Buenos Aires, Argentina, 18-23 October 2009. http://www. bamboooftheamericas.org/? $\mathrm{p}=138$

(30 September 2010).

International Network for Bamboo and Rattan (INBAR) 2009 Ochlandra travancorica: INBAR.http://www.inbar. int/publication/txt/tr17/Ochlandra/travnacorica.htm (November 2009).

Ingram, V. and Jam, A.N. 2008 Cameroon Highlands ecomonitoring and survey results 2006-2007. Working paper. Western Highlands Conservation Network (WHINCONET) and Netherlands Development Organisation (SNV), Bamenda, Cameroon.

Ingram, V. 2009 The hidden costs and values of NTFP exploitation in the Congo Basin. Paper presented at the 13th World Forestry Congress. Buenes Aires, Argentina, 18-23 October.

Jonkers, W.B.J. and Foaham, B. 2004 Sustainable management of rainforest in Cameroon. TropenbosCameroon Series 9. Tropenbos International, Wageningen, Netherlands.

Jonkers W.B.J. and Foahom B. 2009 Sustainable management of rainforest in Cameroon. The Tropenbos-Cameroon Programme, Kribi. TropenbosCameroon Series 9.

Kaberry, P.M. 1952 Women of the grassfields: a study of the economic position of women in Bamenda, British Cameroons. Her Majesty's Stationery Office, London.

Kilum Ijum Forest Programme 1997 Kilum- Ijim Forest Project: Plant List. Ecological Monitoring Programme. Birdlife International 15.

Kleinn, C., Yang, Y., Weyerhäuser, H. and Stark, M. 2006 The sustainable harvest of Non-Timber Forest Products in China. Strategies to balance economic benefits and biodiversity conservation. Paper presented at SinoGerman Symposium at Bejing. 
Knopfli, H. 2001 Baskets and Calabashes, Palms and People. Basel Mission, Basel.

Laird, S., Ingram, V., Awono, A., Ndoye, O., Sunderland, T.C.H., Lisinge, E. and Nkuinkeu, R. 2010 Bringing together customary and statutory systems: the struggle to develop a legal and policy framework for NTFPs in Cameroon. In: Laird, S.A., McLain, R. and Wynberg, R.P. (eds.) Wild product governance: finding policies that work for NonTimber Forest Products. Earthscan, London.

Laird, S.A., McLain, R. and Wynberg, R.P. (eds.) 2010 Wild product governance: finding policies that work for Non-Timber Forest Products. Earthscan, London.

Lauber, W. 1990 Palaces and compounds in the grasslands of Cameroon: traditional wood architecture of a West African country. Karl Krämer \& Co. Verlag, Zurich, Switzerland.

Letouzey, R. 1985 Carte Phyogeographique du Cameroun 1:500 000. I. d. l. R. Agronomique. Toulouse, France.

Maisels, F. and Forboseh, P. 1999 Phenology of the major tree and shrub species of the Kilum Ijim forest. Ecological Monitoring Programme. K.-I. F. Project. Cameroon, BirdLife International and the Ministry of Environment and Forestry.

Malin, N. and Boehland, J. 2006 Bamboo construction: is the grass always greener? Environmental Building News, March 2006.

Marsh, J. and Smith, N. 2006 New bamboo industries and pro-poor impacts: lessons from China and potential for Mekong countries. In: Oberndorf, R., Durst, P., Mahanty, S., Burslem K. and Suzuki, R. (eds) A cut for the poor - International conference on managing forests for poverty reduction: capturing opportunities in forest harvesting and wood processing for the benefit of the poor. Food and Agriculture Organisation (FAO), Netherlands Development Organisation (SNV), the Center for People and Forests (RECOFTC), Ho Chi Minh City, Vietnam.

Mdaihli, M., Schmidt-Soltau, K. and Ayeni, J.S.O. 2002 Socioeconomic baseline survey of the villages in and around the Takamanda Forest Reserve. Program on Forests (PROFOR):54.

Mundi, E.K. 1978 Construction and building materials industry in the United Republic of Cameroon. International Forum on Appropriate Industrial Technology, New Delhi/Anand, India.

Neba, A. 1999 Modern geography of the Republic of Cameroon. $3^{\text {rd }}$ ed. Neba, Bamenda, Cameroon .

Nkwatoh, A.F. 2005 Production and marketing of non timber forest products (NTFPs), a major source of rural and national income in the South West Province of Cameroon. 17th Commonwealth Forestry Conference, Colombo, Sri Lanka, 25 February - 5 March 2005.

Nurse, M.C., Mckay, C. R., Young, J.T. and Asanga, C.A. 1995 Biodiversity conservation through community forestry, in the montane forests of Cameroon. Rural Development Forestry Network (RDFN) paper.

Ohrnberger, D. 1999 The bamboos of the world. Elsevier, Amsterdam the Netherlands..

Pabuayon, I.M. 2009 The changing market for NWFPs and strategic directions for the bamboo and rattan sector. $13^{\text {th }}$ World Forestry Congress Buenos Aires, Argentina, 18-23 October 2009.

Parrott, J, and Parrott, H. 1989 Report on the conservation of Prunus (Pygeum) africanum in Cameroon. In: Report, Kilim Ijum Forest Project. Kilum Mountain Forest Project, Bamenda, Cameroon.

Preston, G.N. 1981 Africa's Cross river: art of the Nigerian-Cameroon border redefined. African Arts 14(3): 78-79.

Rajahmundry 2003 Bamboo harvesting and marketing in VSS areas in North Coastal districts. Paper presented at workshops 17-18 October and 14-15 November, PMRC, Rampachodavaram, East Godavari District, India. http://forest.ap.nic.in/JFM\%20CFM/CFM/ Special\%20Reports/VSS\%20Worskhops\%20on\%20 Bamboo\%20Harvesting.htm (30 September 2010).

Ruiz-Pérez, M. and Byron, N. 1999 A methodology to analyse divergent case studies of Non-Timber Forest Products and their development potential. Forest Science 45(1): 1-14.

Ruiz-Pérez, M., Belcher, B., Fu, M. and Yang, X. 2004 Looking through the bamboo curtain: an analysis of the changing role of forest and farm income in rural livelihoods in China. International Forestry Review 6(3-4): 306.

Ruiz-Pérez, M., Maoyi, F., Belcher, B., Xioasheng, Y., Mertens, B., Hua, L. and Jinzhong, X. 2009 The socio-economic and environmental roles of bamboo in rural China. In: Abe Kem-ichi, J.E.N. Good earths: regional and historical insights into China's environment. Kyoto University Press and Trans Pacific Press, Melbourne, Australia.

Soukontoua, Y., Mfomou, E. and Howard, R. [2007] Report of the socio-economic study based on beekeeping in Adamoua. Paella, E. Cameroon, Ngoundal, 31. Unpublished report

Shanley, P., Pierce, A., Laird, P. and Robinson, D. 2008 Beyond timber: certification and management of Non-Timber Forest Products. CIFOR, Bogor, Indonesia.

Sunderland, T.C.H. 2001 The taxonomy, ecology and utilisation of African rattans (Palmae: Calamoideae). University College, London, UK.

Sunderland, T.C.H., Besong, S. and Ayeni, J.S.O. 2002 Distribution, utilisation and sustainability of Non-timber Forest Products from Takamanda Forest Reserve, Cameroon. In: Consultancy Report, Protection of the Forests around Akwaya (PROFA). http://cameroun-foret.com/fr/system/files/18_89_04. pdf (20 September 2010). 
Tabot Tabot, Ebenezer 2006. Strengthening forward and backward linkages in the Rattan and Bamboo sectors in Africa: the case of South West Region of Cameroon. Paper presented at ITTO/ ICBR / INBAR International Workshop on Sustainable Development of Global Rattan Sector, 1st Bamboo and Rattan Standardization Training Workshop, 23-27 July, Beijing, China.

Tchoundjeu, Z., Atangana, A.R. and Degrande, A. 2005 Indigenous methods in preserving bush mango kernels in Cameroon. American Journal of Applied Sciences 2(9): 1337-1342.

Tieguhong, J.C. and Ndoye, O. 2004 Development of trade and marketing of non-wood forest products for poverty alleviation in Africa. A report prepared for the project Lessons Learnt on Sustainable Forest Management in Africa. CIFOR,

Yaoundé, Cameroon.

Tieguhong, J.C. Ndoye, O. Vantomme, P., Zwolinski, J. and Masuch, J. 2009 Coping with crisis in Central Africa: enhanced role for non-wood forest products. Unasylva 233(60): 49-54.

Topa, G., Karsenty, A., Megavand, C. and Debroux, L. 2009 The rainforests of Cameroon: experience and evidence from a decade of reform. In: Directions in development. Environment and sustainable development. World Bank, Washington, DC.

Transparency International 2009 Corruption Perceptions Index 2008. Transparency International http://www.transparency.org/policy_research/ surveys_indices/cpi/2009 (20 May 2009).
United Nations Development Program (UNDP) 2008 Human development report 2007/2008. Fighting climate change: human solidarity in a divided world. UNDP, New York.

United Nations Development Program (UNDP) 2009 Human development report 2009. Overcoming barriers: human mobility and development. UNDP, New York.

van der Zon, A.P.M. 1992 Graminées du Cameroun. PhD dissertation no. 1511, Wageningen Agricultural University, Wageningen, The Netherlands.

Warnier, J.-P. 2006 Techniques du corps et esthétique de l'art royal en Afrique. Revue de Philosophie et de Sciences Humaines 17.

de Wasseige C., Devers, D., Marcken P., Eba'a Atyi R., Nasi R. and Mayaux Ph., (eds) 2009 The forests of the Congo Basin, State of the Forest 2008. Office des publications de l'Union Européenne, Congo Basin Forest Partnership, Yaoundé, Cameroon.

Wilkinson, K. and Elevitch, C. 2009 Non-timber forest products: an introduction. The Overstory 53.

World Bank 2002 Sustaining forests: a development strategy. Washington DC.

World Bank 2009 Doing Business. World Bank, Washington DC.

World Bank 2009 Cameroon at a glance. At a Glance Series. World Bank, http://web.worldbank.org/ wbsite/external/datastatistics/. 


\section{Appendices}

Appendix 1. List of actor and stakeholder interviews

\begin{tabular}{|c|c|c|c|c|}
\hline No & Name & $\begin{array}{l}\text { Organisation/ } \\
\text { Location }\end{array}$ & Contact/Email & Date \\
\hline 1 & Tole, Desire and Ewusi, Bruno & ANAFOR & $\begin{array}{l}\text { desiretole2005@yahoo.fr } \\
\text { desireiboureu@ymail.com }\end{array}$ & $\begin{array}{l}11-18 / 11 / \\
2009\end{array}$ \\
\hline 2 & Kwidja Roger & APADER & $\begin{array}{l}\text { Bangante } \\
99787771\end{array}$ & $24 / 11 / 09$ \\
\hline 3 & BOMBA Denis & APVF & Handicraft, Tunnel Mboppi 76384790 & $22 / 11 / 09$ \\
\hline 4 & $\begin{array}{l}\text { NG'AMOUGOU François } \\
\text { Marie }\end{array}$ & $\begin{array}{l}\text { Association de Protection et } \\
\text { Valorisation Forestière (APVF), GIC } \\
\text { PROFOPEC }\end{array}$ & Handicraft, Tunnel Mboppi 99256375 & $23 / 11 / 09$ \\
\hline 5 & VUNYOH Christopher & $\begin{array}{l}\text { Association des Artisans des } \\
\text { Produits Forestiers (ASAPROF) }\end{array}$ & Craftman, Nkol-Eton & 08/12/09 \\
\hline 6 & Lucien ATANGANA & $\begin{array}{l}\text { Association des Vanniers du } \\
\text { Mfoundi (AVAM) }\end{array}$ & Handicraft, Bastos 77207370 & $04 / 12 / 09$ \\
\hline 7 & Luc ONDOBO & $\begin{array}{l}\text { Association des Vanniers du } \\
\text { Mfoundi, Yaoundé }\end{array}$ & $\begin{array}{l}\text { Nouvelle route Bastos, between } \\
\text { UNDP office and Resto Fines Epices } \\
\text { lucondobo@yahoo.fr } 77881703\end{array}$ & $25 / 11 / 09$ \\
\hline 8 & EYEYA & ASVAM & Handicraft, Mvog-Mbi 77338499 & 05/12/09 \\
\hline 9 & MBIDA Antoine & ASVAM & Handicraft, Bastos & $05 / 12 / 09$ \\
\hline 10 & ONDOBO Luc & ASVAMF & $\begin{array}{l}\text { Handicraft, lucondobo@yahoo.fr, } 77 \\
8817 \text { 03, Omnisport }\end{array}$ & 08/12/09 \\
\hline 11 & YOR David & Badeng & Farmer, Bafoussam(Badeng) & 29/11/09 \\
\hline 12 & YOUBI Verdiane & Badeng & Farmer, Bafoussam(Badeng) & 29/11/09 \\
\hline 13 & KENGNE Jean Pierre & Badeng & $\begin{array}{l}\text { Farmer, Bafoussam(Badeng) } \\
74277450\end{array}$ & 29/11/09 \\
\hline 14 & KAGNE Chantal & Badeng & Farmer, Bafoussam(Badeng) & 29/11/09 \\
\hline 15 & TATOK & Badeng & $\begin{array}{l}\text { Farmer, Bafoussam (Badeng) } \\
94020131\end{array}$ & 29/11/09 \\
\hline 16 & TALLE Philippe & Badeng & Farmer, Bafoussam (Badeng) & 29/11/09 \\
\hline 17 & Abdouraman NAMEKONG & Bafoussam & Handicraft, Bafoussam 79743978 & 28/11/09 \\
\hline 18 & TIAM Zacharie & Bafoussam & Farmer, Bafoussam 94739444 & 28/11/09 \\
\hline 19 & KUETCHE Blaise & Bafoussam & Collecteur, Bafoussam 99818828 & $30 / 11 / 09$ \\
\hline 20 & POKAM B. & Bafoussam & Collecteur, Bafoussam 79579211 & $30 / 11 / 09$ \\
\hline 21 & TIYA Alain & Bafoussam & Handicraft, 99561714, Bafoussam & $30 / 11 / 09$ \\
\hline 22 & CHESOH George Ambe & Bafut & Bamboo, Bamenda (Bafut) 75081097 & $14 / 12 / 09$ \\
\hline 23 & Afuokeze NGUM & Bamenda & Handicraft, B'da 77384256 & $14 / 12 / 09$ \\
\hline 24 & MBARGA EVOUNA & Bamenda & Handicraft, Douala 95248798 & $23 / 11 / 09$ \\
\hline 25 & KOBONG Mercy & Bamenda Handicraft Cooperative & Manager, Bamenda & $14 / 12 / 09$ \\
\hline 26 & TEFO Maurice & Bastos & Handicraft, Bastos 77251984 & 04/12/09 \\
\hline 27 & Janvier MOKOUA & $\begin{array}{l}\text { Bimbia Bonadikombo Community } \\
\text { Forest }\end{array}$ & $\begin{array}{l}\text { Council office, Limbe } \\
\text { bbcommunityforest@yahoo.com }\end{array}$ & $18 / 02 / 10$ \\
\hline 28 & PENDA Max & Bokwango & Farmer, Buea (Bokwango) & $22 / 11 / 09$ \\
\hline 29 & PA NJIE Lium M. & Bokwango & Plumber, Bokwango & $22 / 11 / 09$ \\
\hline 30 & Luan NJIE & Bokwango & Farmer, Bokwango & $22 / 11 / 09$ \\
\hline 31 & Peter MANDALO & Bokwango & Farmer, Bokwango & $22 / 11 / 09$ \\
\hline 32 & MBOME Petet N & Bokwango & Driver, Bokwango & $22 / 11 / 09$ \\
\hline 33 & MOSOUGE Ernest & Bonakanda & Farmer, Bonakanda & $23 / 11 / 09$ \\
\hline
\end{tabular}




\begin{tabular}{|c|c|c|c|c|}
\hline No & Name & $\begin{array}{l}\text { Organisation/ } \\
\text { Location }\end{array}$ & Contact/Email & Date \\
\hline 34 & NJIE Ngando & Bonakanda & Farmer, Bonakanda & $22 / 11 / 09$ \\
\hline 35 & Gostave LIVANA & Bonakanda & Farmer, Bonakanda & $22 / 11 / 09$ \\
\hline 36 & Pete MBUA & Bwassa & Farmer, Bwassa & $24 / 11 / 09$ \\
\hline 37 & Njoh Augtine & Bwassa & Farmer, Bwassa & $24 / 11 / 09$ \\
\hline 38 & NCHIE Ikome & Bwassa & Farmer, Bwassa & $24 / 11 / 09$ \\
\hline 39 & Ebenzeer ТАВОТ ТАВОТ & CEHDev Cameroon & cehdev@justice.com & 06/11/09 \\
\hline 40 & LEKEADJO Cecile & $\begin{array}{l}\text { Centre de Promotion des Artisans } \\
\text { de Bafoussam (CEPAB) }\end{array}$ & $\begin{array}{l}\text { Gérante de la salle d'exposition } \\
\text { CEPAB, } 33027709 \text { / } 33444617 \text { / } \\
99312205 \text { cepab40@hotmail.com, } \\
\text { Bafoussam }\end{array}$ & $30 / 11 / 09$ \\
\hline 41 & MBIDA Celestin & Cercle des Jeunes de Zamakoe & Handicraft, Zamakoe & 02/12/09 \\
\hline 42 & MFOMO Gabriel & Cercle des Jeunes de Zamakoe & Handicraft, Zamakoe & 02/12/09 \\
\hline 43 & Terry SUNDERLAND & CIFOR & t.sunderland@cgiar.org & Nov. 2009 \\
\hline 44 & $\begin{array}{l}\text { Micheal TCHANA, Yves } \\
\text { SOUKONTANA, Paul MBOUI }\end{array}$ & Guiding Hope & guidinghope@yahoo.fr & 01/10/09 \\
\hline 45 & & CIRAD & & $25 / 02 / 10$ \\
\hline 46 & TEYTSA Alain & Douala & Handicraft, Tunnel Mboppi 96418875 & $24 / 11 / 09$ \\
\hline 47 & ESSOMBA Réné & Douala & Handicraft, Ndocbat 74435024 & 24/11/09 \\
\hline 48 & OUMAROU BOBO Jean & Douala & $\begin{array}{l}\text { Handicraft, Marche Tunnel Mboppi } \\
75742409\end{array}$ & $24 / 11 / 09$ \\
\hline 49 & DJOUMESSI & Douala & $\begin{array}{l}\text { Handicraft, Marché des fleurs } \\
5099140799\end{array}$ & $23 / 11 / 09$ \\
\hline 50 & ESSOMBA Afred Saker & Douala & $\begin{array}{l}\text { Handicraft, Douala Koumassi } \\
96033617\end{array}$ & $23 / 11 / 09$ \\
\hline 51 & Evaritus & Douala & Handicraft, marché des fleurs & $23 / 11 / 09$ \\
\hline 52 & ESSOMBA Hubert & Douala & Handicraft, Tunnel Mboppi & $23 / 11 / 09$ \\
\hline 53 & MBIDA Clavert & Douala & Handicraft, Tunnel Mboppi & $22 / 11 / 09$ \\
\hline 54 & MBESSEGUE AMBASSA & Douala & Handicraft, Tunnel Mboppi & $22 / 11 / 09$ \\
\hline 55 & ESSOMBA Norbert & Douala & Handicraft, Tunnel Mboppi & $22 / 11 / 09$ \\
\hline 56 & MBONGOLO Honoré & Douala & Handicraft, Bonapriso & $22 / 11 / 09$ \\
\hline 57 & NYANWA Réné & Douala & Handicraft, marché des fleurs & $22 / 11 / 09$ \\
\hline 58 & Ngembo MOTUTU & Ewonda & Farmer, Ewonda Village & $23 / 11 / 09$ \\
\hline 59 & Elvis Paul TANGEM & FAO & tangemelvispaul@yahoo.co.uk & $25 / 11 / 09$ \\
\hline 60 & Armand ZE Assenge & FAO & assengze@yahoo.fr & $24 / 11 / 09$ \\
\hline 61 & Irine Ako MANYI & FAO & irineako@yahoo.com & 05/10/09 \\
\hline 62 & NDONGO Leopold Aime & Ferrudjal & $\begin{array}{l}\text { Mbalmayo } \\
\text { leopoldaimendongo@yahoo.fr }\end{array}$ & $24 / 11 / 09$ \\
\hline 63 & FOTSO Alphonse & Foumbot & Cultivator, Foumbot & 28/11/09 \\
\hline 64 & NGON BA'A Idrissou & Foumbot & Famer, Foumbot & 29/11/09 \\
\hline 65 & AGBOR Justine & Foumbot & Farmer, Foumbot & 29/11/09 \\
\hline 66 & FANFON Adrian & Foumbot & Gardener, Foumbot & 28/11/09 \\
\hline 67 & Françoise & GIC ASCARTES & Yaoundé & 18/11/09 \\
\hline 68 & SEIDOU & GIC FAMROLI; Espace métier & $\begin{array}{l}\text { Handicraft, marché des fleurs } \\
74704014\end{array}$ & $23 / 11 / 09$ \\
\hline 69 & $\begin{array}{l}\text { Adjongo COME } \\
\text { DJOKO Martin } \\
\text { OTLU Ole, Joesph }\end{array}$ & GIC Unibarod, Yaoundé & $\begin{array}{l}\text { unibarod@yahoo.fr } \\
99614716918998079425024\end{array}$ & $25 / 11 / 09$ \\
\hline 70 & ADJONGO Come & $\begin{array}{l}\text { GIC Univers du Bambou et du Rotin } \\
\text { (Uni BaRo) }\end{array}$ & $\begin{array}{l}\text { Handicraft, unibarod@yahoo.fr } \\
996147 \text { 16, Bastos }\end{array}$ & $08 / 142 / 09$ \\
\hline 71 & $\begin{array}{l}\text { Micheal TCHANA } \\
\text { Paul MBOUI }\end{array}$ & Guiding Hope & guidinghope@yahoo.fr & 05/10/09 \\
\hline
\end{tabular}




\begin{tabular}{|c|c|c|c|c|}
\hline No & Name & $\begin{array}{l}\text { Organisation/ } \\
\text { Location }\end{array}$ & Contact/Email & Date \\
\hline 72 & Jean Michel ONANA & Herbier National du Cameroun & $\begin{array}{l}\text { (237) } 99743878 \\
\text { Jjmonana2002@yahoo.fr }\end{array}$ & 18/11/09 \\
\hline 73 & Dr. Alain MARLIAC & $\begin{array}{l}\text { Institue Recherche and } \\
\text { Développement IRD, Yaoundé }\end{array}$ & $\begin{array}{l}\text { Quartier Elig Essono, } 01 \text { B.P. 1857, } \\
\text { Yaoundé } \\
\text { Tél: (237) } 22015 \text { 08, Cameroun@ird.fr }\end{array}$ & $24 / 02 / 10$ \\
\hline 74 & Philip MOSOKA & Likombe & Bulleles, Likombe & $24 / 11 / 09$ \\
\hline 75 & IKOME Daniel & Likombe & Bricklayer, Likombe & 24/11/09 \\
\hline 76 & TOTE Lorance & Likombe & Farmer, Likombe & 24/11/09 \\
\hline 77 & Sako IDOGO & Likondje & Timber Dealer, Likondje & $24 / 11 / 09$ \\
\hline 78 & TANWI Eric & Limbe & Craftman, Limbe & $25 / 11 / 09$ \\
\hline 79 & Martin ATENDONG & Limbe & Handicraft, Limbe & 25/11/09 \\
\hline 80 & MOLONA Isaac & Lysoka & Securty offices, Lysoka & $24 / 11 / 09$ \\
\hline 81 & IOKER Elvis & Lysoka & Timber exploitation, Lysoka & $24 / 11 / 09$ \\
\hline 82 & YAMTEM John & Lysoka & Farmer, Lysoka & 24/11/09 \\
\hline 83 & Alain MUDUNJIE & Lysoka & Farmer, Lysoka & 24/11/09 \\
\hline 84 & NTSAMA Hubert & Marché Nkolouloun & $\begin{array}{l}\text { Collecteur, Marché Nkolouloun } \\
96424272\end{array}$ & $23 / 11 / 09$ \\
\hline 85 & WANDJO David & Marché Nkolouloun & $\begin{array}{l}\text { Collecteur, Marché Nkolouloun } \\
94888129\end{array}$ & $23 / 11 / 09$ \\
\hline 86 & WANDJA Michel & Melon & Agriculture, Melon & $30 / 11 / 09$ \\
\hline 87 & KINGOKO Joseph & Melon & Agriculture, Melon & $30 / 11 / 09$ \\
\hline 88 & TAGNE Brigitte & Melon & Agriculture, Melon & $30 / 11 / 09$ \\
\hline 89 & DJEMELI Paul & Melon & Agriculture, Melon & $30 / 11 / 09$ \\
\hline 90 & WAGUIA Michel & Melon & Agriculture, Melon & $30 / 11 / 09$ \\
\hline 91 & Damien PIAL & MinFoF & $\begin{array}{l}\text { Responsable de Poste de Djembe, } \\
\text { Lobeke }\end{array}$ & $26 / 02 / 10$ \\
\hline 92 & Paul WAMBA & MinFOF & paulwamba1@yahoo.fr & $\begin{array}{l}11 \text { and } 18 \\
/ 11 / 09\end{array}$ \\
\hline 93 & Jacques NYAM Eben & $\begin{array}{l}\text { Ministry Petites Moyens } \\
\text { Entreprises, Inspection General, } \\
\text { Yaoundé }\end{array}$ & 77691393 ebennyam@yahoo.fr & $25 / 11 / 09$ \\
\hline 94 & PA Isaac Tie & Muea & Craftman, Muea & $25 / 11 / 09$ \\
\hline 95 & AKUH Moses & Muea & Farmer, Muea & $23 / 11 / 09$ \\
\hline 96 & SUH John & Muea & Farming, Muea & 25/11/09 \\
\hline 97 & MBUA M. & Muea & Motor machine & $23 / 11 / 09$ \\
\hline 98 & BELINGA Jean Didier & Mvog-Mbi & Handicraft, Mvog-Mbi & 05/12/09 \\
\hline 99 & AMBASSA AMBASSA Denis & Mvog-Mbi & Handicraft, Mvog-Mbi 74449900 & $05 / 12 / 09$ \\
\hline 100 & FOUMANE & Mvog-Mbi & Handicraft, Mvog-Mbi 74392627 & 05/12/09 \\
\hline 101 & Pascaline, Angeline Njoutu & $\begin{array}{l}\text { North West Crafts Association } \\
\text { Bamenda }\end{array}$ & $\begin{array}{l}\text { nowecanet@yahoo.com } \\
\text { www.wagne.net/noweca/dossiers/ } \\
\text { http://www.cnac-cameroun.org/ }\end{array}$ & 05/10/09 \\
\hline 102 & CHESOGH George A. & Presscraft Bafut & Handicraft, Bafut & $14 / 12 / 09$ \\
\hline 103 & NGAH Frédérie & $\begin{array}{l}\text { Regroupement des Artisans } \\
\text { Vanniers }\end{array}$ & Handicraft, Tunnel Mboppi & 24/11/09 \\
\hline 104 & $\begin{array}{l}\text { Martin Cheek, Tom COPE, } \\
\text { Grace, Olwen }\end{array}$ & Royal Botanic Gardens Kew & M.Cheek@kew.org & $20 / 11 / 09$ \\
\hline 105 & TIEGUHONG Julius Chupezi & $\begin{array}{l}\text { Technical Training and Research } \\
\text { Centre for Development } \\
\text { (TTRECED), Yaoundé }\end{array}$ & chupezi@yahoo.co.uk & $01 / 11 / 09$ \\
\hline 106 & Marc PARREN & Tropenbos International, Cameroon & Marc.parren@yahoo.com & October 2009 \\
\hline
\end{tabular}




\begin{tabular}{lllll}
\hline No & Name & $\begin{array}{l}\text { Organisation/ } \\
\text { Location }\end{array}$ & Contact/Email & Date \\
\hline 107 & $\begin{array}{l}\text { NKWATOH, Athanasius } \\
\text { Fuashi }\end{array}$ & University of Buea & nkwatohaf@gmail.com & $21 / 11 / 09$ \\
108 & NGOUA Cyrille & University of Buea & Student, Muea & $25 / 11 / 09$ \\
109 & Felix MEUTCHIEYE & $\begin{array}{l}\text { University of Dschang, FASSA } \\
\text { Campus A }\end{array}$ & $\begin{array}{l}99901009 / 79679789 \text { meutche@ } \\
\text { yahoo.fr }\end{array}$ & $25 / 11 / 09$ \\
110 & ABANDA Marcel & Zamakoe & Handicraft, Zamakoe & $02 / 12 / 09$ \\
111 & ATANGANA Germain & Zamakoe & Handicraft, Zamakoe & $02 / 12 / 09$ \\
112 & NANGA ALOUA Ivan Bertran & Zamakoe & Handicraft, Zamakoe & $02 / 12 / 09$ \\
113 & MESSI Mathew & Zamakoe & Handicraft, Zamakoe & $02 / 12 / 09$ \\
114 & FOUDA Robert & Zamakoe & Handicraft, Zamakoe & $02 / 11 / 09$ \\
\hline
\end{tabular}




\section{Appendix 2. Questionnaires}

\section{Questionnaire for collectors (Urban and Rural)}

Questionnaire No.: Interviewed by

Region District. ..Village/town

Name of Respondent. Date of Interview

\section{Socio-demographic Information}

1. Age of respondent. Gender $\mathrm{M} / \mathrm{F}$

2. Educational status: Nil ( ) Primary ( ) Middle/JSS ( ) Secondary/SSS ( ) Polytechnic/Training college ( ) University ( ) Others

3. Ethnic origin: Native ( ) Migrant ( ) Settler ( ) Specify ethnic group

4. Major occupation Gross income

5. Minor occupation Gross income

6. Marital status: Single ( ) Married ( ) No. of spouses......, Divorced ( ) Widowed ( )

7. Household size... : Men $>15$ years Women $>15$ years

Children: boys $<15$ years girls $<15$ years

8. Number and gender of household members involved in Bamboo collection

Men. Women Children: boys girls.

9. Type of Bamboo collection activities household members engage in:

\begin{tabular}{|l|l|l|l|}
\hline Activity & Men & Women & Children \\
\hline Collection & & & \\
\hline Transportation & & & \\
\hline Marketing & & & \\
\hline Processing & & & \\
\hline
\end{tabular}

10. Gross income from Bamboo collection (per trip/week/month/annum)

11. Other sources of income (Please state and specify amount/month)

12. What is the approximate area or size of your community land you collect Bamboo from? 
13. What proportion of the community land is covered by Bamboo? $100 \%$ ( ) $>50 \%($ ) $33 \%()<33 \%($ )... Others

14. What proportion of the community land covered by Bamboo is harvested every year?

15. Who controls or owns the Bamboo land you exploit or work on? Chief ( ) Community ( ) Family ( ) Landowner ( ) Government ( ) No one ( )

16. Who has the right to harvest Bamboo? Natives only ( ) Any one at all ( )

17. How do you obtain the right or access to harvest the Bamboo?

18. Do you own any Bamboo area? Yes ( ) No ( )

(i) If yes, state the size of area owned

(ii) If no, how do you pay for the area harvested? Royalty ( ) Commission ( )

Tax ( ) Rent (....) bamboo produce ( ) Nothing ( )

(iii) How much do you pay per year?

(iv) To whom do you make the payment?

(v) What is your opinion of the level of payment?

(vi) If nothing is paid give reasons

19. How is the Bamboo stock locally regenerated?..a). natural ( ) (b) planted ( ) (c) both a and b ( )

20. What local regulations and practices are there for managing the available Bamboo stock?

21. Do you belong to any Bamboo association? Yes ( ) No ( )

(i) If yes, what type of Bamboo association? Collectors ( ) Processors ( ) Manufacturers ( )

Others

(ii) What is the main objective of this association?

(iii) Number of people belonging to the association?

(iv) Since when established?

(v) How long have you been a member?

(vi) Benefits gained or expected from the association? 


\section{Bamboo Collection}

22. Where do you or other members of the community normally collect Bamboo from?

Natural production forest ( ) Forest reserve ( ) fallow farm land ( ) Community land ( ) Others

23. What time of the year do you normally collect Bamboo? Dry season ( ) Rainy season ( )

All year round ( ) Please specify the months

24. How many months do you harvest Bamboo during the collection season?

25. Please state: (i) Number of trips in a month. (ii)Duration of a trip

26. How many bundles of Bamboo do you collect per trip/week/month?

27. What are the most common Bamboo species collected?. (

(

(

28. Which species do you prefer most? (

Why

29. What factors determine good quality Bamboo species?

30. How are you able to differentiate between species?

31. What is the average length of Bamboo collected?

32. List tools and other inputs required for Bamboo harvesting

33. Please describe the Bamboo harvesting process......

34. Do you know any sustainable harvesting method? Yes ( ) No (); If No, what technique do you think can be sustainable? 
35. How do you transport the harvested Bamboo? Vehicle ( ) Bike ( ) Head ( ) Truck ( ) Others

36. How far from your village is the Bamboo found?...Distance $(\mathrm{km}) \ldots . . . .$. Time (Minutes)

37. Where do you normally assemble the harvested Bamboo?

38. How far from the point of assembly is the Bamboo found $(\mathrm{km})$

39. How much do you spend per person in collecting Bamboo per trip?

40. What is the average number of people in a collection team?

41. Where do you obtain finance for Bamboo collection?

42. Do you sometimes reject Bamboo collected? Yes ( ) No ( )

(i) If yes, how much is rejected per trip?

(i) Give reasons for the rejection.

43. Do you sometimes use some of the Bamboo collected for household purposes? Yes ( ) No ( )

If yes, how much is used

Please state purpose(s)

44. What factors affect the volume of Bamboo harvested? Availability ( ) Harvesting technique ( )

Accessibility ( ) Season/time of year ( ) Level of disease infestation ( )

Labour availability ( )

Others

45. What kind of infestation do you normally see? Stain ( ) Insects ( ) Decay ( )

Others.

46. How do you treat the infestation?

47. What chemical(s) do you use for the treatment?

48. What problems do you face with Bamboo collection and How do you solve or think these problems can be solved?

\begin{tabular}{|l|l|}
\hline Problem & Solution \\
\hline & \\
\hline & \\
\hline & \\
\hline & \\
\hline & \\
\hline
\end{tabular}


49. List regulations/controls on Bamboo collection by government dept. or association

\section{Costs and Revenues}

50. Costs in Bamboo collection (per trip)

\begin{tabular}{|l|l|l|}
\hline Activity/ltem & \multirow{2}{*}{ Amount (FCFA) } \\
\cline { 1 - 2 } $\begin{array}{l}\text { Labour } \\
\text { No. of people per trip }\end{array}$ & & \\
\hline No. of trips per week & & \\
\cline { 1 - 2 } Expenses per trip (food and transport) & & \\
\hline Rent/Fee/Royalty/Commission/Access tax & \\
\hline Transportation (assembling point to market) & \\
\hline Tools & \\
\hline Marketing (expenses incurred in selling) & \\
\hline Other inputs & \\
\hline Other expenses & \\
\hline
\end{tabular}

51. Household Expenses (per week/month / year)

\begin{tabular}{|l|l|}
\hline Item & Amount (FCFA) \\
\hline Food & \\
\hline Clothing & \\
\hline Rent & \\
\hline School fees & \\
\hline Medical fee & \\
\hline Funerals & \\
\hline Entertainment & \\
\hline Other social expenses & \\
\hline Total & \\
\hline
\end{tabular}

52. Revenue from Bamboo collection (per trip)

\begin{tabular}{|l|l|l|l|}
\hline $\begin{array}{l}\text { Average bundles of Bamboo } \\
\text { collected per trip }\end{array}$ & $\begin{array}{l}\text { Av. No. of trips per day/week/ } \\
\text { month/year }\end{array}$ & $\begin{array}{l}\text { Selling price per } \\
\text { bundle }\end{array}$ & Total earned per year \\
\hline & & & \\
\hline & & & \\
\hline
\end{tabular}

53. Other Household Incomes (per month/year)

\begin{tabular}{|l|l|}
\hline Item & Amount (FCFA) \\
\hline Farm production & \\
\hline Trading & \\
\hline Government work & \\
\hline Labourer & \\
\hline Remittances & \\
\hline Livestock & \\
\hline Fishing & \\
\hline Hunting & \\
\hline Timber company work & \\
\hline Apprenticeship & \\
\hline Retired worker & \\
\hline
\end{tabular}




\section{Marketing of raw Bamboo}

54. Where do you sell the Bamboo harvested? *Please name town/village.

Home ( ) Local market ( ) Collection point ( ) Urban market ( )

Others

55. Who buys the Bamboo harvested? Processor ( ) Middle man ( ) Others

56. What is the purchasing arrangement? Cash payment ( ) Advanced payment ( ) Credit ( ) Barter ( )

57. Are you satisfied with the income you earn from Bamboo collection? Yes ( ) No ( ) reasons

58. Do you grade the raw Bamboo before sale? Yes ( ) No ( ) Why?

59. If yes, how is the grading done?

\section{Processing}

60. Do you carry out any processing activities on the raw Bamboo? Yes ( ) No ( ) If yes,

(i) Specify type of activities

(ii) Describe the process.

(iii) List tools and other inputs required for processing and their uses

\begin{tabular}{|l|l|}
\hline Tools / Inputs & Use \\
\hline & \\
\hline & \\
\hline & \\
\hline & \\
\hline & \\
\hline
\end{tabular}


61. Type of processing activities that household members are engaged in:

\begin{tabular}{|l|l|l|l|}
\hline Activity & Men & Women & Children \\
\hline & & & \\
\hline & & & \\
\hline & & & \\
\hline & & & \\
\hline
\end{tabular}

62. Please state quantity processed (per trip/day/week)

63. What product(s) do you produce?

64. Please list costs incurred in Bamboo processing

\begin{tabular}{|l|l|}
\hline Item & Cost/amount (FCFA) \\
\hline & \\
\hline & \\
\hline & \\
\hline & \\
\hline & \\
\hline
\end{tabular}

65. How much do you earn from the processed Bamboo?

\begin{tabular}{|l|l|l|}
\hline Product & Quantity sold per trip/day/week/month & Price/Amount (FCFA) \\
\hline & & \\
\hline & & \\
\hline & & \\
\hline & & \\
\hline
\end{tabular}

66. Who buys the processed Bamboo? Middleman( ) Wholesaler ( ) Retailer ()

Processor ( ) End user ( ) Others

Where do they come from?

67. Where do you sell the processed Bamboo? Name of town/village

68. What should be done to enhance the Bamboo industry in the country? 


\section{Questionnaire for Processors}

Questionnaire No.: Interviewed by

Region .District. Village/town

Name of Respondent

.Date of Interview

\section{A. Proprietor}

\section{Socio-demographic Information}

1. Age of respondent. Gender. $\mathrm{M} / \mathrm{F}$

2. Educational status: Nil ( ) Primary ( ) Middle/JSS ( ) Secondary/SSS ( )

Polytechnic/Training college ( ) University ( ) others

3. Ethnic origin: Native ( ) Migrant ( ) Settler ( ) Specify ethnic group (.... ..)

4. Major occupation. ...Gross income

5. Minor occupation. ... Gross income.

6. Marital status: Single ( ) Married ( ) No. of spouses ( ) Divorce ( ) Widowed ( )

7. Household size. Men $>15$ years Women $>15$ years

Children: boys $<15$ years. girls $<15$ years

8. Number and gender of household members involved in Bamboo processing:....

Men. Women. Children: boys. girls

9. Type of Bamboo processing activities household members engage in:

\begin{tabular}{|l|l|l|l|}
\hline Activity & Men & Women & Children \\
\hline Drying & & & \\
\hline Scraping & & & \\
\hline Bending/varnishing and fashioning & & & \\
\hline Marketing & & & \\
\hline
\end{tabular}

10. How did you enter the Bamboo processing business?

11. How long have you been in the enterprise?

12. Position in the enterprise: Owner ( ) Manager ( ) Chief apprentice ( )

Overseer/supervisor ( ) Others.

13. Is the enterprise registered?. With which organisation?

14. Are you a member of any Bamboo association? Yes ( ) No ( ) Name of association 
15. If yes, which type? Collectors ( ) Processors ( ) Traders ( ) Others

16. What is the objective of this association?

17. How many people belong to the association?

18. When was it established?

19. How long have you been a member?

20. What benefits have you derived or are you expecting from the association?

\section{Bamboo Processing}

21. Which of the following types/stages of Bamboo processing do you do?

(i) Primary processing: Cleaning ( ) Curing ( ) Fumigation ( )

(ii) Secondary processing: Scrapping ( ) Peeling ( ) Splitting ( ) Weaving/manufacture ( )

(iii) All of the above ( )

22. What Bamboo species do you process most?

Why?

Which other species do you use? (

23. Where do you get them from?

24. What factors determine good quality Bamboo species?

25. What Bamboo products do you produce, species used and respective volume of production

\begin{tabular}{|l|l|l|l|}
\hline Type of product & Bamboo species used & Source of Bamboo species used & $\begin{array}{l}\text { Quantity produced per day/week/ } \\
\text { month }\end{array}$ \\
\hline & & & \\
\hline & & & \\
\hline & & & \\
\hline & & & \\
\hline & & & \\
\hline
\end{tabular}




\begin{tabular}{|l|l|l|l|}
\hline & & & \\
\hline & & & \\
\hline & & & \\
\hline & & & \\
\hline
\end{tabular}

26. What problems do you encounter in processing Bamboo and how do you solve these problems?

\begin{tabular}{|l|l|}
\hline Problem & Solution \\
\hline & \\
\hline & \\
\hline & \\
\hline
\end{tabular}

27. List tools used in processing and uses

\begin{tabular}{|l|l|}
\hline Tool & Uses \\
\hline & \\
\hline & \\
\hline & \\
\hline & \\
\hline & \\
\hline & \\
\hline & \\
\hline
\end{tabular}

28. Describe how you process the Bamboo

29. Name common chemicals used in processing and for what purpose

\begin{tabular}{|l|l|}
\hline Chemical & Use/purpose \\
\hline Glue & \\
\hline Petrol & \\
\hline Lacquer & \\
\hline Vanish & \\
\hline Thinner & \\
\hline Others & \\
\hline & \\
\hline
\end{tabular}

30. What kind of waste is generated from processing?.

31. What do you do with the waste generated

32. Does the enterprise have any pressing need for technical assistance? Yes ( ) No ( )

33. If yes, what type of technical assistance?

34. Where do you get it from?

How much do you pay? 


\section{Marketing of processed Bamboo}

35. Do you grade processed Bamboo before sale? Yes ( ) No ( )

36. If yes what prices are paid for the various grades?

\begin{tabular}{|l|l|}
\hline Grade & Price \\
\hline & \\
\hline & \\
\hline & \\
\hline & \\
\hline
\end{tabular}

37. How is the grading done?

38. Where do you sell your products? Local market ( ) Road side ( ) Urban market ( ) Workshop ( )

Foreign/export market ( ) Others

39. Who buys your products? Middlemen ( ) Wholesalers ( ) Retailers ( )

Local end users ( ) Tourists ( ) Others.

40. Where do your clients come from and what quantity of products do they purchase? (tick as appropriate)

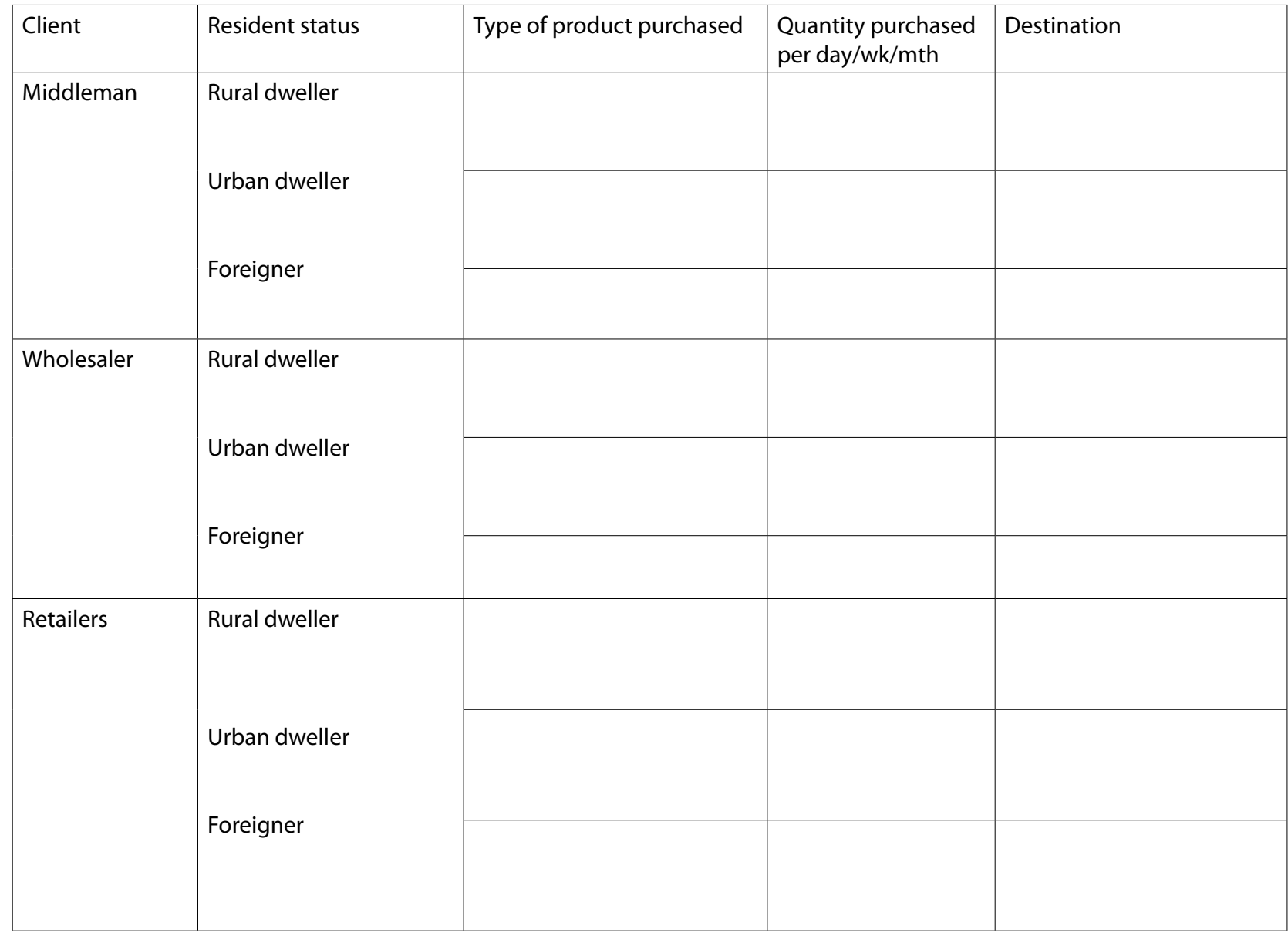




\begin{tabular}{|l|l|l|l|l|}
\hline End users & Rural dweller & & & \\
\cline { 3 - 5 } & Urban dweller & & & \\
\cline { 3 - 5 } & Foreigner/Tourist & & & \\
\cline { 3 - 5 } & & & & \\
\hline
\end{tabular}

41. Who sets the price for your products? Self ( ) Union/association ( ) Others

42. What is considered in price setting?

Quantity of material used ( ) Quality of material ( ) Size ( ) Beauty ( )

Type of product ( ) Market demand ( ) Cost of raw materials ( ) Others.

43. What problems do you encounter in marketing Bamboo products and how do you solve or think these problems could be solved?.

44. Cite major problems you face and how you think they can be solved

\begin{tabular}{|l|l|}
\hline Problem & Solution \\
\hline & \\
\hline & \\
\hline & \\
\hline & \\
\hline & \\
\hline & \\
\hline & \\
\hline & \\
\hline
\end{tabular}

\section{Employment}

45. Employment status (Please specify below)

\begin{tabular}{|l|l|l|l|}
\hline Status & Weeks available/month & Months available & Wage paid \\
\hline Full-time & & & \\
\hline Part-time & & & \\
\hline Sub-contract & & & \\
\hline Piece-wise & & & \\
\hline
\end{tabular}

46. Other fringe benefits (specify below)

\begin{tabular}{|l|l|l|l|l|l|}
\hline Status & Leave credits & $\begin{array}{l}\text { Productivity } \\
\text { bonus }\end{array}$ & Insurance & Health care & Other \\
\hline Full-time & & & & & \\
\hline Part-time & & & & & \\
\hline Sub-contract & & & & & \\
\hline Piece-wise & & & & & \\
\hline
\end{tabular}




\section{Inputs}

47. Material inputs

\begin{tabular}{|l|l|l|l|l|}
\hline Input & Source & $\begin{array}{l}\text { Quantity used per } \\
\text { wk/month }\end{array}$ & Unit price & Method of payment \\
\hline Bamboo & & & & \\
\hline $\begin{array}{l}\text { Chemicals } \\
\text { - Glue } \\
\text { Petrol } \\
\text { - Lacquer } \\
\text { - Vanish } \\
\text { - Thinner } \\
\text { - Others }\end{array}$ & & & & \\
\hline Plywood & & & & \\
\hline Gas & & & & \\
\hline Nails & & & & \\
\hline Others & & & & \\
\hline
\end{tabular}

48. Investment capital

\begin{tabular}{|l|l|l|l|}
\hline Amount of capital & Name of source & Interest rate & Repayment period \\
\hline & & & \\
\hline & & & \\
\hline & & & \\
\hline
\end{tabular}

\section{Costs and Revenues}

\section{Costs}

a. Costs in Bamboo processing

i) Raw materials

\begin{tabular}{|l|l|l|l|}
\hline Item & $\begin{array}{l}\text { Quantity purchased per week/ } \\
\text { month }\end{array}$ & Unit price & Amount \\
\hline Bamboo & & & \\
\hline $\begin{array}{l}\text { Chemicals } \\
\text { Glue } \\
\text { - Petrol } \\
\text { - Lacquer } \\
\text { - Vanish } \\
\text { - Thinner } \\
\text { - Others }\end{array}$ & & & \\
\hline Plywood & & & \\
\hline Gas & & & \\
\hline Nails & & & \\
\hline Others & & & \\
\hline
\end{tabular}


ii) Labour

\begin{tabular}{|l|l|l|}
\hline Labour category & Number & Wage rate / allowance (day/week/month) \\
\hline Apprentice & & \\
\hline Contract (daily/wkly/mthly/seasonal & & \\
\hline Overseer/supervisor & & \\
\hline Manager & & \\
\hline Others & & \\
\hline
\end{tabular}

iii) Equipment

\begin{tabular}{|l|l|l|l|l|}
\hline Equipment & Use(s) & Quantity & Unit price & Amount \\
\hline Knives & & & & \\
\hline Brushes & & & & \\
\hline Benches/tables & & & & \\
\hline Gas cylinder & & & & \\
\hline Gas blower & & & & \\
\hline Sprayer & & & & \\
\hline Others & & & & \\
\hline
\end{tabular}

iv) Miscellaneous

\begin{tabular}{|l|l|}
\hline Item & Amount (FCFA) \\
\hline Land/workshop rent & \\
\hline Transportation cost & \\
\hline Interest on loans & \\
\hline Overheads (maintenance, etc) & \\
\hline Taxes & \\
\hline Other fees/levies paid & \\
$\begin{array}{l}\text { Ticket } \\
\text { Association dues } \\
\text { Susu } \\
\text { Equipment rentals } \\
\text { Others }\end{array}$ & \\
\cline { 2 - 2 } & \\
\cline { 2 - 2 }
\end{tabular}

b. Household expenses (per month/year)

\begin{tabular}{|l|l|}
\hline Item & Amount (FCFA) \\
\hline Food & \\
\hline Clothing & \\
\hline Rent & \\
\hline School fees & \\
\hline Medicals & \\
\hline Funerals & \\
\hline Entertainment & \\
\hline Other social expenses & \\
\hline
\end{tabular}

50. Revenues

a. Revenue from Bamboo processing

\begin{tabular}{|l|l|}
\hline Product & Amount earned (per day/week/month) \\
\hline & \\
\hline & \\
\hline & \\
\hline & \\
\hline & \\
\hline
\end{tabular}


b. Other incomes

\begin{tabular}{|l|l|}
\hline Source & Amount (FCFA) \\
\hline Farm produce & \\
\hline Other trades/petty trading & \\
\hline Government work & \\
\hline Labourer & \\
\hline Remittances & \\
\hline Others & \\
\hline
\end{tabular}

51. Apart from women from your household, do you involve other women in the enterprise?

In what capacity?

52. How do women generally perform compared to their male counterparts?

53. Do you involve other children?

In what capacity?

54. State/list regulations and controls by government dept., association, etc on

(i) Acquisition of raw materials

(ii) Processing

(iii) Marketing of Bamboo products

55. What should be done to enhance the Bamboo industry in the country? 


\section{Questionnaire for Traders}

Questionnaire No.: Interviewed by

Region . District Village/town

Name of Respondent

Date of Interview

\section{Socio-demographic Information}

1. Age of Respondent.

Gender....

... $/ \mathrm{F}$

2. Educational status: Nil ( ) Primary ( ) Middle/JSS ( ) Secondary/SSS ()

Polytechnic/Training college ( ) University ( ) Others.

3. Ethnic origin: Native ( ) Migrant ( ) Settler ( ) Specify ethnic group (............)

4. Major occupation. Gross income.

5. Minor occupation. Gross income

6. Marital status: Single ( ) Married ( ) No. of spouses

7. Household size. Men $>15$ years Women $>15$ years

Children: boys $<15$ years. girls $<15$ years

8. Number and gender of household members involved in Bamboo processing:........ Men. Women. Children: boys. girls

9. Number and gender of other household members involved in Bamboo trade.

Men Women ..Children: Boys. Girls.

10. Type of bamboo trading activities that household members are engaged in.

\begin{tabular}{|l|l|l|l|}
\hline Activity & Men & Women & Children \\
\hline Transportation & & & \\
\hline Exhibition & & & \\
\hline Selling & & & \\
\hline Others & & & \\
\hline
\end{tabular}

11. Are you a member of any Bamboo association? Yes ( ) No ( )

12. If yes, name the association

13. What is the objective of this association? 
14. How many people belong to the association?

15. When was it established?

16. How long have you been a member?

17. What benefits have you derived or are you expecting from the association?

\section{Bamboo Trading}

18. What category of Bamboo traders do you belong to?

a) Unprocessed/Raw Bamboo: Middleman ( ) Wholesaler ( ) Retailer ( ) Others

b) Processed Bamboo: Middleman ( ) Wholesaler ( ) Retailer ( ) Others.

c) Finished Bamboo products: Middleman ( ) Wholesaler ( ) Retailer ( ) Others

19. What Bamboo products do you trade in?

20. Which species do you prefer most?

Why?

21. What factors determine good quality Bamboo species?

22. Where do you sell your goods? Roadside ( ) Market ( ) Home ( ) Store ( )

Others.

23. Who buy(s) your goods?

24. How is the price fixed?

25. What factors control prices of your goods? 
26. Please specify quantities traded on local and export markets

\begin{tabular}{|l|l|l|l|l|}
\hline Product & Local Market & \multicolumn{2}{|l|}{ Foreign/Export Market } \\
\cline { 2 - 5 } & $\begin{array}{l}\text { Quantity traded per } \\
\text { day/week/month }\end{array}$ & Price per unit & $\begin{array}{l}\text { Quantity traded per day } \\
\text { week/month }\end{array}$ & Price per unit \\
\hline & & & & \\
\hline & & & & \\
\hline & & & & \\
\hline & & & & \\
\hline & & & & \\
\hline
\end{tabular}

27. Clients and Average quantities of goods purchased?

\begin{tabular}{|l|l|l|l|l|l|l|}
\hline Client & Goods traded & $\begin{array}{l}\text { Location/ } \\
\text { destination }\end{array}$ & $\begin{array}{l}\text { Quantity } \\
\text { purchased per } \\
\text { day/wk/mth }\end{array}$ & Unit price & Marketing costs & $\begin{array}{l}\text { Marketing } \\
\text { arrangements }\end{array}$ \\
\hline Wholesaler & & & & & & \\
\hline & & & & & & \\
\hline & & & & & & \\
\hline Retailer & & & & & & \\
\hline & & & & & & \\
\hline & & & & & & \\
\hline & & & & & & \\
\hline End-user & & & & & & \\
\hline & & & & & & \\
\hline
\end{tabular}

${ }^{* *}$ Client $=$ the person who purchases the raw Bamboo or processed Bamboo or finished product from the trader ** Market arrangement $=$ whether goods (i) Supplied on contract (ii) Anytime available (iii) Transported to client (iv) Client purchases at source or market (v) Payment made in advance (vi) Payment made at time of purchase (vii) Payment made later Others.......

28. What problems do you encounter in Bamboo trading and how do you solve or think these problems could be solved? (Quels problèmes vous rencontrez dans le commerce bambou et comment vous résolvez ou pensez qu'ils pourraient être résolus)

\begin{tabular}{|l|l|}
\hline Problem & Solution \\
\hline & \\
\hline & \\
\hline & \\
\hline & \\
\hline & \\
\hline & \\
\hline
\end{tabular}

29. How do you see the market in the future? (Please explain) 
What rules and regulations affect the trade? (Règles et loi qui affectent le commerce du Bambou)

a) Government (e.g. Forestry Dept, Metropolitan assembly, Export Promotion council etc)

b) Non-governmental (e.g. Association, clubs, etc)

\section{Costs and Revenues}

30. Bamboo trading costs (Coûts de la marchandise de bambou)

\begin{tabular}{|l|l|}
\hline Item & Amount (FCFA) \\
\hline Goods purchased (per day/week/month) & \\
\hline Transportation of goods & \\
\hline Government taxes/levies/market tolls & \\
\hline Store/stall rent & \\
\hline Association dues & \\
\hline Susu (daily/weekly/monthly savings) & \\
\hline Others & \\
\hline
\end{tabular}

31. Household Expenses (per month / year) (Dépenses de ménage (par mois/année))

\begin{tabular}{|l|l|}
\hline Item & Amount (FCFA) \\
\hline Food & \\
\hline Clothing & \\
\hline House rent & \\
\hline School fees & \\
\hline Medical fee & \\
\hline Funerals & \\
\hline Entertainment & \\
\hline Other social expenses & \\
\hline
\end{tabular}

32. Revenue from Bamboo trade (Revenu du commerce en bambou)

\begin{tabular}{|l|l|}
\hline Goods/products & Amount earned per day/wk/month \\
\hline & \\
\hline & \\
\hline & \\
\hline & \\
\hline & \\
\hline
\end{tabular}


33. Other Incomes (per day/week/ month/year)

\begin{tabular}{|l|l|}
\hline Item & Amount (FCFA) \\
\hline Farm production & \\
\hline Trade in other goods** & \\
\hline Government work & \\
\hline Labourer & \\
\hline Remittances & \\
\hline Livestock & \\
\hline Fishing & \\
\hline Others & \\
\hline
\end{tabular}

** State other goods traded.

Énoncez d'autres marchandises commercialisées

39. What should be done to enhance the Bamboo industry in the country?

Que devrait être fait pour améliorer l'industrie en bambou dans le pays ? 


\section{Questionnaire for consumers of bamboo products}

1. Quels produits (meuble) de bambou avez — vous acheté ces derniers jours?

Which bamboo products have you purchased these days?

2. Quel produit de bambou utilisez-vous dans votre ménage ?

Which bamboo product does your household use?.
a. Furniture (chairs, tables, beds...)
b. Fencing
c. Supports
d. TV antennal posts
e. Decking storey buildings
f. Fuelwood
g. Roofing houses
h. Food
i. Electric posts
j. Handicarft (utencils, woven materials)
k. Others (please, specify)

3. Vous utilisez le bambou pour faire quoi?

What do you use the bamboo for?

4. Comparez-vous les produits issus du bambou avec d'autres produits?

Do you compare the products from bamboo with other products?

5. En terme de qualité?

In terms of quality?

6. En terme de prix?

In terms of price?

7. En terme de résistance (durée de vie de l'outil)?

In terms of resistance (lifespan of the tool)?

8. En terme d'attraction sur la clientèle?

In terms of attraction on the customers?

9. Avez-vous le sentiment que le montant que vous payez, est proportionnel à la qualité du produit reçu? [Oui]

[Non]: 
Do you have the feeling that the amount you pay is proportional to the product quality received? Yes ( ) No ( )

10. Sinon expliquez SVP:

If No please explain:

11. Quels autres produits aimeriez-vous voir fabriquer à base du bambou?

Please, list other bamboo products you would like to see being manufactured?

12. En tant que consommateur, quelle amélioration dans la transformation du bambou pourrait conduire à des bénéfices substantiels?

As a consumer, what improvement in the transformation of bamboo is needed? 


\section{Appendix 3. Terms of Reference}

\section{Aim}

Study of Production to Consumption System (PCS) of bamboo in Cameroon

Conduct a study of the Production to Consumption System (PCS) of bamboo in Cameroon that will include determination and analysis of:

a. The types, quantity and quality of bamboo resources and their production

b. Sustainability of current management and harvesting practices

c. Primary and secondary processing practices and technologies undertaken

d. Types of products produced and their markets

e. Infrastructures, bodies and processes for transportation and commercialisation

f. Stakeholders involved at all levels of the production chain, from farmers to consumers of the final products and the benefits they get from it.

g. Policy environment, rules, regulations and their effectiveness

h. Constraints and opportunities for livelihood development of small holders and microenterprises and the development of a set of practical recommendations for improvement of the sector.

\section{Timescale}

By 31 December 2008

\section{Methodology and activities}

1. Literature review of PCS of bamboo in Cameroon

2. Preliminary work;

a. Identification of key study areas: At least three provinces of Cameroon shall be visited for this study with major markets and production zones identified, Tentatively, provinces under consideration include: Southwest, Centre, South, Littoral, West and Northwest.

b. Development of questionnaire

c. Elaboration of field work plan and budget to CIFOR

3. Elaboration of a draft Table of Contents (using the Ghana PCS as a guide)

4. Field work: visits to key sites for observation and interview questionnaires (focus groups and individuals)

5. Consultation meetings with stakeholders (communities, government, local administration, craftspeople etc)

6. Consultation with national level stakeholders (MinFoF, ANAFOR, National Cameroon crafts organisation - Le Corps National des Artisans du Cameroun (CNAC) etc)

7. Data inputting (Excel/SPSS) and analysis

8. Reporting

9. Incorporation of comments

10. Final Report

\section{Output Verifications}

- List of site visits made, stakeholders interviewed and focus group meetings with date/place and number of attendants and key contacts (provided as Annex in the Report)

- Guideline interview questionnaires developed (focus groups and individuals) in consultation with CIFOR team leader

- Map of main PCS locations and flows (using GPS),

- Diagrams of PCS with actors, types, quantities and volumes

- Photos from field site visits

- Copy of SPSS database 


This study is part of the INBAR and World Agroforestry Centre project 'Enhancing opportunities for market-led bamboo-based development in West and Central Africa' from 2008-2009, financed by the Common Fund for Commodities. The project produced studies of the bamboo production to consumption systems in Cameroon, Ghana, Nigeria, Sierra Leone and Togo. The findings were presented at a regional workshop in Yaoundé, 23-25 November 2009, to develop national and regional actionable recommendations for market-led, bamboo-based development in the region. 